\title{
AVALIAÇÃO ECOFISIOLÓGICA DO CAFEEIRO (Coffea arabica L.) EM SISTEMA AGROFLORESTAL E EM MONOCULTIVO
}

\section{Ciro Abbud Righi}

Tese apresentada à Escola Superior de Agricultura "Luiz de Queiroz", Universidade de São Paulo, para obtenção do título de Doutor em Agronomia, Área de Concentração: Fitotecnia.

P I R A C I C A B A

Estado de São Paulo - Brasil

Abril - 2005 


\section{AVALIAÇÃO ECOFISIOLÓGICA DO CAFEEIRO (Coffea arabica L.) EM SISTEMA AGROFLORESTAL E EM MONOCULTIVO}

\section{Ciro AbBud Righi}

Engenheiro Agrônomo

Orientador: Prof. Dr. MARCOS SILVEIRA BERNARDES

Tese apresentada à Escola Superior de Agricultura

"Luiz de Queiroz", Universidade de São Paulo, para obtenção do título de Doutor em Agronomia, Área de Concentração: Fitotecnia.

P I R A C I C A B A

Estado de São Paulo - Brasil

Abril - 2005 
Dados Internacionais de Catalogação na Publicação (CIP) DIVISÃO DE BIBLIOTECA E DOCUMENTAÇÃO - ESALQ/USP

\section{Righi, Ciro Abbud}

Avaliação ecofisiológica do cafeeiro (Coffea arabica L.) em sistema agroflorestal e em monocultivo / Ciro Abbud Righi. - - Piracicaba, 2005.

101 p. : il.

Tese (doutorado) - - Escola Superior de Agricultura Luiz de Queiroz, 2005. Bibliografia.

1. Café 2. Ecofisiologia 3. Luz 4. Matéria seca 5. Seringueira 6. Sistema agroflorestal 7. Transpiração vegetal I. Título

CDD 633.73 


\section{AGRADECIMENTOS}

Ao Prof. Dr. Marcos Silveira Bernardes, pela oportunidade de realização do doutorado, orientação e visão crítica dos SAFs e do meio científico.

Ao Prof. Dr. Chin K. Ong; pela orientação e pela oportunidade de intercâmbio e a Janet Awimbo, Jan Benieste, Azene Bekele e toda equipe do ICRAF em Nairobi/Quênia pela calorosa recepção, convívio, discussões e oportunidade de participação nas diversas atividades.

A equipe do RELMA (Regional Land Management) e GWP (Global Water Paternship) pelo apoio e convívio, em especial a Naomi Njeri, Alex Oduor, Peter e a Maimbo Malesu pela oportunidade de ir ao centro de origem do cafeeiro na Etiópia.

Ao Prof. Dr. José Dias Costa, pela paciência, calma e sábios conselhos sobre o caminho a ser tomado, muito auxiliando minhas decisões.

A Alessandra de Oliveira pela pessoa que é.

A Alessandra Maria Elias, que sempre, mesmo longe, estava presente e a seu irmão Tico pelas viagens ao redor do mundo e crença nas coisas boas da vida.

A Leonardo Médici pela ajuda nas análises estatísticas e a Carlos Rodrigues Pereira pelas discussões e partidas de xadrez.

Aos colegas e amigos Edson Roberto Teramoto, Luis Fernando Guedes Pinto, Leila Sobral Sampaio, Aureny M. P. Lunz, Flávio M. P. Costa e demais colegas de pósgraduação.

A Marcos Gennaro (Braxola), Rodrigo Uchoa Fagundes Ferraz de Camargo (Ema), Fábio Câmara Bueno (Step), Luiz Fernando Artimonte Vaz (Kmões), André Luis Beoso Junqueira de Andrade ( $\pi$ nókio), Maximiliano Miura (Gavião) e toda minha república Xapadão pelo sempre apoio e amparo nas horas mais difíceis.

A todos os Professores da ESALQ/USP e em especial aos do Dept ${ }^{\circ}$. de Produção Vegetal pela oportunidade de aprendizado e apoio no esclarecimento de dúvidas e aulas ministradas. Também aos Profs. do Dept ${ }^{\circ}$. de Agrometeorologia, em especial, Profs. Drs. Nilson A. Villa Nova, Luiz Roberto Angelocci, Sérgio Moraes, Antonio R. Pereira e Quirjn de Jong van Lier pelas inúmeras discussões e auxílios. 
A Fabiana Taveira de Camargo e sua mãe pelas correções de português.

A Luciane A. L. Toledo, secretária da pós-graduação em fitotecnia pela atenção e sorriso.

Aos funcionários do Dept ${ }^{0}$. de Produção Vegetal pelo apoio incansável na implantação e condução do experimento.

A FAPESP, pela concessão da bolsa de doutorado e pelo apoio financeiro ao experimento e demais participações em congressos e reuniões científicas.

A todos aqueles que de alguma forma, direta ou indiretamente, contribuíram para a realização deste trabalho. 
Às pessoas que sabem rir e a meu pai que dava gargalhadas. A minha mãe, Lourdes Abbud Righi com sua visão afiada, a meus irmãos, Alex, Bruno, Dario e Adne e a todos de minha família

"Um dos paradoxos dolorosos do nosso tempo reside no facto de serem os estúpidos os que têm uma certeza, enquanto os que possuem imaginação e inteligência se debatem em dúvidas e indecisões."

A última oportunidade do homem Bertrand Russell, 1990 ( $3^{\circ}$ ed.)

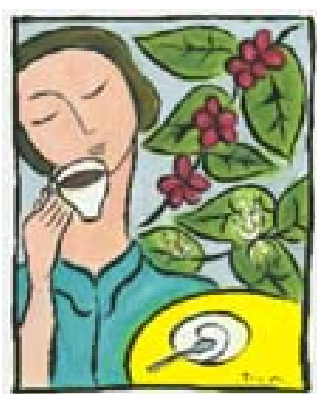

Mulher bebendo café 


\section{SUMÁRIO}

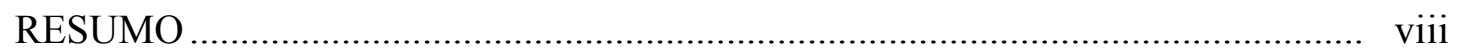

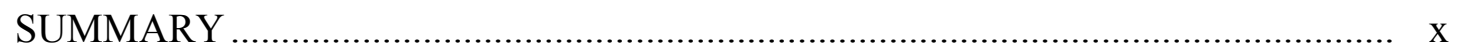

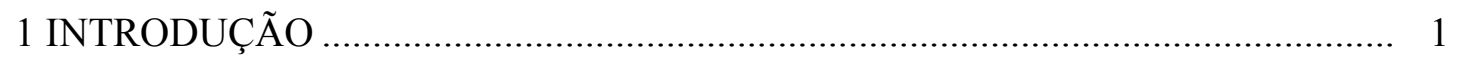

2 REVISÃO DE LITERATURA ……......................................................... 3

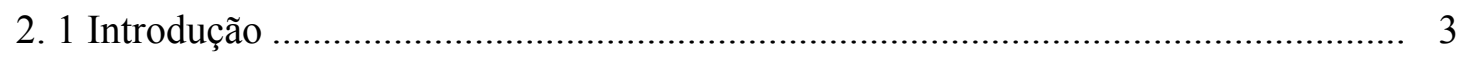

2. 2 Alguns aspectos microclimáticos e o cafeeiro .................................................. 4

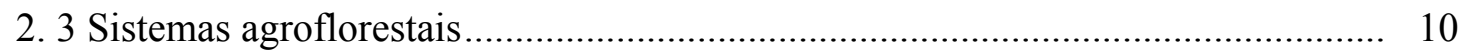

2. 4 Modelagem e simulação.................................................................................... 19

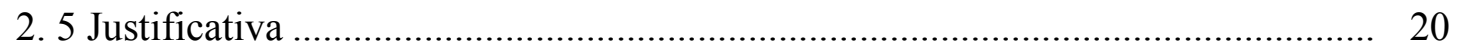

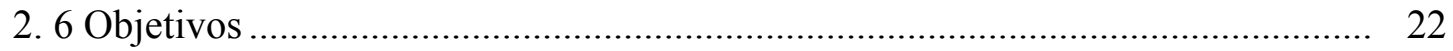

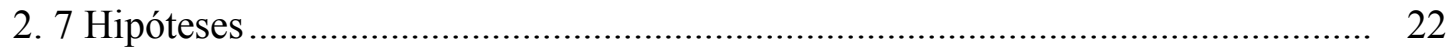

2. 8 Material e Métodos .......................................................................................... 22

2. 8. 1 Local da realização do experimento............................................................ 22

2. 8. 2 Características do solo.............................................................................. 23

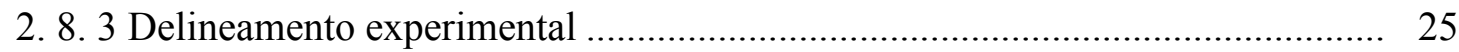

2. 8. 4 Instalação e manejo das culturas ....................................................................... 27

2. 8. 5 Determinação experimental dos parâmetros analisados .................................. 28

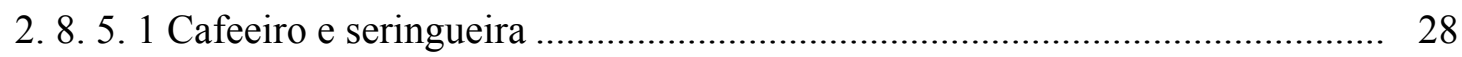

2. 8. 5. 2 Medidas microclimáticas ...................................................................... 31

2. 8. 5.3 Modelo matemático................................................................................ 34

2. 9 Forma de Análise dos Resultados ..................................................................... 34

3 SIMULAÇÃO E DISPONIBILIDADE DE LUZ E CRESCIMENTO DE CAFEEIROS EM SISTEMA AGROFLORESTAL COM SERINGUEIRAS ........... 35 


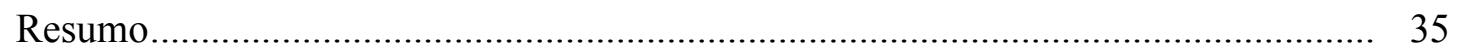

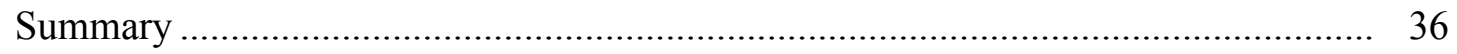

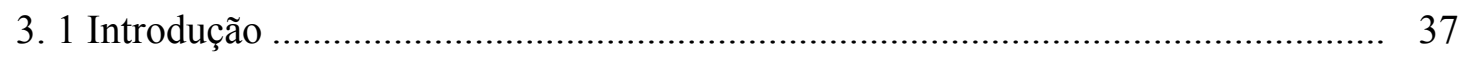

3. 2 Material e Métodos ….................................................................................. 41

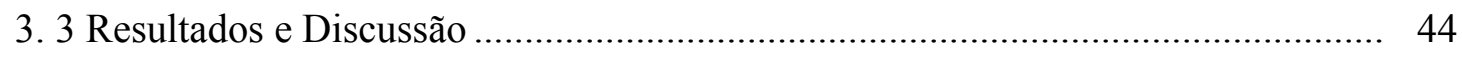

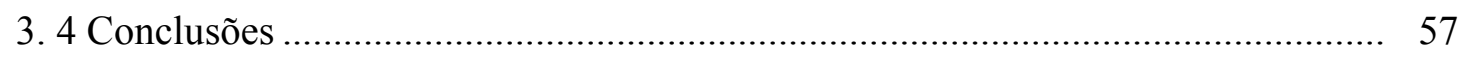

3. 4. 1 Considerações Finais............................................................................. 57

4 USO DA ÁGUA POR CAFEEIROS EM UM SISTEMA AGROFLORESTAL COM

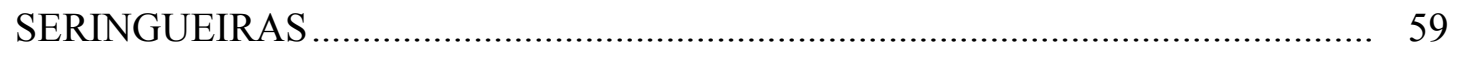

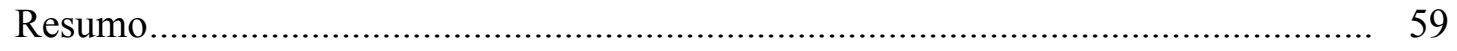

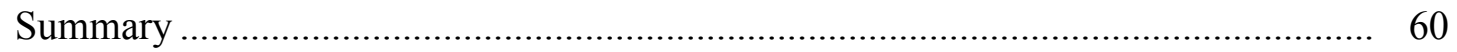

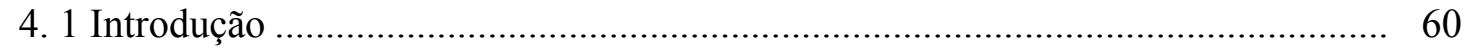

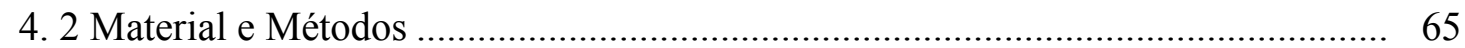

4. 3 Resultados e Discussão ………....................................................................... 67

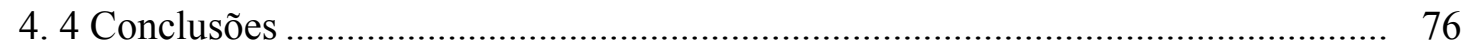

4. 4. 1 Considerações Finais................................................................................ 76

5 PROBLEMAS NA UTILIZAÇÃO DO MÉTODO DE BALANÇO DE CALOR NAS DETERMINAÇÕES DE FLUXO DE SEIVA EM SERINGUEIRAS (Hevea brasiliensis MÜELL. ARG.) E CAFEEIROS (Coffea arabica L.)............................................... 77

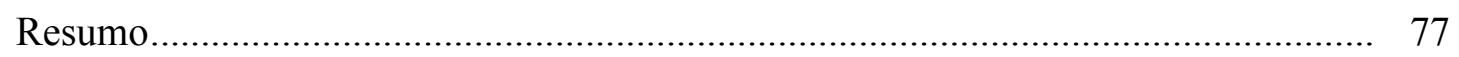

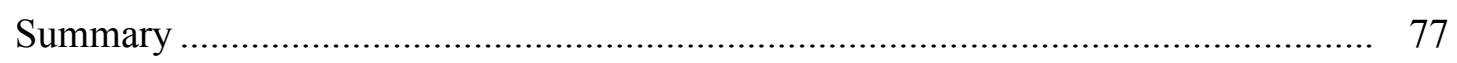

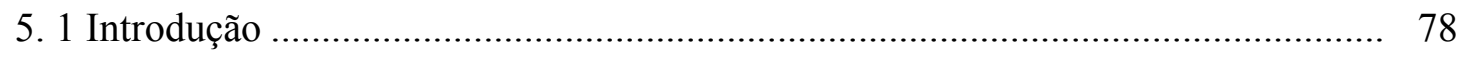

5. 2 Material e Métodos .................................................................................. 78

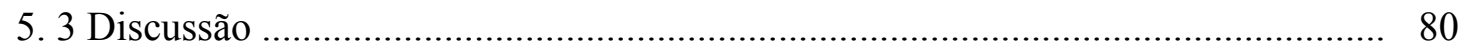

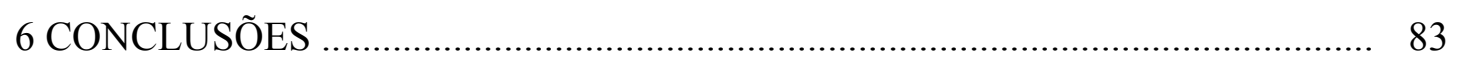

6. 1 Considerações finais e sugestões para futuros trabalhos...................................... 84

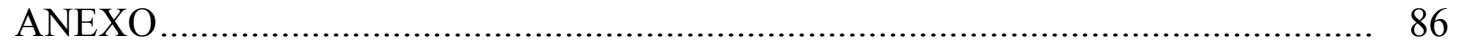

REFERÊNCIAS BIBLIOGRÁFICAS ........................................................... 88 


\section{AVALIAÇÃO ECOFISIOLÓGICA DO CAFEEIRO (Coffea arabica L.) EM SISTEMA AGROFLORESTAL E EM MONOCULTIVO.}

Autor: CIRO ABBUD RIGHI

Orientador: Prof. Dr. MARCOS SILVEIRA BERNARDES

\section{RESUMO}

O presente trabalho objetivou uma melhor compreensão do comportamento ecofisiológico do cafeeiro (Coffea arabica L.) sob diferentes condições de cultivo sejam, intensidade de sombra e demais interações com a seringueira (Hevea brasiliensis Müell. Arg.). Procurou-se evidenciar a competição por luz e água em função da distância das árvores e conseqüente diferente intensidade de competição. As hipóteses desse trabalho são: 1. A redução da disponibilidade de luz pelas árvores afeta o crescimento dos cafeeiros positivamente pela redução da transpiração e negativamente pela redução da fotossíntese líquida expressa como acúmulo de matéria seca da parte aérea; 2. Existe competição por luz entre o cafeeiro e a árvore sombreadora, sendo esta proporcional à distância entre as culturas e ao tamanho da árvore sombreadora; 3. O modelo matemático utilizado descreve adequadamente a disponibilidade de luz à cultura intercalar e pode ser uma importante ferramenta no desenho de sistemas agroflorestais (SAFs). O experimento foi instalado no campo experimental do Dept. de Produção Vegetal da Escola Superior de Agricultura "Luiz de Queiroz" - ESALQ/USP em Piracicaba-SP $\left(22^{\circ} 42^{\prime} 30^{\prime \prime} \mathrm{S}, 4^{\circ} 38^{\prime} 00^{\prime \prime} \mathrm{W}\right.$ - altitude $\left.554 \mathrm{~m}\right)$ num delineamento em faixas (Strip-Plot), onde a distância do cafeeiro em relação às árvores define um tratamento, com níveis de interações entre as culturas a depender desta variável. De acordo com os dados experimentais obtidos pôde-se concluir que: 1. No intervalo entre 
100 a 45\% da irradiância disponível não houve redução no acúmulo de matéria seca dos cafeeiros. Maiores reduções da irradiância disponível levaram à diminuição do acúmulo de matéria seca diretamente proporcional, bem como modificações em suas características morfológicas e fisiológicas dada à adaptação a estas condições; 2. O sombreamento teve um efeito positivo na redução da transpiração por unidade de área foliar e por planta. Por outro lado teve um efeito negativo aumentando a transpiração por unidade de irradiância disponível; 3. O modelo matemático proposto por Goudriaan (1977) simulou bem a disponibilidade de irradiância à cultura intercalar, com boa aproximação entre os valores medidos e estimados. Assim, sua disponibilidade está relacionada com a distância e tamanho das árvores sombreadoras.

Palavras-chave: café; ecofisiologia; sistema agroflorestal; seringueira; transpiração; matéria seca, luz 


\section{ECOPHYSIOLOGICAL EVALUATION OF COFFEE PLANTS (Coffea arabica L.) IN AN AGROFORESTRY SYSTEM AND IN MONOCROP}

Author: CIRO ABBUD RIGHI

Adviser: Prof. Dr. MARCos SilveIRA BERNARDES

\section{SUMMARY}

The main objective of the present work was the better understanding of the ecophysiological interactions within rubber trees (Hevea brasiliensis Müell. Arg.) and coffee plants (Coffea arabica L.). Above and below ground interactions were analyzed as a function of tree distance and consequent competition intensity. The main hypotheses of this research were: 1. Reduction on light availability due to trees affects the coffee plant growth positively by the transpiration reduction and negatively by the net photosynthesis reduction expressed by dry matter accumulation; 2. There are light competition between coffee plants and shade trees, been this proportional to the distance among crops and tree size; 3. The mathematical model used described adequately the light availability to the associated crop and can be an important tool on agroforestry system (AFS) design. The experiment was established in an experimental field belonging to the Dept. of Plant Production - ESALQ/USP at Piracicaba-Brazil $\left(22^{\circ} 42^{\prime} 30^{\prime \prime} \mathrm{S}, 47^{\circ} 38^{\prime} 00^{\prime \prime} \mathrm{W}\right.$ - altitude 554m) in random blocks with 11 treatments in a "Strip-Plot" design, where interactions intensity between crops were determined by the distances of the coffee plants to the tree. According to the experimental data obtained it was possible to concluded: 1 . In the interval of 100 to $45 \%$ available irradiance coffee plants did not showed reduction on dry matter accumulation. Further reductions on available irradiance led to reduction on dry matter accumulation directly proportional, as 
well as to modifications on morphological and physiological characteristics due to its adaptation to these conditions; 2 . Shade had a positive effect reducing transpiration per unit of leaf area and per plant. On the other hand had a negative effect rising the transpiration per unit of available irradiance; 3. The mathematical model proposed by Goudriaan (1977) presented a good simulation of the available irradiance to the associated crop, with good approximation between measured and simulated values. So, it availability is related to the distance and size of the shade trees.

Key-words: coffee, eco-physiology, agroforestry, rubber tree, transpiration, dry matter, light 


\section{INTRODUÇÃO}

O café é o segundo produto mais exportado pelo Brasil e representa alto percentual da receita do país. A cultura do cafeeiro foi foco de pesquisa por muito tempo, dada a sua importância sócio-econômica. Os estudos com esta rubiácea porém, foram conduzidos no sentido de obter genótipos mais produtivos e que propiciassem uma melhor bebida em cafezais em sistema de monocultivo. No país poucos foram os trabalhos desenvolvidos com cafeeiro em sistema agroflorestal (SAF). Regiões, antes consideradas como marginais ou inaptas para a cafeicultura, devido as alta irradiâncias e temperaturas, vêm sendo apontadas como promissoras para seu cultivo, onde o uso de árvores de sombra poderá ser uma técnica promissora. Os SAFs podem propiciar maior eficiência e complementaridade espacial e temporal no uso dos recursos disponíveis à produção, seja da água, nutrientes, etc. A redução da densidade de plantio das árvores sombreadoras ou o consórcio com plantas tolerantes ao sombreamento e mais competitivas por água e nutrientes podem elevar a eficiência dos SAFs. Estes ainda, podem promover uma diversidade de culturas nas áreas agrícolas incrementando a sustentabilidade na produção. A utilização de SAF pela cafeicultura pode representar o avanço desta cultura no país por aumentar a estabilidade de produção da planta, seja pela redução do estresse e conseqüente esgotamento à que está submetido o cafeeiro a pleno sol, seja pelas condições microclimáticas mais apropriadas.

Este estudo visa ampliar o entendimento dos efeitos causados pela modificação das condições microclimáticas pela utilização do SAF, em comparação com as culturas solteiras, bem como avaliar o desempenho do sistema. Dados fitométricos e microclimáticos foram coletados por meio da utilização de estações 
micrometeorológicas. A transpiração dos cafeeiros também foi medida procurando-se relacioná-la com a irradiância disponível e aspectos anatômicos e micrometeorológicos. Os resultados ainda foram utilizados para avaliar um modelo matemático de interceptação de luz. Visou-se com isso contribuir para o entendimento das intrincadas relações existentes em uma comunidade vegetal. 


\section{REVISÃO DE LITERATURA}

\section{1 Introdução}

A cultura do cafeeiro é de grande importância na economia mundial, em especial de países em desenvolvimento, onde sua renda é responsável pela manutenção de cerca de 25 milhões de famílias rurais em todo o mundo (International Coffee Organization ICO, 2004). O Brasil ocupa posição de destaque na produção mundial, sendo o maior produtor e exportador, com cerca de um terço do café produzido (Costa $\left.{ }^{1}\right)$. O café é um produto muito vulnerável às flutuações de preço no mercado (Caixeta, 2001; FNP, 2004). Nos últimos anos houve queda nos preços sendo que em 2002 o preço real pago aos produtores foi o menor em 100 anos, que receberam somente cerca de $2 \%$ do preço final do cafezinho das bancas européias. Portanto, a diversificação da produção pode ser uma importante estratégia para manter o equilíbrio econômico da propriedade (International Coffee Organization - ICO, 2004).

O café arábica (Coffea arabica L.) é originário de áreas elevadas do sul da Etiópia, próximas à linha equatorial, em latitudes variáveis de 6 a $9^{\circ} \mathrm{N}$ e longitudes 34 a $40^{\circ} \mathrm{E}$, onde cresce permanentemente sob sombreamento em habitat de floresta tropical. Nesta região o cafeeiro é encontrado em estado espontâneo e cultivado comercialmente em altiplanos entre 1400 e 1800 m com uma estação seca definida de 3 a 4 meses e precipitações pluviais anuais entre 1200 a 2000 mm bem distribuídas durante o restante do ano (Krug, 1959 e Kumar, 1979).

\footnotetext{
${ }^{1}$ Costa, J.D. - comunicação pessoal, 2005
} 
As plantações comerciais de café encontram-se distribuídas desde Cuba em latitude de $22^{\circ} \mathrm{N}$ até o Estado do Paraná-Brasil em latitude de $26^{\circ} \mathrm{S}$, cultivadas em diversas localidades do globo terrestre (Evanoff, 1994). Via de regra, o cafeeiro é conduzido sob sombra nas principais regiões produtoras do mundo, exceto no Brasil e no Quênia, numa tentativa de atenuar os efeitos adversos diretos e indiretos da alta irradiância (da Matta et al., 1999). No Brasil, o cafeeiro é cultivado economicamente sobretudo a pleno sol. Em países como a Colômbia pode-se encontrar culturas sombreadas com maior freqüência. A prática do cultivo do cafeeiro a pleno sol tem apresentado problemas como a super produção e o conseqüente esgotamento das plantas durante os primeiros anos, até que o auto-sombreamento diminua esse efeito (Voltan et al., 1992).

O clima seco favorece a colheita e a secagem dos grãos de café, não os sujeitando à umidade excessiva e a fermentações prolongadas que prejudicam a qualidade da bebida. (Reis, 1972 e Camargo, 1966).

A associação de cafeeiros com espécies arbóreas pode significar uma diversificação da fonte de renda do produtor, além de apresentar outros benefícios tais como: proteção contra geadas, redução da bienalidade e portanto maior estabilidade da produção, redução da incidência de plantas daninhas, de bicho mineiro (Campoe et al., 2003a e b), e da seca dos ponteiros, etc (Lunz et al., 2004).

Segundo Evanoff (1994), o ciclo de vida do cafeeiro está dividido em 3 grandes períodos: o primeiro - de crescimento, que vai da germinação à maturidade sexual, o segundo refere-se à produção e o terceiro e último é o da decadência fisiológica que termina com a morte do arbusto. Cada uma das fases é influenciada, em maior ou menor grau, por fatores ambientais como temperatura, radiação, precipitação e características do solo.

\section{2 Alguns aspectos microclimáticos e o cafeeiro}

Usualmente os parâmetros adotados nos mapeamentos de aptidão climática baseiam-se em elementos encontrados nas áreas de origem da espécie. No caso do 
cafeeiro os parâmetros climáticos dos altiplanos da Etiópia são indicadores das suas exigências específicas. No seu centro de origem, o café arábica está submetido a temperaturas amenas que variam de 18 a $22{ }^{\circ} \mathrm{C}$ (Camargo 1985). Este autor compôs uma carta de aptidão da cultura do cafeeiro baseada basicamente em temperatura e déficit hídrico anual para o café arábica e robusta.

A característica mais importante das plantas é sua habilidade para interceptar e absorver energia solar, utilizando-a para fixar o $\mathrm{CO}_{2}$ em um composto estável. Este processo é responsável pela captura e armazenamento de energia na biosfera. O saldo de $\mathrm{CO}_{2}$ fixado pela planta, ou fotossíntese líquida $\left(\mathrm{P}_{\mathrm{n}}\right)$, é a diferença entre a taxa de fixação bruta $\left(\mathrm{P}_{\mathrm{g}}\right)$ e a taxa de perda de $\mathrm{CO}_{2}$ durante o processo respiratório (R) (Jones, 1994). Nos vários tipos de vegetação encontrados na natureza, a produtividade está intimamente relacionada com a água disponível para as plantas (Salisbury e Ross, 1978). Dentre os vários fatores limitantes da produção vegetal, o déficit hídrico ocupa posição de destaque, pois além de afetar diretamente as relações hídricas nas plantas, alterandolhes o metabolismo, é fenômeno que ocorre em grandes extensões de áreas cultiváveis. Segundo Boyer (1982), as plantas podem ter desenvolvido mecanismos que diminuem os efeitos da falta de água no solo, capazes de serem transmitidos geneticamente. Entretanto, Mazzafera \& Carvalho (1987) observaram que é importante correlacionar a produtividade dos cafeeiros com condições de deficiência hídrica, uma vez que, muitas progênies tolerantes à seca apresentam baixas produções.

A medida da transpiração constitui-se num elemento essencial na compreensão da fisiologia das árvores e de sua dinâmica na transferência de água em comunidades florestais (Granier, 1985). Além disso, esse processo desempenha importante papel no balanço energético da planta com o meio e a absorção de dióxido de carbono para a fotossíntese (Angelocci, 2002).

A temperatura de uma planta varia com a radiação, transpiração, convecção e condução térmica (Gates, 1965). Linacre (1964) comparando diferentes culturas, verificou que existe uma tendência para a igualdade entre a temperatura do ar e das folhas ao redor de $33{ }^{\circ} \mathrm{C}$. Em temperaturas inferiores, as folhas apresentam-se mais aquecidas que o ar e nas superiores elas tendem a serem mais frias. 
A exposição direta das folhas à radiação solar, faz com que sua temperatura seja elevada intensificando a diferença de pressão de vapor entre o ar e o mesófilo foliar o que resulta em taxas mais elevadas de transpiração que por sua vez tem um papel termoregulador (Sutcliffe, 1980). Nos cafeeiros sombreados, as folhas apresentam-se mais frias o que resulta em menor transpiração (Morais et al., 2003).

A determinação do fluxo de água no xilema tem merecido grande atenção, principalmente em árvores cuja medição em campo sempre é difícil. Alguns métodos utilizam marcadores radioativos ou corantes, outros são baseados no fornecimento de calor e sua dissipação. Dentre estes últimos, podemos utilizar uma das três técnicas já empregadas com sucesso na determinação dos fluxos de seiva: (1) Método do Pulso de Calor - medição da velocidade de dissipação de um pulso de calor fornecido ao caule ou ramo transportador de seiva (Huber, 1932 e Huber \& Schmidt, 1937); (2) Método do Balanço de Calor - balanceamento do calor dissipado em um certo volume de caule ou ramo através do fluxo contínuo e constante de calor (Sakuratani, 1981; Valancogne \& Nasr, 1989 e Weibel \& Vos, 1994) e; (3) Método da Sonda de Calor ou Método de Granier - medição da dissipação do calor aplicado internamente ao tronco (Granier, 1985 e 1987).

A fotossíntese das folhas do cafeeiro não é afetada por potenciais hídricos de até $-1,0 \mathrm{MPa}$, reduzindo-se em 25\% quando o potencial cai para -2,0 MPa. Por outro lado, mesmo com o solo estando na capacidade de campo, nas horas mais quentes do dia o potencial hídrico foliar pode alcançar valores próximos de $-1,5 \mathrm{MPa}$, não diferindo muito de solos com 50\% de água disponível. Pode-se concluir que não há necessidade de irrigar o cafeeiro enquanto o teor de água no solo não alcançar a metade da capacidade de campo. Isso sugere que o cafeeiro é uma espécie relativamente resistente à seca (Mazzafera \& Carvalho 1987).

A estrutura da folha pode ser grandemente modificada pela intensidade de radiação disponível à planta durante sua fase de crescimento. A maior disponibilidade de luz proporciona aumentos na espessura da folha, na massa foliar específica, no desenvolvimento da epiderme e do parênquima e no número total de células das folhas (Esau, 1977). Fahl (1989) verificou a maior espessura e densidade de células em folhas 
de cafeeiro desenvolvidas a pleno sol. Aparentemente este mecanismo de adaptação também ocorre em outras plantas, tendo sido observado em feijoeiros por Righi (2000) uma diminuição da Área Foliar Específica (AFE) com o aumento da irradiação.

Com o crescimento do dossel, não somente são modificadas as condições ambientais, como também a estrutura física do mesmo, a idade das folhas e a distribuição dos fotoassimilados entre as diversas partes da planta. Essas mudanças alteram a eficiência com que a luz é capturada e utilizada pelos vegetais (Costa et al., 1999).

Curvas de resposta à luz têm sido apresentada, para diferentes espécies e para espécies particularmente aclimatadas em diferentes irradiâncias (Jones, 1994; Pachepsky et al., 1996). Embora a fotossíntese líquida $\left(\mathrm{P}_{\mathrm{n}}\right)$ nas espécies $\mathrm{C}_{4}$ apresentarem uma leve tendência de aumento maior do que nas espécies $\mathrm{C}_{3}$ devido a incrementos da irradiância, há grandes diferenças entre as espécies de sombra e de sol, ou entre folhas de uma mesma espécie crescendo sob diferentes irradiâncias. Nas espécies de sombra ou em folhas sombreadas, $\mathrm{P}_{\mathrm{n}}$ pode saturar a menos de $100 \mu \mathrm{mol} \mathrm{m} \mathrm{m}^{-2} \mathrm{~s}^{-1}$ de PAR, o que representa aproximadamente $5 \%$ da luz total. Folhas de sol, por outro lado, freqüentemente continuam a incrementar a $\mathrm{P}_{\mathrm{n}}$ com aumentos da irradiância até aproximadamente $1 / 3$ de sua disponibilidade num dia claro de verão na zona tropical. $\mathrm{O}$ ponto de compensação lumínica varia a partir de valores tão baixos quanto $0,5-2 \mu$ mol $\mathrm{m}^{-2} \mathrm{~s}^{-1}$, nas espécies de sombra, até valores de $40 \mu \mathrm{mol} \mathrm{m} \mathrm{m}^{-2} \mathrm{~s}^{-1}$ nas folhas de sol (Jones, 1994).

Diversos fatores contribuem para as diferenças existentes no comportamento fotossintético das folhas de sombra e de sol. Há evidências satisfatórias de que todos os componentes do sistema fotossintético adaptam-se juntos. Por exemplo, na presença de alta irradiância, as folhas tendem a ser mais espessas, com uma área de superfície interna maior que as folhas de sombra, ter mais clorofila e muito mais carboxilase, por unidade de área. Como a resistência do mesófilo, por unidade de superfície de célula, é aproximadamente constante, esta tende a diminuir com o aumento da irradiância, como resultado da mudança na razão entre a área de superfície da célula do mesófilo e a área de superfície da folha (Holmgren, 1968; Nobel et al., 1975), bem como ocorre na 
resistência estomática. As reações de luz também são afetadas pela irradiância crescente, ocorrendo o desenvolvimento de granas mais extensivos nas folhas de sombra, enquanto a capacidade para transporte de elétrons é marcadamente reduzida. Por exemplo, o transporte de elétrons nos dois sistemas, quando expresso numa base de clorofila, pode ser até 14 vezes mais intenso em cloroplastos extraídos de plantas de sol do que aquele verificado em cloroplastos extraídos de plantas sombreadas (Boardman et al., 1975; Boardman, 1977). Parte desse efeito pode resultar de uma leve diminuição no tamanho da unidade fotossintética. Os componentes da cadeia de transporte de elétrons, isto é, citocromo $\mathrm{f}$ e citocromo $\mathrm{b}$, são particularmente reduzidos nas plantas com baixa luminosidade. As várias adaptações, em resposta a irradiância alterada, podem ocorrer poucos dias após a mudança no ambiente (Malkin \& Fork, 1981).

Apesar da grande diferença na $P_{n}$ saturada por luz, somente pequenas diferenças têm sido observadas na inclinação inicial da curva de resposta da fotossíntese à luz. A recíproca desta inclinação, requerimento de quantum (quanta por $\mathrm{CO}_{2}$ fixado), é uma medida da eficiência da fotossíntese e é relativamente constante com um valor em torno de 19 para plantas $C_{4}$, enquanto nas plantas $C_{3}$ é fortemente dependente da temperatura e concentração de oxigênio (Ehleringer \& Björkman, 1977).

A ocorrência de irradiância elevada pode danificar o sistema fotossintético, particularmente de folhas adaptadas à sombra, ou de folhas nas quais o metabolismo fotossintético tenha sido inibido por outros estresses, tais como temperaturas extremas, ou estresse hídrico. Os danos podem ser um resultado de foto-oxidação onde ocorre destruição da clorofila. Quando não ocorre destruição da clorofila, mas o dano é observado, diz-se que ocorreu foto-inibição. A taxa respiratória também pode ser influenciada pela irradiância crescente, sendo tão baixa quanto $4 \mu \mathrm{g} \mathrm{m}^{-2} \mathrm{~s}^{-1}$ nas plantas de sombra e $50-150 \mu \mathrm{g} \mathrm{m}^{-2} \mathrm{~s}^{-1}$ em folhas de sol. Esta diferença pode contribuir para a vantagem no saldo fotossintético em baixa luminosidade, que é freqüentemente observado em folhas sombreadas (Jones, 1994).

Voltan et al. (1992) em estudo da epiderme de cafeeiros submetidos a diferentes disponibilidades de luz observaram que o número de estômatos decresceu linearmente com a irradiância. Deste modo o número de estômatos por $\mathrm{mm}^{2}$ decresceu em média 
cerca de 20 a $40 \%$ nas folhas de plantas cultivadas a 50 e $30 \%$ da luz solar total, respectivamente. As dimensões dos estômatos não foram afetadas significativamente pela variação dos níveis de luz.

Alvim (1960), analisando a variação da taxa fotossintética e condutância estomática em Coffea arabica a pleno sol e a sombra, observou que a condutância estomática, bem como a fotossíntese líquida, foram superiores no cafeeiro sombreado do que no a pleno sol. Cannell (1976) em experimento na Costa Rica e Fahl et al. (1994) e Carelli et al. (1999) encontraram que a fotossíntese dos cafeeiros sombreados é menor do que a de cafeeiros cultivados a pleno sol. Ainda, Nutman (1937a) e Kumar \& Tieszen (1980a) observaram menor atividade fotossintética em cafeeiros expostos a plena radiação solar no Quênia. Estes autores detectaram que a assimilação total diária foi maior à sombra do que ao sol. Medições da taxa fotossintética em cafeeiro variam desde $0,7 \mathrm{mg} \mathrm{CO} 2 \cdot \mathrm{dm}^{-2} \cdot \mathrm{h}^{-1}$ em condições de campo, até $16,0 \mathrm{mg} \mathrm{CO} 2 \cdot \mathrm{dm}^{-2} \cdot \mathrm{h}^{-1}$ em condições controladas. O Coffea canephora possui taxas de fixação de $\mathrm{CO}_{2}$ geralmente inferiores às do Coffea arabica, havendo alguma variação genética entre os cultivares. Isso poderá indicar-nos qual a variedade de café mais apta à utilização em SAFs.

Normalmente, o sombreamento provoca nos cafeeiros a redução do número de estômatos, da espessura do mesófilo foliar e num aumento dos espaços intracelulares (Voltan et al., 1992), sendo que tais características estão estreita e negativamente relacionadas com o processo de fotossíntese (Morais et al., 2003).

As copas das plantas têm um papel importante no crescimento e na produtividade. A arquitetura da copa das plantas é muito importante, pois define o tipo de distribuição de seus galhos e folhas, interferindo no modo de interceptação e aproveitamento da radiação disponível (Bernardes, 1987). A eficiência fotossintética de uma copa é afetada pela taxa fotossintética por unidade de área foliar e pela forma como a radiação solar é interceptada. A interceptação da radiação depende das características da copa, como sua arquitetura e dimensão. O índice de área foliar (IAF) e a duração da área foliar são os fatores mais importantes na determinação da produção de matéria seca e conseqüentemente do crescimento (Bernardes et al., 1996). 
Para Durigan (1987), a Grevillea robusta é a árvore que mais se aproxima do ideal para sua utilização como quebra-vento, por ser esta perenifólia, de crescimento rápido, pouco agressiva na competição radicular e de copa não muito densa. Entretanto, esta autora observou que pode haver competição por água próximo às árvores, até a distância igual à altura destas. Nessa faixa, o solo fica comparativamente mais seco, causando ainda, perdas ao cafeeiro adicionais àquelas devidas ao excesso de sombreamento.

Os quebra-ventos agem diretamente sobre o ambiente de 3 formas: 1) sombreando parcial e temporariamente a cultura protegida; 2) competindo por água e nutrientes do solo e; 3) diminuindo a velocidade do vento. Desta maneira, há modificações no microclima que por sua vez induzem alterações nos processos fisiológicos e nas características da cultura protegida (Leal, 1986).

\section{3 Sistemas agroflorestais}

Já em 1919 Cook $^{2}$ (citado por Rizzini \& Heringer, 1962) apontava o uso de SAFs nas regiões tropicais ao afirmar: "Ao invés de formar pastos artificiais e desertos, um ideal para a agricultura tropical é o desenvolvimento de florestas artificiais que, não somente irão fornecer comida e outros produtos úteis, mas ao mesmo tempo manter ou aumentar a fertilidade do solo."

Sistema Agroflorestal é um sistema de uso da terra no qual árvores crescem em associação com outras culturas perenes ou anuais e/ou gado, em várias disposições em espaço e tempo, utilizando práticas de manejo compatíveis com a população local. Neste sistema há interações ecológicas e econômicas entre as árvores e as outras culturas que resultam em algumas vantagens comparativas aos outros sistemas de agricultura (Nair, 1989; Young, 1989; Rao \& MacDiken 1991). Com a instalação das árvores na área com espaçamento convencional há, inicialmente, abundância de luz, umidade e nutrientes no solo, podendo as culturas intercalares desenvolverem-se de modo satisfatório, até que tais fatores de crescimento tornem-se limitantes (Bernardes, 1993).

\footnotetext{
${ }^{2}$ Cook, O.F. Annual report of the Smithsonian Institution. Smithsonian Institution. EUA, 1919. 325 p.
} 
Para Sanchez (1995), o desenvolvimento da agrofloresta como ciência deve basear-se em quatro aspectos: i) interação entre seus componentes por luz, água e nutrientes (pode ser negativa-competitiva ou positiva-complementar); ii) complexidade (ecológica e socioeconômica); iii) lucratividade (produção e mercado) e iv) sustentabilidade (conservação dos recursos naturais como biodiversidade, solos, recursos hídricos e carbono). Para Jha (1995) um SAF eficiente deveria ser conduzido a um desenvolvimento sistemático e integrado do sistema de uso da terra e práticas onde as interações positivas entre árvores e culturas fossem encorajadas e maximizadas.

Anderson \& Sinclair (1993) ressaltam que as interações ecológicas em SAFs dependem basicamente de fatores espaciais e temporais dos sistemas e da análise dos recursos limitantes ao crescimento vegetal. Para estes autores é importante separar a competição acima e abaixo do solo pelos recursos, possibilitando a redução da competição através da diferenciação de nichos ecológicos, onde as árvores e as culturas explorariam de maneira diferenciada os recursos disponíveis.

As interações biofísicas acima e abaixo do solo em sistemas agroflorestais (SAFs) determinam a partilha e a eficiência do uso de recursos por culturas e árvores, influenciando no crescimento e na produção das plantas (Ong et al., 1991). As interações podem ser de natureza competitiva ou complementar no uso de radiação solar, água e nutrientes, e o recurso mais limitante será definido pela combinação das características das plantas, clima, solo e manejo do sistema (Rao et al., 1997). Além disso, as interações podem alterar a alocação de recursos nas plantas, afetando o índice de colheita e a produção (Huxley, 1999).

Em condições de campo, as culturas estão sujeitas à influência de diversos elementos climáticos que, em constantes interações entre si e com outros fatores ambientais e fisiológicos, são determinantes para o crescimento e desenvolvimento dessas culturas. As interações entre as culturas e o ambiente envolvem processos físicos, químicos e biológicos, cujo estudo e compreensão são extremamente complexos (Chang, 1968). Um método simples e eficaz para avaliar as interações é medir a produção ao longo de uma transeção na interface árvore-cultura, especialmente em condições de campo onde é difícil encontrar interfaces controladas (Ong et al. 1996). 
A água constitui, aproximadamente, $90 \%$ da massa da planta, atuando praticamente em todos os seus processos físiológicos e bioquímicos. Desempenha a função de solvente, através do qual os gases, minerais e outros solutos entram nas células e movem-se através da planta. Tem, ainda, papel importante na regulação térmica da planta, agindo tanto no resfriamento através do processo de evapotranspiração como na manutenção e distribuição do calor (Nobel, 1980).

Assim, a precipitação é um dos elementos meteorológicos de grande importância para esta cultura, uma vez que sua ausência ou excesso, dependendo da fase fenológica na qual ocorra, poderá implicar em prejuízos, tanto no acúmulo de matéria seca (crescimento) quanto na produtividade e qualidade dos grãos (Hunter \& Erickson, 1952; Sionit \& Kramer, 1977).

A captura e uso dos recursos biofísicos pelas plantas de um dado SAF é determinada pela natureza e intensidade das interações entre seus componentes. O efeito destas interações é geralmente determinado pela influência do componente arbóreo nos demais ou no sistema como um todo, e é expresso em função de respostas quantificáveis (Rao et al., 1997). Segundo estes autores, o estudo das interações em agrofloresta requer a análise de diversos processos complexos, mas pode ser simplificado se estas forem classificadas de acordo com os fatores que são mais afetados como: fertilidade do solo (inclui interações químicas, físicas e biológicas); competição (envolve interações por água e nutrientes do solo, radiação e fatores microclimáticos); doenças e pragas; conservação do solo e alelopatia. Assim, muitas das interações e seus efeitos são interdependentes, não podendo ser analisados isoladamente e têm importâncias relativas a depender da estrutura do SAF (Bernardes, 1993).

Ong et al. (1996) são claros ao afirmarem que é preciso um estudo científico estruturado para análise quantitativa das interações árvore-cultura de maneira a: i) fornecer um método para determinar quais benefícios podem ser esperados em cada situação; ii) avaliar a importância relativa de cada interação; iii) quantificar vantagens de SAFs não somente em produção, mas quanto a outros benefícios ambientais.

A presença de árvores em um sistema de produção pode alterar o balanço de radiação e o comportamento de ventos na área sob influência destas. O efeito múltiplo 
destas mudanças no microclima modifica o balanço de energia disponível para o meio, acarretando mudanças no uso da água, na produtividade e ciclo das plantas sob esta condição (Monteith et al., 1991; Brenner, 1996).

A interação entre as plantas componentes dos SAFs e a atmosfera pode, de modo geral, ser avaliada em termos micrometeorológicos pelos seguintes elementos: 1) interceptação da radiação pela folhagem, que é um fator dominante na produção de biomassa; 2) interceptação da chuva pela folhagem, que interfere na oferta de água ao solo; 3) déficit de pressão de vapor d'água, que está diretamente relacionado à transpiração e; 4) temperatura que determina a taxa de desenvolvimento por estar relacionada à velocidade das reações bioquímicas (Sá, 1994).

O menor crescimento da cultura nas posições mais próximas das árvores deve-se a interações biofísicas abaixo e acima do solo entre ambas, em acordo com Rao et al. (1997). A presença das copas das árvores, e seu conseqüente sombreamento, reduzem a disponibilidade de radiação para a cultura e causa uma diminuição na temperatura do ar e do solo, quanto mais se aproxima destas (Monteith et al., 1991). Segundo Brenner (1996), o efeito da sombra e da alteração da temperatura e da umidade do solo e do ar, sobre a partição de assimilados, o desenvolvimento da planta e o índice de colheita, varia entre espécies, geralmente favorecendo as culturas em que se colhe folhas em detrimento de grãos.

Monteith et al. (1991) obteve, em média, para diversas culturas, o acúmulo de matéria seca a uma taxa de 1,4 g.MJ ${ }^{-1}$ de radiação global interceptada. Vários trabalhos, com o objetivo de analisar a relação entre radiação interceptada e matéria seca produzida, confirmaram que a fitomassa das culturas é efetivamente proporcional à quantidade de radiação interceptada pelo dossel. Tem-se demonstrado esta relação para diferentes culturas como, por exemplo, a soja (Shibles \& Weber, 1965, Bernardes et al., 1998b), o milho (Williams et al., 1965), o algodão (Baker \& Meyer, 1966) e o feijão (Righi, 2000). Segundo Black \& Ong (2000) o acúmulo de biomassa pode ser linearmente relacionado com a interceptação de radiação solar pelo dossel da cultura, sendo a última determinada pelo IAF (Loomis e Connor, 1992). Pinto (2002) confirmou 
tais resultados encontrando correlações altamente significativas entre matéria seca e IAF em cana-de-açúcar.

Fisiologistas e ecologistas há muito argumentam que o entendimento dos processos e mecanismos envolvidos na captura dos recursos e seu uso, e das suas interações com o ambiente é de fundamental importância para o desenvolvimento de sistemas produtivos mais sustentáveis (Willey \& Reddy, 1981; Ong et al., 1996).

Ocorrem variações drásticas na distribuição dos componentes da radiação direta e difusa, da radiação global, e sua participação em diferentes níveis de dosséis multiestratificados, em dias claros e em dias nublados, conforme foi verificado em uma associação de árvores sombreadoras de café por Baldy \& Stigter $^{3}$ (citados por Sá, 1994).

A eficiência de uso da radiação (EUR) pode ser definida como a quantidade de matéria seca produzida (g) por luz interceptada (MJ) (Muchow et al., 1993). Estimativas da EUR para diversas culturas crescendo com adequados níveis de água e nutrientes no solo têm sido relatadas como permanecendo constantes durante todo o ciclo de crescimento (Monteith, 1972; Gallagher \& Biscoe, 1978; Scott \& Wilcockson, 1978; Sinclair, 1991; Confalone et al., 1997). No entanto, outros estudos revelam que a EUR varia de acordo com as condições ambientais (Muchow et al., 1993), como foi demonstrado com a temperatura (Andrade et al., 1993), radiação (Russell et al., 1989) e deficiência de pressão de vapor (Squire, 1990; Stockle \& Kiniry, 1990).

Franco $^{4}$ (citado por Camargo, 1985) relata que o sombreamento dos cafezais no sudeste do Brasil data talvez, da introdução da espécie no país. Porém, essa técnica não se generalizou, o que foi atribuído ao fato da baixa produção do cafeeiro ser resultante da concorrência por água das árvores de sombra.

Analisando todos os fatores em SAF de milho com árvores de grande porte, como a castanha negra (Juglans nigra) e carvalho vermelho (Quercus rubra), Gillespie et al. (2000) verificaram que a água era fator mais limitante que luz para o desempenho do sistema. Huxley (1999) apontou que tanto as características de manejo como as

\footnotetext{
${ }^{3}$ BALDY, C.; STIGTER, C.J. Agrométéorologie des cultures multiples en régions chaudes.. Paris; INRA, 1993. $246 \mathrm{p}$.

${ }^{4}$ FRANCO, C.M. Fotoperiodísmo em cafeeiro (Coffea arabica L.) Revista do Instituto do Café. v.. 27, n. 164, p. 1556-1592. 1963.
} 
biológicas das árvores (copa, sistema radicular e demanda por água) determinam a intensidade das interações e o desempenho das culturas associadas.

Ong et al. (1996) relatam que as interações abaixo do solo têm-se mostrado importantes em SAFs. Desde que SAFs envolvem mistura de espécies, estas devem compartilhar de muitos processos em comum, incluindo competição, modificação ambiental, transferência de nitrogênio às não leguminosas associadas, e especial atenção deve ser dada aos estudos de eficiência da utilização dos recursos naturais. Segundo Sá (1994), os sistemas agroflorestais proporcionam grande melhoria no uso da água com disponibilidade sazonal em regiões semi-áridas e nos trópicos áridos. A maioria dos sistemas de culturas anuais usa somente 30 a 35\% da água da chuva, pois muita dela é perdida por evaporação do solo, escorrimento superficial, ou é perdida em umidade residual no final da colheita. SAFs oferecem a oportunidade de complementaridade espacial e temporal no uso da água, o que pode resultar em melhor aproveitamento desta, comparativamente às culturas solteiras (Ong et al. 1996).

Ao que tudo indica, não há qualquer benefício às culturas intercalares devido à melhoria das condições micrometeorológicas, como redução das temperaturas máximas, aumento da umidade relativa do ar, redução de ventos, etc. nas regiões tropicais úmidas (Nuberg et al., 2002). Exemplos de rendimento nas culturas intercalares não sendo reduzidos por competição com as árvores ocorrem em áreas recebendo grandes quantidades de chuva (Crawford et al., 1998). Vários autores (Kang, 1993; Sanchez, 1995; Govindarajan, et al., 1996 e Stirzaker et al., 2002) apontam que em ambientes com limitações de disponibilidade de água, SAFs em renques tendem a ter efeito negativo na produção de grãos das culturas associadas mais freqüentemente do que um efeito neutro ou positivo. Ong (1994) aponta que o foco na utilização de SAFs em renques deveria ser portanto em minimizar os efeitos negativos ao invés de procurar súbitos aumentos de produção.

Bernardes \& Fancelli (1990) avaliaram o cultivo de seringueira intercalar ao citrus e afirmaram que praticamente todo o Planalto Paulista (exceto as regiões de elevada altitude) é preferencial para a heveicultura. Os autores também indicam que além de possuir dossel fechado, a seringueira apresenta um denso e extenso sistema 
radicular na superfície do solo; fatores que contribuem para a conservação do mesmo. Para Young, 1989 e Baumer, 1990 agroecossistemas com culturas perenes apresentam um alto grau de estabilidade devido à proteção do solo e manutenção da fertilidade, aumentando a sustentabilidade do sistema.

Segundo Young (1997b), sistemas de multiestratos e cultivo em aléias em contorno (contourhedgerow) são os principais tipos de SAFs para controlar erosão e escoamento superficial em regiões declivosas. SAFs apropriados têm o potencial de controlar a erosão, manter a matéria orgânica do solo e suas propriedades físicas, aumentar a fixação de nitrogênio e promover uma eficiente ciclagem de nutrientes. McDonald et al. (1997) definiram aléias em contorno como o cultivo de aléias em forma de uma barreira ao longo dos contornos do terreno em declive, com as faixas entre as aléias usadas para produção das culturas.

Confirmando o potencial da utilização com sucesso de aléias em contorno na região de Piracicaba, Fujisaka (1997) revisou diversas experiências internacionais onde este sistema foi adotado e sintetizou as situações onde faz sentido seu emprego: a) em climas úmidos e sub-úmidos, podendo combinar controle da erosão com cultivo agrícola em declives amenos a moderados; b) onde os solos são relativamente produtivos e a erosão é limitante à produção; c) situações onde o tamanho da população local é incompatível com o uso extensivo da terra.

De acordo com Jha (1995) a conservação do solo inclui a aplicação da ciência agronômica, florestal e da engenharia. Reynolds et al. (1988) afirma que em áreas acidentadas, quando árvores leguminosas são plantadas em contorno, estas limitam a erosão. Singh \& Singh (1980) apontaram que entre todos os sistemas de cultivo, a maior perda de solo é observada em áreas utilizando agricultura rotacional e que a menor perda registrada foi em uma floresta de bambu em Meghalaya/Índia.

Segundo Jha (1995), para aumentar e conservar a umidade do solo, medidas devem ser tomadas para elevar a taxa de infiltração e diminuir a evaporação do solo, sendo que alguns modelos de SAFs podem ser mais eficientes. SAFs mantém a terra quase que continuamente recoberta, assim melhora a taxa de infiltração do solo, reduz a erosão e constrói sua fertilidade. Além disso, a cultura intercalar ou a folhagem das 
árvores pode ser utilizada como cobertura-morta, que atua como barreira superficial, evita a evaporação, suprime o crescimento das plantas daninhas e reduz a temperatura do solo.

De acordo com International Centre for Research on Agroforestry - ICRAF (1989), os efeitos das árvores, a curto prazo, na fertilidade do solo estão associados com a decomposição das folhas e a formação da liteira, enquanto os de longo prazo estão relacionados com a decomposição das raízes e melhorias nas propriedades físicas do solo. Hazra (1990) encontrou que a fertilidade do solo e sua propriedade de retenção de água foram favorecidas em um sistema silvopastoril após 10 anos de plantação, quando comparado a locais sem a presença de árvores. Pathak \& Gupta (1987) reportam que a adição de matéria orgânica através da liteira de folhas em uma plantação de leucaena é de cerca de 5,6 tons.ha ${ }^{-1}$.ano ${ }^{-1}$, o que melhorou a capacidade de troca de cátions (CTC) e de retenção de água, a densidade do solo, reduziu o $\mathrm{pH}$ do solo alcalino a níveis aceitáveis e melhorou o rendimento das culturas sucessivas.

Goldthorpe (1996) estudando seringais adultos verificou que o acúmulo de fitomassa deste sistema é equivalente ao dos sistemas naturais de florestas tropicais úmidas, bem como os níveis de dióxido de carbono, oxigênio e água reciclados. Bernardes et al. (2000), em estudo no sul da Bahia, encontraram teores de matéria orgânica no solo próximos aos encontrados na mata original após a implantação de seringueira em SAF. Para estes, a recuperação do solo deveu-se principalmente à proteção contra a erosão, à menor oxidação da matéria orgânica resultante de uma menor temperatura do solo e à produção de fitomassa pela cobertura vegetal.

O crescimento dos brotos é menos influenciado por interações competitivas quando comparados ao crescimento das raízes. Por exemplo, as gramíneas inibem o crescimento das raízes das árvores, por aumentarem a concentração de $\mathrm{CO}_{2}$ e diminuírem a de $\mathrm{O}_{2}$ no solo (Howard, 1925). As principais razões de competição e interação de raízes são: o efeito alelopático do sistema radicular, as folhas e a competição por nutrientes e por água (Jha, 1995).

Existem evidências suficientes, de que os SAFs mantém as propriedades físicas do solo, características não menos importantes que a quantidade de nutrientes 
disponíveis às plantas. $\mathrm{O}$ bom crescimento das raízes e seu favorecimento dependem, entre muitos outros fatores, da resistência do solo ao crescimento das raízes, suprimento de água, aeração, etc. (Jha, 1995). Mann \& Muthana (1984) observaram que a temperatura média máxima do solo abaixo das árvores foi menor de $10-16{ }^{\circ} \mathrm{C}$ entre 10 $15 \mathrm{~cm}$ de profundidade e de $4-5^{\circ} \mathrm{C}$ a $30 \mathrm{~cm}$ de profundidade, quando comparado a um local aberto.

Ramkrishna (1984) observou que em uma plantação de Acacia tortilis de 13 e 7 anos de idade e em outra de Holoptelia integrifolia de 8 anos, a interceptação da preceituação foi de $23-33 \%$ e $14-19 \%$ para as acácias e de 3-8\% para a Holoptelia sob chuva moderada a pesada (20 a $35 \mathrm{~mm}$ ). Tal fato foi atribuído ao formato da copa e à densidade da cobertura.

Há ainda muita controvérsia acerca dos efeitos presumivelmente positivos do sombreamento sobre o crescimento/produção de café. Existem exemplos que demonstram tanto incrementos como decréscimos da produção de café, em função da arborização $\left(\right.$ Ortolani $\left.^{5}\right)$. Em condições ambientais adequadas e com a utilização intensiva de insumos, plantios a pleno sol usualmente sobrepõem-se, em termos de produção, aos arborizados (Beer et al., 1998). O mesmo autor afirma que limitações nutricionais e de umidade aumentam o grau de necessidade de sombreamento para o cafeeiro. Aparentemente, o sombreamento pode favorecer a cultura do cafeeiro em regiões marginais, onde as condições de solo e clima não são plenamente favoráveis à cultura (Lunz et al., 2004).

A densidade e a arquitetura da copa das espécies mais altas determinam a fração de energia solar que pode ser capturada pelas plantas dos estratos inferiores (Monteith, 1965). Dessa maneira, os efeitos do sombreamento sobre a fisiologia do cafeeiro são importantes na determinação dos níveis ótimos de radiação e temperatura, uma vez que, estes são fundamentais aos processos fotossintéticos (Morais et al., 2003). Nesse sentido, o estudo das respostas fisiológicas dos cafeeiros às diferentes intensidades de sombreamento e interações árvore-cultura podem auxiliar na determinação da composição de espécies e manejo dos SAFs (Cannell, 1976; Baggio et al., 1997).

\footnotetext{
${ }^{5}$ Ortolani, A. Comunicação pessoal, 2002.
} 


\section{4 Modelagem e simulação}

Segundo Penning de Vries (1982) e De Wit (1993), um sistema é uma parte limitada da realidade com elementos inter-relacionados e um limite definido, com uma pequena influência em seu meio ambiente. Para Caswell et al. (1972), um sistema é uma coleção de objetos inter-relacionados. Um objeto é descrito por uma série de comportamentos que por sua vez constitui-se numa série de ações no tempo. Dentro do sistema, essas relações são conhecidas como estrutura, e tanto os modelos como os sistemas possuem uma estrutura característica.

Um sistema, de qualquer natureza, pode ser estudado pela distinção e caracterização de seus componentes principais, ou através de equações que representem as mudanças internas, externas e suas inter-relações com o meio, de tal forma que se caracterizem num modelo do sistema original (Leffelaar, 1993).

Uma definição razoável de simulação é a "construção de um modelo e estudo do seu comportamento". A simulação é utilizada para estimular e aumentar a compreensão da realidade através de analogias e extrapolações quando o sistema estudado é muito complexo e o caminho analítico-matemático torna-se muito difícil (Bos \& Rabbinge, 1976).

A realização de planejamentos e análises ambientais racionais e adequadas foram em muito facilitadas com o emprego dos computadores. Para Crestana (1994), é possível observar, modelar, avaliar e simular as variáveis edafoclimáticas, a fim de proporcionar maior segurança quanto aos resultados esperados com economia de tempo e recursos. Modelagem e simulações não geram dados, porém podem testar e gerar hipóteses, orientar a experimentação no campo e prever o comportamento de determinado sistema em condições desconhecidas (Pereira, 1984).

A utilização de modelos matemáticos, assim como o planejamento prévio da pesquisa, é mais importante em sistemas agroflorestais do que em sistemas de monocultivo. $\mathrm{O}$ enfoque puramente experimental em agrossilvicultura é excessivamente caro devido: (i) a longevidade das árvores, (ii) o tamanho das parcelas experimentais e (iii) ao grande número de possíveis disposições em relação ao tempo e espaço. Faz-se 
necessário uma avaliação prévia da literatura existente, bem como, o desenvolvimento e a utilização de modelos matemáticos (e seu aprimoramento) para testar previamente as hipóteses levantadas (Bernardes, 1993).

O estudo de SAF é de grande complexidade e de natureza interdisciplinar, o que dificulta o desenvolvimento de modelos que vão aos poucos sendo montados, identificando pontos que precisam ser estudados. Desta maneira, a modelagem pode ser vista como peça-chave para determinação e coordenação de estudos experimentais baseados em processos, o que levará ao entendimento do funcionamento dos SAFs, colocando bases sólidas para a manipulação de seus componentes (Sá, 1994). Também Muetzelfeldt \& Sinclair (1993) são taxativos ao afirmarem que a modelagem faz parte dos aspectos estratégicos da pesquisa em SAF, pois é uma técnica que pode integrar conhecimentos de diferentes disciplinas em uma estrutura de trabalho comum e definir metas claras para pesquisa e opções de manejo agroflorestal. Neste contexto, outras importantes referências de modelagem matemática em SAF são Ong et al. (1996), Young (1997a) e Sinclair e Lawson (1997) que sintetizam, apresentam e analisam diversos modelos para aplicação em SAFs, incluindo crescimento, produção, disposição, diversos tipos de interações entre culturas, árvores e ambiente abaixo e acima do solo.

\section{5 Justificativa}

Segundo Sá (1994), apesar do grande alarde sobre os benefícios ecológicos e ambientais que os SAFs possam trazer, é ainda difícil quantificar as modificações micrometeorológicas e suas repercussões ecofisiológicas decorrentes da sua implantação, bem como as possíveis implicações em escala local e regional. Ainda são poucos os trabalhos que têm monitorado variáveis biofísicas nestes sistemas, notadamente nos trópicos úmidos.

Mesmo que a planta de café cultivada a pleno sol tenha um comportamento bom sob determinadas condições, não significa que as plantações devam ser estabelecidas nesta condição e não à sombra, pois não é fácil conseguir locais onde as condições ambientais e de solo sejam ótimas, para que se omita o uso da sombra. Pelo contrário, 
com o uso de uma sombra regulada, pode-se obter produções altas, reduzir a taxa de senescência da planta, diminuir o risco de ataque de doenças como a cercosporiose, que se desenvolve melhor em cultivos a pleno sol, reduzir a demanda hídrica e de nutrientes do cultivo (Evanoff, 1994) e, bem como a incidência de plantas daninhas e de bicho mineiro (Campoe et al., 2003a e b).

Provavelmente, há uma relação entre o sistema de produção adotado para o cafeeiro e a qualidade de bebida. Shoubo et al. (1991) demonstraram que na cultura do chá (Camellia sinensis) o sombreamento provocado por árvores em SAF causou o aumento da concentração de compostos nitrogenados e a redução de polifenóis. Estas modificações foram benéficas para o sabor e aroma do chá verde. O mesmo efeito pode ser esperado na cultura do cafeeiro. Este aspecto é sobremaneira importante, pois define a taxa de retorno financeiro que o produtor irá alcançar com seu produto, dada a grande variação de preço entre as diferentes qualidades de bebida (International Coffee Organization - ICO, 2004).

O entendimento de como sistemas agroflorestais utilizam os recursos disponíveis é fundamental para o estabelecimento de combinações de espécies, arranjo da plantação, densidade de plantio e manejo adequado para diferentes localidades. O estudo dos princípios da captação de recursos em SAF é útil na análise de desempenho das culturas envolvidas sob várias condições de clima e manejo (Ong et al., 1996).

Apesar da cultura do cafeeiro ser muito tradicional em nosso país, ainda existem dúvidas quanto ao comportamento do cafeeiro em diferentes situações. O entendimento dos processos ecofisiológicos envolvidos na produção de café poderá contribuir para uma maior estabilidade da produção e dispersão da cultura a locais ainda considerados marginais ou inaptos. O estudo do cafeeiro em SAF constitui-se um campo novo para o conhecimento e é objeto de grande interesse sócio - econômico. Dadas às controvérsias existentes e anteriormente citadas é importante definir o sombreamento adequado ao cafeeiro, de modo a maximizar os efeitos positivos e minimizar os negativos dessa prática. 


\section{6 Objetivos}

O objetivo desta pesquisa foi avaliar o comportamento do cafeeiro sob diferentes condições de cultivo sejam, intensidade de sombra e demais interações com a seringueira.

\section{7 Hipóteses}

As hipóteses do trabalho são:

1. A redução da disponibilidade de luz pelas árvores afeta o crescimento dos cafeeiros positivamente pela redução da transpiração e negativamente pela redução da fotossíntese líquida expressa como acúmulo de matéria seca da parte aérea;

2. Existe competição por luz entre o cafeeiro e a árvore sombreadora, sendo esta proporcional à distância entre as culturas e ao tamanho da árvore sombreadora;

3. O modelo matemático utilizado descreve adequadamente a disponibilidade de luz à cultura intercalar e pode ser uma importante ferramenta no desenho de SAFs.

\section{8 Material e Métodos}

\section{8. 1 Local da realização do experimento}

O experimento foi realizado em cafezal, plantado no espaçamento de 3,40 x 0,9 m, pertencente ao Departamento de Produção Vegetal da Escola Superior de Agricultura "Luiz de Queiroz" da Universidade de São Paulo (ESALQ/USP) em Piracicaba-SP (2242’30” S, 47³8’00” W - altitude $554 \mathrm{~m})$. De acordo com Sentelhas et al. (1998), o clima é sub-tropical úmido, com verão chuvoso e seca no inverno, sendo identificado como Cwa segundo a classificação de Köppen. A temperatura média anual é de $21,4{ }^{\circ} \mathrm{C}$, com temperaturas médias mensais de $24,8{ }^{\circ} \mathrm{C}$ no verão e $17,1^{\circ} \mathrm{C}$ no inverno. A precipitação média anual é de $1.278 \mathrm{~mm}$, distribuídos em $1.000 \mathrm{~mm}$ de outubro a março e $278 \mathrm{~mm}$ entre abril e setembro. 
Esse campo foi escolhido pela existência de seringueiras com 12 anos de idade com cafeeiros plantados no interior do seringal e em sua interface (Figura 01). A área total ocupada pelas culturas do cafeeiro e da seringueira foi de 4,5 ha.

\section{8. 2 Características do solo}

A área experimental está localizada num terreno plano a levemente ondulado com declividade de 0 a 1,5\%, cujo solo classifica-se como Nitossolo vermelho eutroférrico (Embrapa, 1999) (Terra Roxa Estruturada), eutrófico, horizonte A moderado e textura argilosa, classificação americana Kandiudalfic Eutrodox. A boa fertilidade do solo e a existência de sistema de irrigação instalado nesse local evitaram limitações ao crescimento e desenvolvimento das plantas além daquelas oriundas dos tratamentos experimentais (competição entre culturas), sendo também representativo de cafezais implantados comercialmente.

$\mathrm{Na}$ implantação do cafeeiro foi realizada análise de solo, servindo esta para as correções e adubações necessárias a cultura. As amostras de solo foram retiradas de 0 a $20 \mathrm{~cm}$ de profundidade em zig-zag, em área total compondo uma amostra única. 


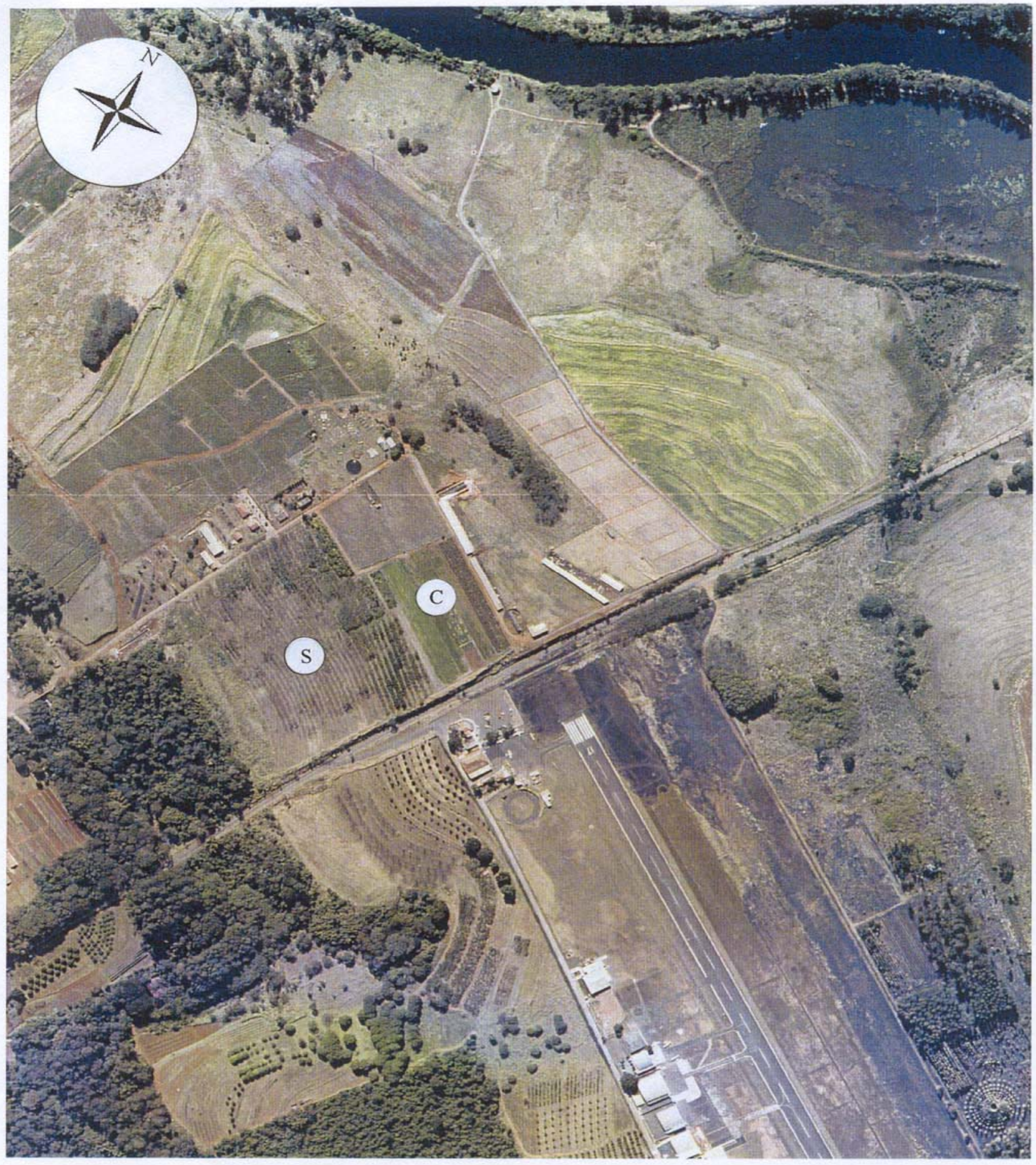

Figura 1 - Vista aérea do campo experimental pertencente ao Departamento de Produção Vegetal da Escola Superior de Agricultura "Luiz de Queiroz" da Universidade de São Paulo (ESALQ/USP) em Piracicaba-SP (22 $42^{\prime} 30^{\prime \prime}$ S, 47³8’00” W - altitude $\left.554 \mathrm{~m}\right)$. Nesta fotografia de 2002 as seringueiras (PB 235) (S) encontram-se com 11 anos de idade tendo o dossel das árvores já se fechado. A cultura do cafeeiro foi implantada na área demarcada (C) 


\section{8. 3 Delineamento experimental}

Foram avaliados os cafeeiros plantados em espaçamento de 3,4 x 0,9 m dentro e ao lado do seringal, simulando aléias de seringueiras em espaçamento $8 \times 2,5 \mathrm{~m}$ e também em monocultivo no mesmo espaçamento. $\mathrm{O}$ experimento foi conduzido com 11 tratamentos - distância das árvores - com quatro repetições cada, sendo estes:

Cada parcela experimental era constituída de uma área de $12,5 \times 32,8 \mathrm{~m}$, como está disposto no esquema das parcelas de amostragem (Figuras 2, 3 e 4). Cada parcela possuía duas linhas de seringueira, cada uma com 6 árvores, sendo avaliadas as 4 centrais de cada linha. A primeira linha interfaceando a cultura do cafeeiro representa árvores em SAF em renque (cultivo em faixas) de linha dupla. A segunda linha representa árvores de seringueira em monocultivo em espaçamento 8 x 2,5 m. As áreas entre as parcelas eram grandes o bastante para impedir a interferência mútua (Figura 2). Os cafeeiros foram avaliados nas seguintes distâncias das seringueiras, a contar da borda do plantio das árvores: (dentro) -13,7; -10,3; -5,7; -2,3 m; (ao lado) 1,5; 4,9; 8,3; 11,7; 15,$1 ; 18,5 \mathrm{~m}$ e em monocultivo. 
Bloco A

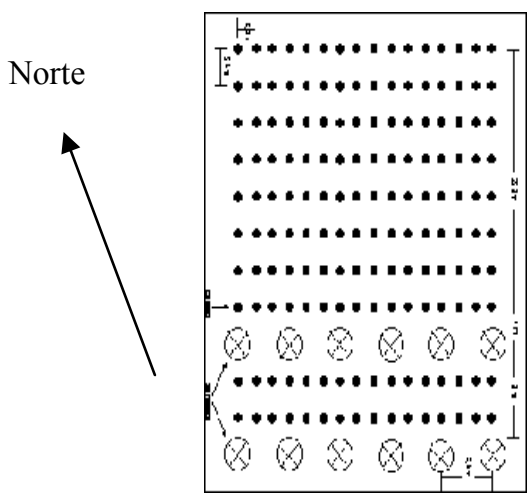

Bloco B

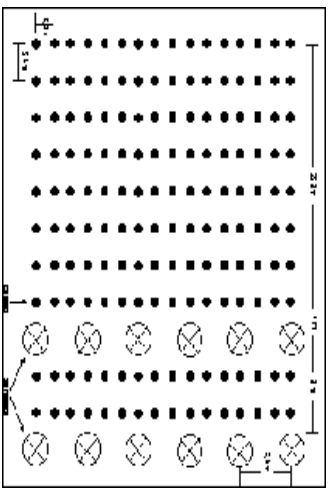

Bloco C

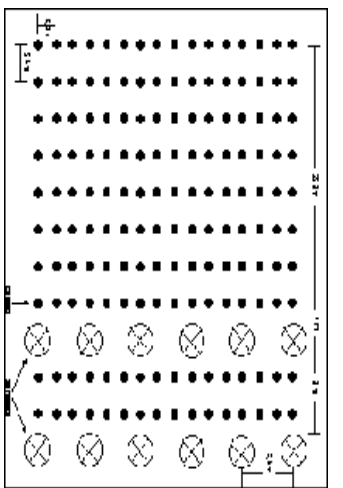

Bloco D

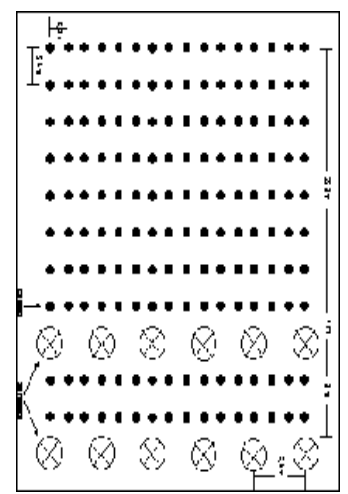

Figura 2 - Esquema geral do delineamento experimental e disposição dos tratamentos e blocos no campo

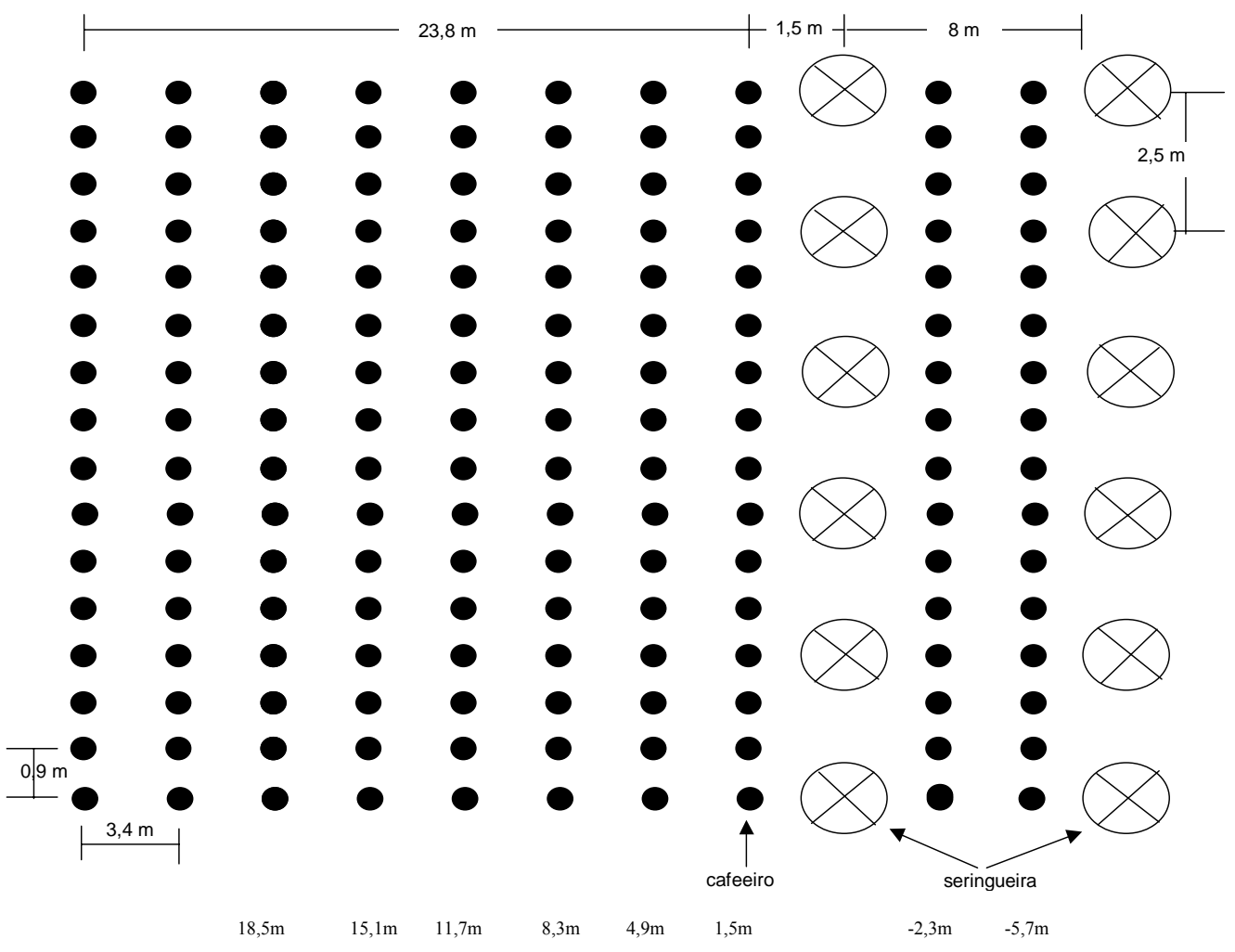

Figura 3 - Esquema do bloco experimental evidenciando a disposição das culturas na área experimental 


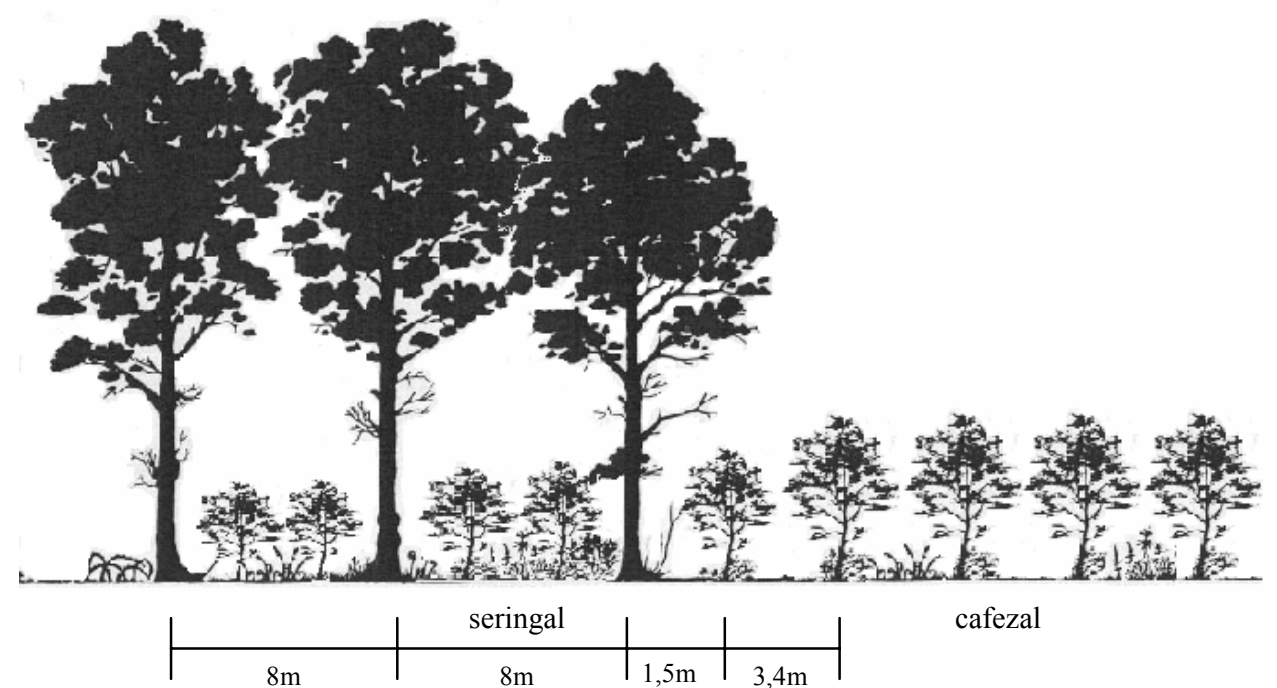

Figura 4 - Desenho esquemático de um corte transversal do campo experimental evidenciando a disposição das árvores de seringueira e dos cafeeiros

\section{8. 4 Instalação e manejo das culturas}

O seringal foi plantado em 1991 com mudas enxertadas em sacolas plásticas com 2 lançamentos foliares maduros do enxerto. Todos os blocos experimentais foram compostos por árvores do mesmo clone - PB-235. A cultura do cafeeiro, cultivar Obatã, IAC - 1669-20, foi plantada no início de janeiro/2002 com mudas de 9 meses de idade. Todas as mudas foram produzidas no próprio departamento, oriunda de semeadura direta em sacolas plásticas e permanência em viveiro com sombrite apropriado. A condução das culturas (adubação, irrigação e proteção) pretendeu evitar limitações do crescimento potencial.

Toda a área experimental foi irrigada por gotejamento. A evapotranspiração da cultura do cafeeiro foi estimada pelo uso de um tanque Classe A pertencente à estação meteorológica do Departamento de Ciências Exatas da ESALQ-USP localizado ao lado do experimento. A lâmina de irrigação foi calculada de acordo com o método proposto por Villa Nova e Sentelhas (1999), onde ficou evidenciada a correlação entre a 
evapotranspiração da cultura (ETC), o índice de área foliar (IAF) e a evapotranspiração do tanque Classe A (ECA) medidos.

O manejo das culturas seguiu as recomendações técnicas para cada espécie e contou-se com as orientações dos Profs. Drs. José Dias Costa e José Laércio Favarin do Dept. Produção Vegetal da Escola Superior de Agricultura "Luiz de Queiroz" ESALQ/USP.

\section{8. 5 Determinação experimental dos parâmetros analisados}

Para testar as hipóteses levantadas, avaliaram-se os cafeeiros em relação à distância das árvores e o grau de sombreamento e competição por elas causadas.

\section{8. 5. 1 Cafeeiro e seringueira}

Foram sorteadas 12 plantas por linha amostrada, totalizando 528 cafeeiros. Os cafeeiros amostrados foram identificados com etiquetas de cartolina, impermeabilizadas por banho em parafina e amarradas com barbante. No sorteio dos cafeeiros em cada posição, tomou-se o cuidado de evitar plantas localizadas ao lado de falhas, evitando-se assim o efeito de dossel aberto.

A área foliar (AF) de todos os cafeeiros sorteados foi obtida contando-se o número de folhas e medindo-se a largura e comprimento da folha média. Desse modo, a AF dos cafeeiros foi estimada pela substituição dos valores determinados na equação (1):

$$
A F=\left(N \times F_{m}\right) \times \mathrm{K}
$$

onde $N$ é o numero de folhas; $F_{m}$ é a área da folha média corrigida pelo fator $K$ $(K=0,6862)$. O valor de $K$ foi determinado experimentalmente medindo-se o comprimento e a largura de 100 folhas médias e mensurando suas áreas com o auxílio do integrador de área foliar - Li-3100 (Li-COR Inc) - e fazendo sua correlação linear. O índice de área foliar (IAF) de cada cafeeiro foi obtido dividindo-se sua AF por sua área de projeção de copa, esta considerada com um formato circular. 
A Área Foliar Específica (AFE) $-\mathrm{m}^{2}$ folha. $\mathrm{kg}^{-1}$ - foi avaliada pelo método de pesagem de área de folhas conhecidas e da massa seca total das folhas. Dez folhas por planta, em apenas um dos blocos, foram coletadas nas mesmas posições de avaliação e devidamente empacotadas e identificadas. A área das folhas foi medida utilizando-se um integrador de área foliar de marca Li-COR, modelo 3100, sendo posteriormente secas em estufa de ventilação forçada a temperatura de $65^{\circ} \mathrm{C}$ até atingirem peso constante em balança eletrônica marca BEL-Brasil - Modelo Mark 3.500. A Área foliar específica do cafeeiro foi então calculada pela divisão da área foliar pela massa de folhas.

As características de copa do cafeeiro foram mensuradas de acordo com metodologia proposta por Leong (1980), sendo estas: 1 comprimento da copa - é a diferença entre as medidas de altura da árvore e altura do tronco; $2 \bullet$ porcentagem de copa - é a porcentagem do comprimento da copa sobre a altura da árvore; $3 \bullet$ grau de abertura da copa - é a porcentagem do diâmetro médio da copa sobre a altura da árvore; 4 razão de preenchimento da copa - é o quociente entre o diâmetro médio e o comprimento da copa, e indica o grau de arredondamento da copa; $5 \bullet$ razão de projeção da copa - é a porcentagem do diâmetro médio da copa sobre o diâmetro do tronco; $6 \bullet$ volume da copa - calculado também se considerando um formato cônico e; $7 \bullet$ densidade foliar - é o quociente entre a área foliar total pelo volume da copa.

A altura do arbusto e a altura do tronco foram medidas diretamente com a trena, ou a depender das condições, utilizando-se o altímetro de Haga, que mede altura por hipsometria. A altura do arbusto está definida como a distância entre o ponto mais alto da copa e o solo. A altura do tronco refere-se à distância entre o ponto de inserção do ramo mais baixo e o solo.

O diâmetro da copa foi medido diretamente com a trena, e a depender da situação, com o auxílio de um instrumento desenvolvido por Shepperd (1973) e utilizado em seringueira por Bernardes (1989) e Righi (2000). O instrumento contém um espelho em um ângulo de $45^{\circ}$ com o plano horizontal que permite visualizar a borda da copa, estando o operador posicionado sob esta. A distância entre o instrumento e o tronco fornece o raio da copa, que adicionado ao raio do lado oposto fornece o diâmetro. As 
copas de todas as árvores e arbustos selecionados de cada tratamento foram medidas. Esse instrumento foi utilizado somente nas árvores sombreadoras.

Neste experimento, a transpiração dos cafeeiros foi estimada pelo método de balanço de calor através de sensores construídos pela Dynamax Inc., instalados no tronco dos cafeeiros e ligados à um sistema de aquisição de dados, modelo CR10X Campbell Scientific Inc. Para os cafeeiros, utilizou-se os sensores modelos SGA-10 e SGB-25. Tal método baseia-se na aplicação de calor em um segmento de tronco, medindo-se suas perdas por condução axial (para cima e para baixo) e radial (assume-se uma constante para o fluxo de energia que migra ao interior da planta em função de sua constituição) e a variação da energia térmica armazenada. $O$ fluxo de seiva é portanto determinado pelo balanceamento dessas perdas e a potência aplicada (Marin, 2003), sendo esta uma técnica precisa e de boa resposta dinâmica (Angelocci, 2001). Tal método é talvez o mais utilizado, possivelmente por não necessitar de calibração (Angellocci e Valancogne, 1993). No Brasil, tal método foi utilizado com sucesso por Trejo-Chadia (1997), Marin et al. (2002) e Coelho Filho (2002) em tomateiro, limoeiro e plantas de milho. Não há registros na literatura de sua utilização em seringueiras.

Estes instrumentos foram instalados nos cafeeiros situados no interior do seringal, a -5,7 m, ao lado, a 1,5; 4,9; 11,7 m e em monocultivo perfazendo 5 posições avaliadas. Dada a limitação de instrumentos somente uma planta por posição foi avaliada, considerando-se assim uma repetição das medidas no tempo.

Todas as medições detalhadas foram realizadas e avaliadas em função da distância entre o cafeeiro e as árvores sombreadoras.

As árvores sombreadoras dos SAFs foram avaliadas quanto às mesmas características mencionadas para o cafeeiro. Todas as árvores foram avaliadas e numeradas com tinta látex para a organização e norteamento em campo (Figura 5).

Os sensores de fluxo de seiva modelo SGA-150 - WS - Dynamax Inc. foram construídos sob encomenda do Departamento de Produção Vegetal - ESALQ/USP, de modo que ocorresse um ajuste destes com os troncos das árvores, o mais próximo do ideal. Sensores do método da sonda dissipadora de calor (Método Granier, citado por Angelocci, 2002) foram construídos para a estimativa da transpiração das árvores de 
seringueira e do cafeeiro. Estes instrumentos constituem-se de um par de agulhas conectadas por um termopar com junções de cobre-constantan, sendo que em uma delas existe uma pequena resistência aquecedora ligada a uma fonte de energia. Essas foram inseridas no tronco da seringueira em oito diferentes árvores, e conectadas ao mesmo sistema de aquisição de dados descrito anteriormente (Figuras $5 a$ e $b$ ). Por amostrar somente a variação de temperatura da parte mais exterior do tronco, o método do balanço de calor pode ser limitado a plantas de caule/tronco de pequeno diâmetro. $\mathrm{O}$ método da sonda de calor, apesar de ser intrusivo, por amostrar a variação de temperatura do interior à superfície do tronco, pode amostrar dados mais reais da transpiração de árvores. Além disso, as sondas podem ser construídas facilmente em laboratório, utilizando-se de solda, termopares e agulhas de injeção, sendo portanto de baixo custo, além de ocupar apenas um canal no data-logger, enquanto o outro método utiliza-se de quatro canais.

As Figuras $6 a ; b$ e $c$ ilustram a fase de crescimento da cultura do cafeeiro por ocasião do experimento, bem como, uma visão parcial da interface seringueira - cafeeiro e de seu interior. Nas Figuras $7 a$ e $b$, podemos visualizar o dossel formado pelas seringueiras e o tipo de cobertura do solo proporcionado ao cafeeiro. Nota-se o agrupamento de folhas em pequenos tufos espalhados nas pontas dos ramos.

\section{8. 5. 2 Medidas microclimáticas}

As condições de luz disponível aos cafeeiros foram medidas continuamente por tubos solarímetros (TS-UM-3, Eijkelkamp). Essas medições permitem a estimativa da transmissão e absorção de luz pelas árvores e a disponibilidade de luz ao cafeeiro em relação à distância das seringueiras. A disposição dos tubos solarímetros na área experimental deu-se em função da distância do tronco da árvore sombreadora (Figuras 2 e 4). Nas Figuras $8 a$ e $b$ visualiza-se a disposição dos tubos solarímetros, partindo do seringal, instalados nas mesmas posições em que se encontram os cafeeiros em relação à distância das árvores, bem como as estações meteorológicas 


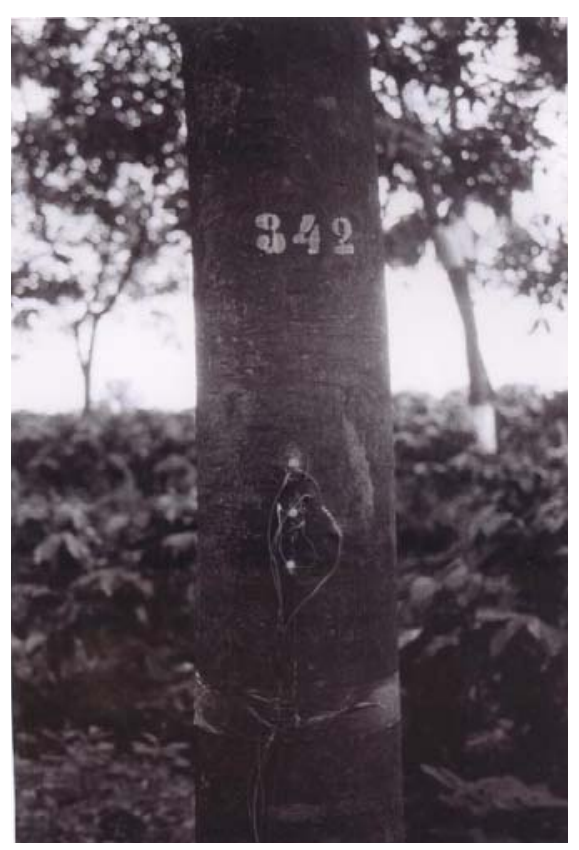

Figura $5 G$ - Visualização do sensor de fluxo de seiva do método da sonda de Calor Método de Granier de construção própria em seringueira do experimento.

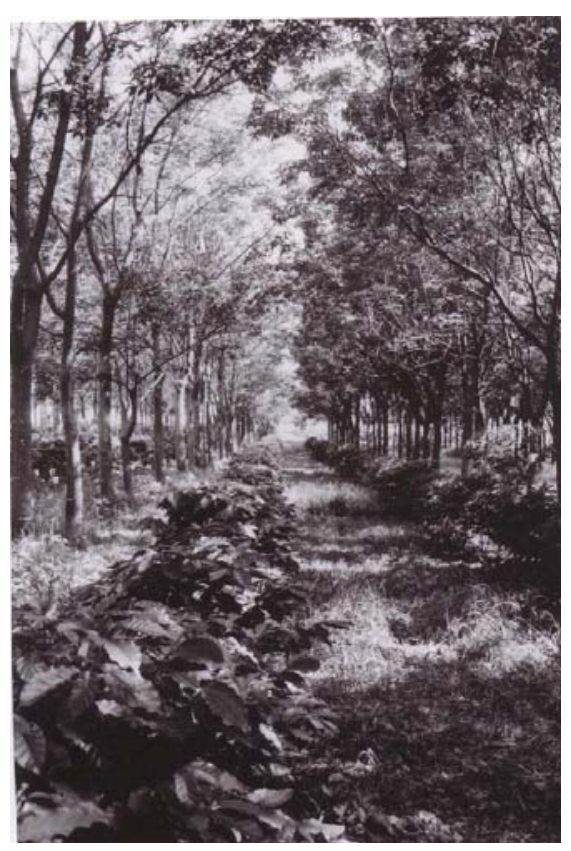

Figura $6 a$ - Vista parcial do interior do seringal demonstrando a fase de crescimento da cultura do cafeeiro por ocasião do experimento.

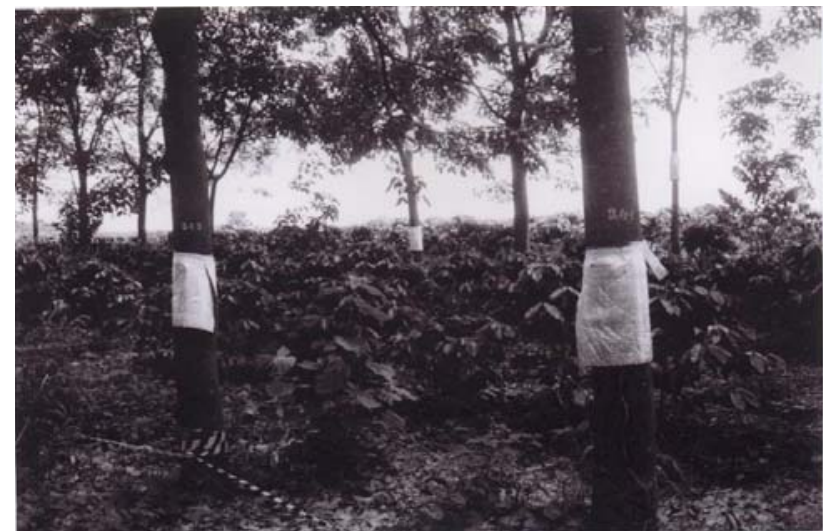

Figura $5 b$ - Vista parcial do interior do seringal - árvores da primeira e segunda linha - com os sensores de fluxos de seiva do Método de Granier.

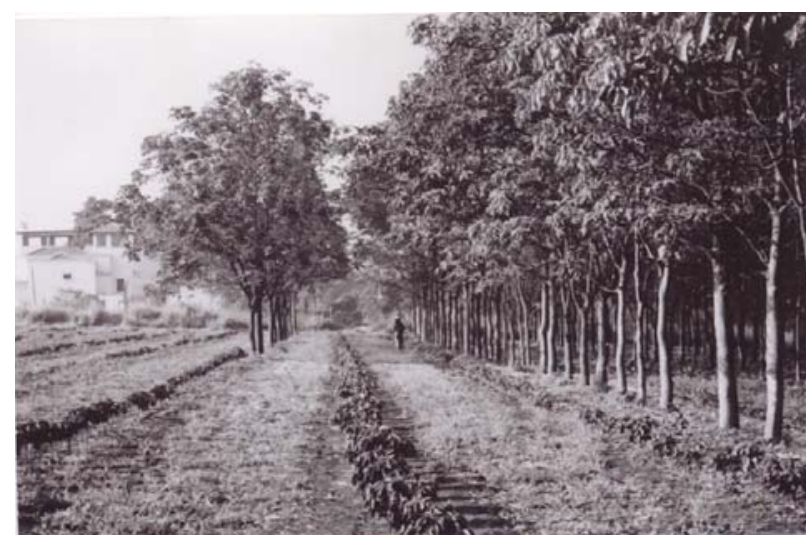

$b$

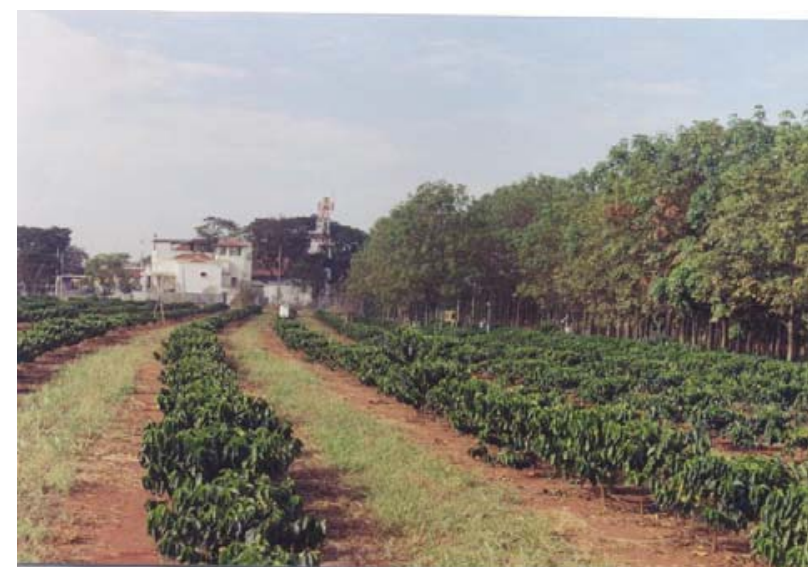

Figura $6 b$ e $c$ - Vistas parciais da interface seringueira - cafeeiro onde pode-se observar a disposição das culturas no campo experimental. 


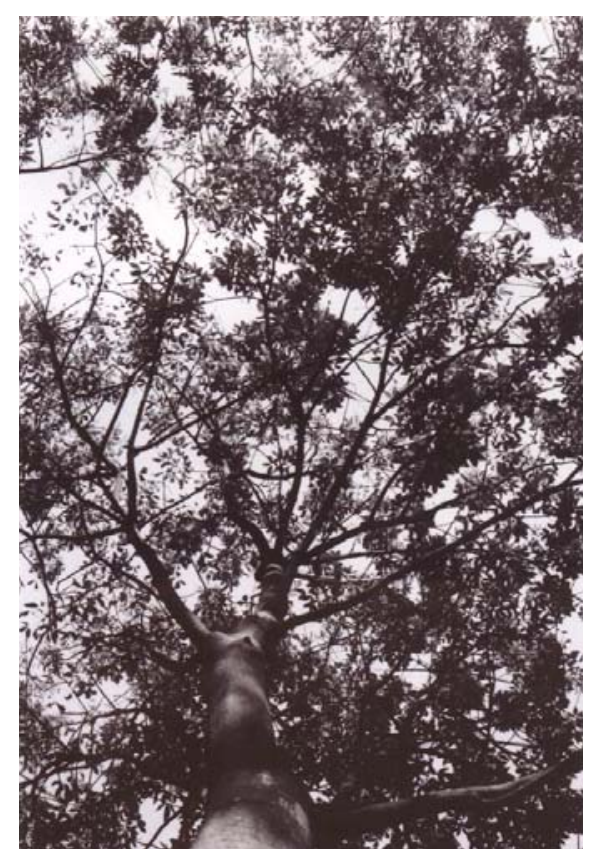

$a$

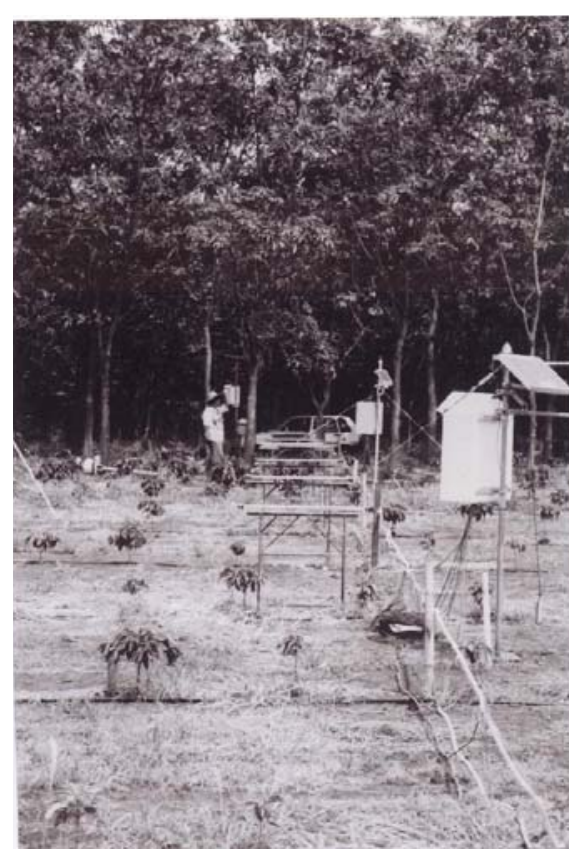

$a$

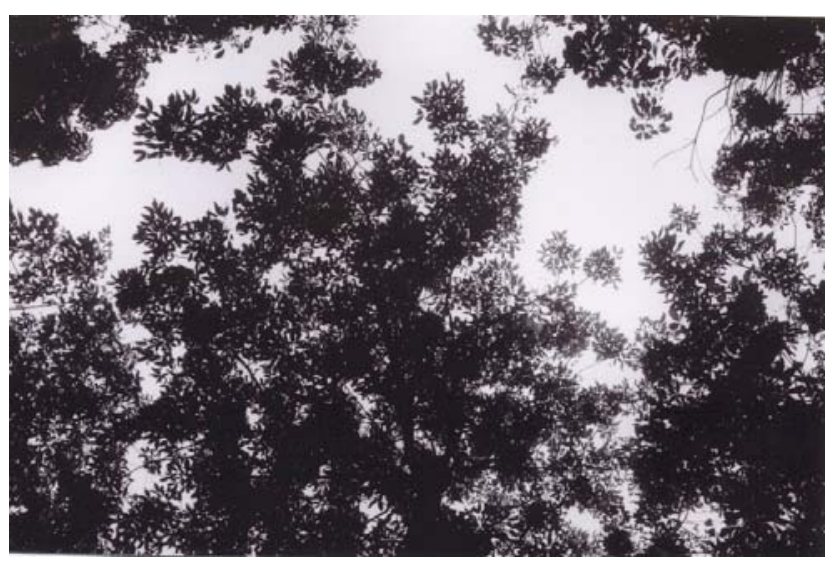

Figura $7 \boldsymbol{C}$ e $b-$ Visualização do dossel formado pelas seringueiras e do tipo de cobertura do solo proporcionado aos cafeeiros. Pode-se observar o agrupamento de folhas em pequenos tufos espalhados nas pontas dos ramos característicos de seu desenvolvimento.

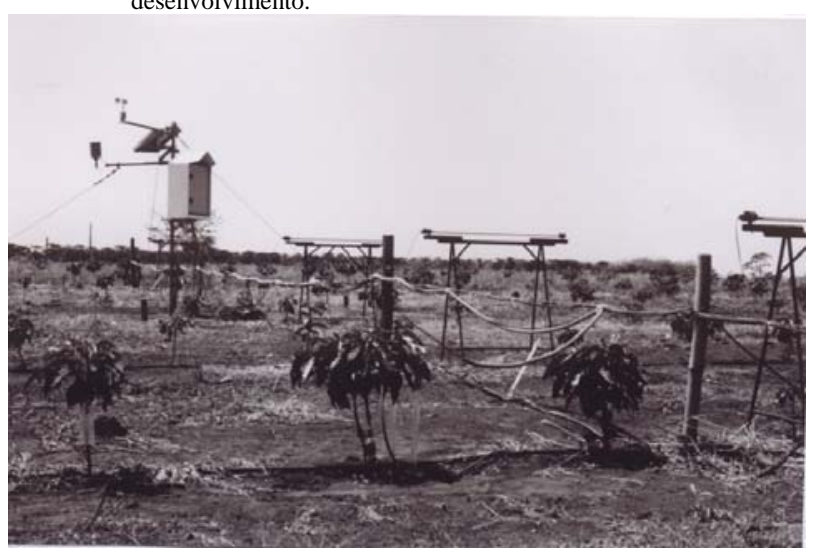

Figura $8 \boldsymbol{Q}$ e $b$ - Vista da disposição dos tubos solarímetros (TS-UM-3, Eijkelkamp) e da estação micrometeorológica (Delta-T Devices Inc.) no campo experimental - Piracicaba-SP.

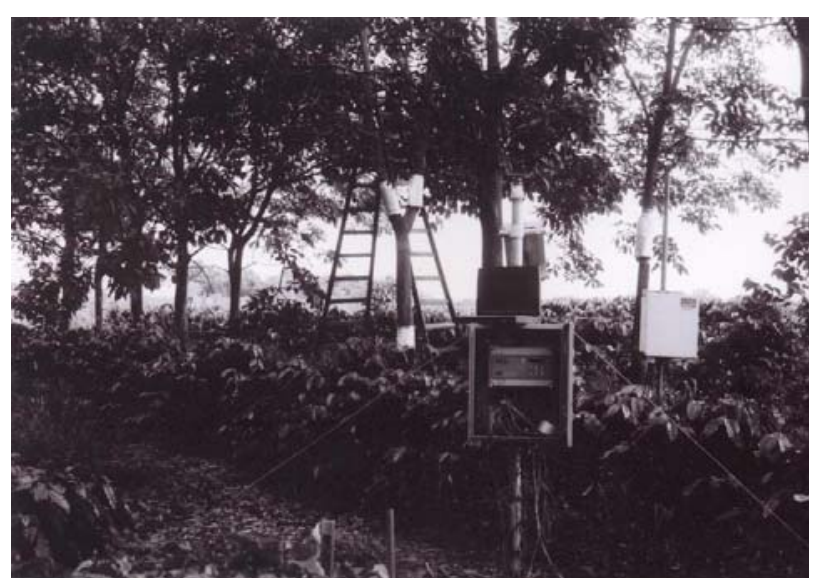

Figura 9 - Vista parcial do interior do seringal onde podemos observar as árvores com os sensores de fluxos de seiva do Método de Granier e o data-logger (Delta-T Devices Inc.) utilizado na coleta de seus dados. Observar árvore ao fundo com sensores tanto em seu tronco como nos dois ramos em que se subdivide para verificação de seu funcionamento. 
Uma estação micro-meteorológica automática foi instalada na área do experimento, medindo continuamente a radiação global (piranômetro, CM3, Eijkelkamp), além de 10 tubos solarímetros (TS-UM-3, Eijkelkamp) (Figura 8). A coleta dos dados climáticos visou a utilização dos resultados experimentais em modelo matemático para extrapolação dos resultados do estudo. Também dois data-loggers modelo CR10X (Campbell Scientific Ltd.) foram instalados para a coleta de dados de fluxo de seiva dos 2 diferentes métodos avaliados (Figura 9).

\section{8. 5. 3 Modelo matemático}

Os resultados experimentais foram utilizados para a avaliação do modelo matemático original proposto por Goudriaan (1977) e adaptado por Bernardes et al. (1998b) (2), que é utilizado para calcular a irradiância (Ir) que atinge as entrelinhas da cultura em renque. O referido modelo simula a disponibilidade de radiação luminosa para a cultura intercalar em função da distância da linha de árvores sombreadoras (d); da irradiância diária $\left(\mathbf{I}_{0} \mathrm{MJ} . \mathrm{m}^{-2}\right)$ numa superfície horizontal acima da copa das árvores; do raio da copa ( $(\mathbf{w}$ m); da declividade do terreno em radianos e da altura (Hr m) relativa das árvores.

\section{9 Forma de Análise dos Resultados}

A análise estatística do experimento foi realizada com o programa SAS (Statistic Analysis System). A comparação entre cafeeiros foi realizada através de análise de delineamento de parcelas subdividas em faixas (strip-plot), considerando cada distância em relação às árvores sombreadoras avaliada como um tratamento. Além disso foi realizada análise de regressão para os dados das diversas variáveis, considerando como variável independente a distância das árvores de seringueira. Estas são apresentadas no anexo quando significativas. A depender da necessidade cada cafeeiro foi considerado como uma amostra (capítulo 8 - matéria seca) com repetição no tempo (capítulo 9).

Os dados coletados são apresentados em forma gráfica, comparando-se sempre que possível os sistemas de cultivo - monocultivo e os diferentes SAFs. 


\section{SIMULAÇÃO E DISPONIBILIDADE DE LUZ E CRESCIMENTO DE CAFEEIROS EM SISTEMA AGROFLORESTAL COM SERINGUEIRAS}

\section{Resumo}

A radiação solar é um dos mais importantes fatores no crescimento das plantas, sendo sua disponibilidade às culturas intercalares fortemente modificada pelas árvores em um Sistema Agroflorestal (SAF). Cafeeiros (Coffea arabica L. cv. Obatã, IAC 1669-20) foram plantados no espaçamento de 3,4 x 0,9 m dentro e ao lado de um seringal em monocultivo de 12 anos de idade (Hevea brasiliensis Müell. Arg.) em Piracicaba/SP $\left(22^{\circ} 42^{\prime} 30^{\prime} \mathrm{S}, 4^{\circ} 38^{\prime} 00^{\prime}\right.$ W - altitude $\left.546 \mathrm{~m}\right)$. Os cafeeiros foram avaliados nas seguintes distâncias das seringueiras a contar da borda do plantio das árvores: (dentro) -13,7; -10,3; -5,7; -2,3 m; (ao lado) 1,5;4,9; 8,3;11,7;15,1;18,5 m e comparados ao cafeeiro em monocultivo. A disponibilidade de luz aos cafeeiros foi medida utilizando-se tubos solarímetros nas mesmas posições, relacionando-a com sua fitomassa medida acima do solo. O Índice de Área Foliar (IAF) foi estimado em função da projeção da copa. Também foram realizadas outras avaliações fitométricas dos cafeeiros, como altura da planta, largura de copa, volume de copa, etc. A disponibilidade de luz aos cafeeiros foi, respectivamente às distâncias, de: 25\%; 30\%; 35\%; 40\%; 45\%; $80 \%$; $90 \%$; $95 \%$ e de $100 \%$ para as 3 posições mais distantes. Sua estimativa, utilizandose o modelo matemático: $\mathrm{Ir}=1 / 2 . \operatorname{sen}\left[\operatorname{arctg}\left(\left(\left(\mathrm{d}-\left(\mathrm{cw}^{*} \mathrm{cw} / \mathrm{d}\right)\right) / \mathrm{Hr}\right)+\operatorname{declive}\right)+1\right]^{*} \mathrm{I}_{0}$, onde: $\mathbf{I}_{0}$ - radiação acima das árvores; hr - altura das árvores em relação a altura do cafeeiro; cw - largura da copa e; d - distância das árvores, ajustou-se aos dados medidos, podendo ser uma importante ferramenta no planejamento e análise de SAFs. O cafeeiro mostrou 
boa plasticidade, apresentando recursos de adaptabilidade a redução na disponibilidade de luz com aumento da área foliar específica, diminuição do IAF e da densidade foliar e modificações na geometria da planta e modo de interceptação e uso da radiação com menor arredondamento de copa, maior altura de tronco e menor volume de copa. A cultura não apresentou uma boa correlação linear entre a fração de radiação disponível e a fração da matéria seca devido provavelmente a sua copa já se saturar com cerca de $45 \%$ da irradiância disponível. O modelo de Gompertz apresentou um melhor ajuste aos dados obtidos. Não se observou queda no acúmulo de matéria seca com reduções de 100 a $45 \%$ da irradiância disponível. Maior redução em sua disponibilidade ocasionou acentuada diminuição do acúmulo de matéria seca diretamente proporcional, bem como modificações em suas características morfológicas dada a adaptação a estas condições. Devido à sua capacidade de adaptação a grandes reduções na disponibilidade de luz, o cultivo do cafeeiro em SAFs apresenta boa perspectiva.

Palavras-chave: luz; atenuação; seringueira; modelo; matéria seca

MEASUREMENT AND SIMULATION OF LIGHT AVAILABILITY RELATED TO GROWTH OF COFFEE PLANTS IN AGROFORESTRY SYSTEM WITH RUBBER TREES

\section{Summary}

Light is an important factor for plant growth, but its availability to understore crops is strongly modified by trees in Agroforestry System (AFS). Coffee (Coffea arabica L. cv. Obatã, IAC - 1669-20) was planted 3.4x0.9m inside and aside of 12 years old trees monocrops of rubber (Hevea brasiliensis Müell. Arg.), at Piracicaba, São Paulo

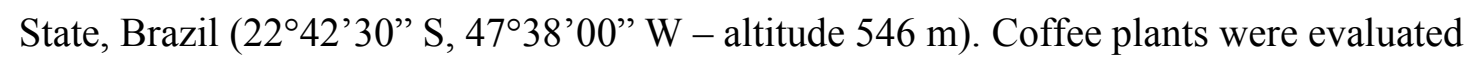
at the following distances, counting from the border of the trees crops: (inside) -13.7; $10.3 ;-5.7 ;-2.3 \mathrm{~m}$; (aside) $1.5 ; 4.9 ; 8.3 ; 11.7 ; 15.1 ; 18.5 \mathrm{~m}$ and compared to the coffee monocrop. Light availability to coffee was measured with solarimeter tubes at the same positions relating it to its measured above-ground phytomass. Leaf area index (LAI) was 
estimated in respect to canopy projection. Other phytometric measurements were also performed as plant height, canopy width, canopy volume, etc. The relative light availability was, respectively to those distances, $25 \% ; 30 \% ; 35 \% ; 40 \% ; 45 \% ; 80 \%$; $90 \% ; 95 \%$ and about $100 \%$ to the 3 farthest positions. Its estimative by the mathematical model: $\mathrm{I}_{\mathrm{r}}=\left(\mathrm{I}_{0} / 2\right)\left\{\operatorname{sen}\left\{\operatorname{arctg}\left[\left(\mathrm{d}-\left(\mathrm{cw}^{2} / \mathrm{d}\right)\right) / \mathrm{hr}\right]+\mathrm{D}\right\}+1\right\}$, were: $\mathbf{I}_{\mathbf{0}}$ - radiation above trees; $\mathbf{h r}$ tree relative height in respect to coffee height; cw - canopy width; $\mathbf{D}$ - terrain slope and; $\mathbf{d}$ - distance from the tree, fitted the measured data, which can be an important toll on AFS design and analysis. Coffee plants presented good plasticity, showing different ways of adaptability to light reduction by increasing its specific leaf area, reducing LAI and leaf density and modification on plant geometry and the way of interception and use of solar radiation with less canopy rounding off, bigger trunk height and smaller canopy volume. The culture did not presented a good linear correlation between available radiation fraction and dry matter probably due to its canopy reaches saturation with about $45 \%$ of the available radiance. The Gompertz model presented a good adjustment to the experimental data. It was not observed decrease on dry matter accumulation with reduction from 100 to $45 \%$ of the available irradiance. Further reduction on its availability leads to sharp decrease on its dry matter accumulation directly proportional as well changes on morphological characteristics due to adaptations to environmental conditions. Due to the huge adaptation capacity of the coffee plants to big reductions on light availability its cultivations on AFS presents good perspective.

Key words: light; attenuation; rubber tree; model; dry matter

\section{1 Introdução}

O café arábica (Coffea arabica L.) é originário das áreas elevadas do sul da Etiópia, localizadas próximo à linha equatorial, com latitude variando de 6 a $9^{\circ} \mathrm{N}$, longitude de 34 a $40^{\circ} \mathrm{E}$ e altitude entre 1400 e $1800 \mathrm{~m}$. Esta região possui uma estação seca de 3 a 4 meses e precipitação pluviométrica anual variando entre 1200 e $2000 \mathrm{~mm}$, distribuída ao longo do restante do ano e temperaturas variando entre 18 e $22^{\circ} \mathrm{C}$. Nesta 
zona, o cafeeiro cresce permanentemente sob sombreamento em habitat de floresta tropical (Krug, 1959; Kumar, 1979).

O cafeeiro é cultivado em ampla faixa do globo terrestre (Evanoff, 1994), sendo que na América Latina as plantações comerciais de café encontram-se distribuídas desde Cuba (latitude de $22^{\circ} \mathrm{N}$ ) até o Estado do Paraná, no Brasil (latitude de $26^{\circ} \mathrm{S}$ ). No Brasil, o cafeeiro é cultivado economicamente a pleno sol. Já em países como a Colômbia podese encontrar cultivos de café sombreado com maior freqüência. $\mathrm{O}$ cultivo do cafeeiro a pleno sol apresenta problemas como a super produção que provoca um conseqüente esgotamento das plantas nos primeiros anos. Tal situação só é posteriormente amenizada com o auto-sombreamento de suas copas (Voltan et al., 1992).

A intensidade de radiação solar incidente sobre a cultura influencia a estrutura do aparelho fotossintético. A estrutura da folha pode ser modificada pela intensidade de luz à qual esta fica exposta durante seu crescimento. Maior disponibilidade de luz proporciona aumentos na espessura da folha, na massa foliar específica, no desenvolvimento da epiderme, no desenvolvimento do parênquima e no número total de células das folhas (Esau, 1977). Fahl (1989) verificou uma maior espessura e maior densidade de células em folhas de cafeeiro desenvolvidas a pleno sol. Este mecanismo de adaptação também ocorre em outras plantas, tendo sido observado em plantas de feijoeiro uma diminuição da área foliar específica (AFE) com o aumento da irradiação (Righi, 2000).

Voltan et al., (1992) em estudos da epiderme do cafeeiro submetido a diferentes disponibilidades de luz observaram que o número de estômatos decresceu linearmente com a diminuição da irradiância, embora as dimensões dos estômatos não tenham sido afetadas significativamente. Alvim (1960), analisando a variação da taxa fotossintética e condutância estomática em Coffea arabica a pleno sol e à sombra, observou que a condutância estomática, bem como a fotossíntese líquida, foram superiores no cafeeiro sombreado. No Quênia, demonstrou-se que a fotossíntese do cafeeiro é maior em condições de baixa luminosidade. A assimilação total diária foi maior à sombra do que ao sol. A taxa fotossintética do cafeeiro varia entre $0,7 \mathrm{mg} \mathrm{CO} \cdot \mathrm{dm}^{-2} \cdot \mathrm{h}^{-1}$ em condições de campo, e $16,0 \mathrm{mg} \mathrm{CO} 2 \cdot \mathrm{dm}^{-2} \cdot \mathrm{h}^{-1}$ em condições controladas. O Coffea canephora possui 
taxas de fixação de $\mathrm{CO}_{2}$ geralmente inferiores às do Coffea arabica, havendo alguma variação genética entre os cultivares. Isto poderá indicar qual variedade se adapta melhor às condições ambientais de Sistemas Agroflorestais (SAF) (Kumar \& Tieszen, 1980a).

A presença de árvores em um sistema de produção altera o balanço de radiação, a temperatura do ar e o comportamento do vento na área sob influência destas (Monteith et al., 1991; Brenner, 1996). O efeito múltiplo destas mudanças no microclima modifica o balanço de energia disponível para o meio, acarretando mudanças no uso da água, na produtividade e no ciclo das plantas sob esta condição.

A estrutura de copa refere-se ao arranjo espacial dos órgãos de uma planta acima da superfície do solo (Campbell \& Norman, 1989). As copas das plantas desempenham um papel importante no crescimento e na produtividade. A arquitetura da copa das plantas é de grande importância, pois define o tipo de distribuição de seus galhos e folhas, e influencia o modo de interceptação e aproveitamento da radiação disponível, cuja eficiência é dada pela taxa fotossintética por unidade de área foliar (Bernardes, 1987). O índice de área foliar (IAF) e a duração da área foliar são os fatores mais importantes na determinação da produção de matéria seca e conseqüentemente do crescimento (Bernardes et al., 1996). Uma detalhada abordagem sobre as características da copa das plantas e sua relação com o ambiente pode ser encontrada em Russell et al., (1989).

A quantificação dos fatores ambientais e das respostas das plantas pode ser agregada em modelos matemáticos para aperfeiçoar sua utilidade científica e prática. A utilização de modelos matemáticos, assim como o planejamento prévio da pesquisa, é mais importante em sistemas agroflorestais do que em sistemas de monocultivo. $O$ enfoque puramente experimental em agrossilvicultura é excessivamente caro devido a: (i) longevidade das árvores; (ii) tamanho das parcelas experimentais e; (iii) grande número de possíveis disposições em relação ao tempo e espaço. Assim, faz-se necessário uma avaliação prévia da literatura existente bem como o desenvolvimento e a utilização de modelos matemáticos (e seu aprimoramento) para testar previamente as hipóteses levantadas (Bernardes, 1993). Enquanto o desenvolvimento de um modelo da cultura como um todo é uma meta de longo prazo, provisoriamente os módulos individuais de 
processos podem exercer um papel importante não apenas no entendimento do SAF, mas também na predição de seu desempenho (Bernardes, 1993). O modelo matemático proposto por Goudriaan (1977) e adaptado por Bernardes et al. (1998b) (Equação 1) estima com boa precisão os valores de radiação solar para culturas em condições de campo (Righi, 2000) e pode ser de grande valor para o estudo da quantidade de radiação disponível em um SAF.

$$
I_{r}=\frac{1}{2} * \operatorname{sen}\left(\operatorname{arctg}\left(\frac{d-c_{W} * \frac{c_{W}}{d}}{H_{r}}+D\right)+1\right) * I_{0}
$$

Em que, $\mathbf{I}_{\mathbf{r}}=$ irradiância diária $\left(\mathrm{MJ} . \mathrm{m}^{-2}\right)$ que atinge o topo da copa da cultura intercalar; $\mathbf{d}=$ distância da linha de árvores sombreadoras $(\mathrm{m}) ; \mathbf{I}_{\mathbf{0}}=$ irradiância diária $\left(\mathrm{MJ} \cdot \mathrm{m}^{-2}\right)$ numa superfície horizontal acima da copa das árvores; $\mathbf{c}_{\mathbf{w}}=$ raio da copa $(\mathrm{m}) ; \mathbf{D}=$ declividade do terreno em radianos; e $\mathbf{H}_{\mathbf{r}}=$ altura relativa das árvores $(\mathrm{m})$, obtida pela seguinte equação (2)

$$
H_{r}=H_{a}-H_{c i}
$$

em que, $\mathbf{H}_{\mathbf{a}}=$ altura das árvores $(\mathrm{m})$ e $\mathbf{H}_{\mathbf{c i}}=$ altura da cultura intercalar (m).

Um melhor entendimento das interações ecofisiológicas dentro de um SAF poderá originar novas questões científicas além de aprimorar o manejo das culturas envolvidas. O aprimoramento tecnológico, tendo como resultado maior rendimento, implicará na adoção do SAF por um número maior de produtores rurais. A expansão da diversidade de culturas com a introdução de árvores de uso múltiplo como a seringueira nas regiões de monocultivo poderá incrementar a sustentabilidade na produção.

É fundamental entender como os sistemas agroflorestais utilizam os recursos disponíveis para se estabelecer combinações de espécies, disposição das plantas, densidade de plantio e manejo adequado para diferentes localidades. O estudo dos princípios de captação de recursos em SAF é útil na análise do desempenho das culturas 
envolvidas sob várias condições de clima e manejo (ONG et al., 1996, Willey \& Reddy, 1981). Grandes vantagens das interações árvore/cultura, como reciclagem de nutrientes, maior produção de matéria orgânica, diferenças na profundidade radicular e conseqüente maior absorção de água e nutrientes, e a ação das arvores como barreira protetora contra a erosão do solo ou vento são menos evidentes e pobremente documentadas (Ong et al. 1991).

Com o aumento da quantidade de radiação disponível, diversas culturas têm seu desempenho melhorado, produzindo uma quantidade maior de matéria seca, em uma correlação linear com a radiação interceptada (Righi, 2000). Watson (1958) já havia observado que a taxa de assimilação líquida decresce quase que linearmente com o aumento do IAF, daí a proporcionalidade entre crescimento e IAF (Russell et al., 1989). Para os últimos autores, a interceptação da luz por uma copa depende de sua estrutura e da relação de matéria seca produzida por unidade de radiação interceptada. Este tipo de análise, mesmo embora freqüente em estudos de monocultivos (Pereira, 2002; Confalone, et al., 1997), ainda são poucos os trabalhos relacionando tais variáveis em SAF. Apesar de ser relativamente fácil medir as variáveis físicas, interpretar como estas mudanças influenciam as culturas de sub-bosque é muito complexo (Corlett et al., 1987).

Para Šesták (1981) a relação matéria seca/radiação pode mudar durante a vida da planta, provavelmente devido a mudanças ontogênicas na estrutura da copa, como também a alterações na atividade do dreno sobre a taxa fotossintética.

Este trabalho objetivou avaliar a adaptação e o crescimento das plantas de cafeeiro (Coffea arabica L.) em SAF em renque de seringueira (Hevea brasiliensis Müell. Arg.) sob diferentes níveis de disponibilidade de luz, e testar o modelo proposto por Goudriaan (1977) e adaptado por Bernardes et al. (1998b), para estimar a radiação disponível à cultura intercalar num SAF.

\section{2 Material e Métodos}

O experimento foi conduzido no campo experimental do Departamento de Produção Vegetal da Escola Superior de Agricultura "Luiz de Queiroz" da Universidade 
de São Paulo (ESALQ/USP) em Piracicaba-SP (2242’30”S, 47³8'00”W - altitude $554 \mathrm{~m}$ ) durante o ano de 2003. As seringueiras foram plantadas em 1991 no espaçamento de $8 \times 2,5 \mathrm{~m}$, com mudas enxertadas em sacolas plásticas com dois lançamentos foliares maduros do enxerto, sendo todos os blocos experimentais compostos por árvores do mesmo clone - PB-235. A cultura do cafeeiro foi plantada no espaçamento de $3,4 \times 0,9 \mathrm{~m}$, durante a primeira quinzena de janeiro de 2002, sob o bosque de seringueiras, interfaceando as árvores e em monocultivo. Utilizou-se o cultivar Obatã, IAC - 1669-20. As mudas tinham 9 meses de idade e eram oriundas de semeadura direta em sacolas plásticas, com permanência em viveiro com sombrite apropriado.

O terreno com declividade variando de 0 a 1,5\%, constitui-se de um Nitossolo vermelho eutroférrico (Embrapa, 1999) (Terra Roxa Estruturada), eutrófico, horizonte A moderado e textura argilosa, classificação americana Kandiudalfic Eutrodox. A fertilidade do solo e a existência de sistema de irrigação instalado na área do ensaio evitaram limitações no crescimento e no desenvolvimento das plantas além daquelas oriundas do tratamento experimental. $\mathrm{Na}$ implantação do cafeeiro foi realizada análise de solo, servindo essa para as correções necessárias.

O experimento foi conduzido em quatro blocos com 11 tratamentos cada, sendo estes as distâncias das árvores medidas a partir da primeira fileira de seringueiras interfaceando o cafezal (distância zero). As distâncias negativas referem-se ao interior do seringal e as positivas ao seu distanciamento em direção ao monocultivo de café. Assim, os tratamentos utilizados foram as distâncias $-13,7 ;-10,3 ;-5,7 ;-2,3 ; 1,5 ; 4,9$; 8,3; 11,7; 15,1 e 18,5 m (Figura 3 - item 2.8.3). Em cada bloco, foram avaliadas 12 plantas por distância, num total de 528 cafeeiros avaliados. Todos os cafeeiros foram plantados no mesmo espaçamento, livre de plantas daninhas.

A primeira linha interfaceando a cultura do cafeeiro representa árvores em SAF em renque (cultivo em faixas) de linha dupla. A segunda linha representa árvores de seringueira em monocultivo.

A cultura do cafeeiro foi irrigada por gotejamento. A evapotranspiração da cultura foi estimada pelo uso do tanque Classe A, da estação Meteorológica Principal do 
Departamento de Ciências Exatas da ESALQ-USP, localizada ao lado do experimento. A lâmina de irrigação foi calculada de acordo com o método proposto por Villa Nova e Sentelhas (1999).

Para mensuração da matéria seca dos cafeeiros, coletaram-se três plantas em cada uma das seguintes posições: $-13,7 ;-5,7 ; 1,5 ; 4,9 ; 8,3 ; 15,1 \mathrm{~m}$ e em monocultivo. Secou-se as plantas etiquetadas em estufa a $75^{\circ} \mathrm{C}$ até peso constante.

A área foliar total de cada planta de cafeeiro foi obtida pela contagem do número de folhas multiplicado pelo tamanho da folha média corrigida. Encontrou-se que a área da folha média equivale a $68 \%$ da área do retângulo calculado com base em suas medidas. O IAF do cafeeiro é então calculado com base na projeção de sua copa. As demais características dos cafeeiros tais como altura da planta; diâmetro do tronco a $5 \mathrm{~cm}$ do solo, altura do tronco, diâmetro de copa foram medidos diretamente com a trena na mesma época. Definiu-se a altura do arbusto como a distância entre o ponto mais alto da copa e o solo e a altura do tronco, como a distância entre o ponto de inserção do ramo mais baixo e o solo. Obteve-se a área foliar específica (AFE $-\mathrm{m}^{2} \cdot \mathrm{kg}^{-1}$ ), dividindo-se a área foliar de 10 folhas coletadas ao acaso, com três repetições por linha, por sua massa seca em estufa a $75^{\circ} \mathrm{C}$ até peso constante.

As características da copa do cafeeiro foram mensuradas de acordo com a metodologia proposta por Leong (1980), sendo essas: 1 1 altura da copa - a diferença entre as medidas de altura da árvore e altura do tronco; $2 \bullet$ porcentagem de copa - é a porcentagem da altura da copa sobre a altura da árvore; $3 \bullet$ abertura da copa - é a porcentagem do diâmetro médio da copa sobre a altura da árvore; 4 • razão de preenchimento da copa - é o quociente entre o diâmetro médio e o comprimento da copa, e indica o grau de arredondamento da copa; 5 • projeção da copa - é a porcentagem do diâmetro médio da copa sobre o diâmetro do tronco; $6 \bullet$ volume da copa - calculado também se considerando um formato cônico; $7 \bullet$ densidade foliar - o quociente entre a área foliar total pelo volume da copa

Mediu-se todas as árvores sombreadoras com o auxílio do altímetro de Haga, que mede a altura por hipsometria e a largura de suas copas, com uma trena para cálculo da radiação disponível à cultura intercalar como descrito na equação 1 . 
A condição de luz acima do dossel dos cafeeiros foi medida continuamente por tubos solarímetros (TS-UM-3, Eijkelkamp) instalados nas mesmas distâncias avaliadas e conectados a um sistema de aquisição de dados (Delta-T Devices), instalado no campo experimental. Essas medições permitiram a estimativa da transmissão e absorção de luz pelas árvores e sua disponibilidade ao cafeeiro.

Utilizou-se o modelo matemático (equação 1) para estimar a irradiância (Ir) que atingiu as entrelinhas da cultura em renque e confrontar com os resultados experimentais.

\section{3 Resultados e Discussão}

A Figura 2 apresenta os dados de radiação solar coletados durante a execução do experimento. Cada ponto refere-se à integral da radiação solar $\left(\mathrm{MJ} \cdot \mathrm{m}^{-2} \cdot \mathrm{dia}^{-1}\right)$ disponível no respectivo dia. A radiação disponível aos cafeeiros submetidos às diferentes condições (distâncias da borda da cultura de árvores: (dentro) -13,7; -10,3; -5,7; -2,3 m; (ao lado) 1,$5 ; 4,9 ; 8,3 ; 11,7 ; 15,1 ; 18,5 \mathrm{~m}$ e em monocultivo), em termos porcentuais foi de $25 \% ; 30 \% ; 35 \% ; 40 \% ; 45 \% ; 80 \% ; 90 \% ; 95 \%$, e cerca de100\% para as 3 posições mais distantes respectivamente.

A Figura 3 apresenta a fração da radiação disponível, bem como a radiação estimada pelo modelo matemático utilizado (Equação 1). Tal modelo somente pode ser utilizado em situações nas quais o dossel das árvores ainda não está completamente fechado (Goudriaan, 1977). Dessa maneira somente foi simulada a radiação disponível aos cafeeiros que se encontravam ao lado do seringal. A radiação disponível (fração transmitida) às plantas sob o dossel fechado pode ser calculada pela equação de Monsi \& Saeki (1953), derivada da lei de extinção de radiação de Beer-Bouguer-Lambert (Vianello \& Alves, 2000). Tal equação pode ser utilizada para a estimativa imediata do IAF de culturas sob diferentes condições de cultivo, ou para estimar a radiação disponível como proposto por Villa Nova et al. (2003). Observou-se que o modelo ajustou-se bem aos valores medidos nos diversos dias. Estes resultados estão de acordo com aqueles obtidos por Bernardes et al. (1998b) e Righi (2000), que observaram boa 
aproximação entre os valores medidos e aqueles estimados pelo modelo nos SAFs em renque de seringueiras e soja e de seringueiras e feijoeiro, respectivamente.

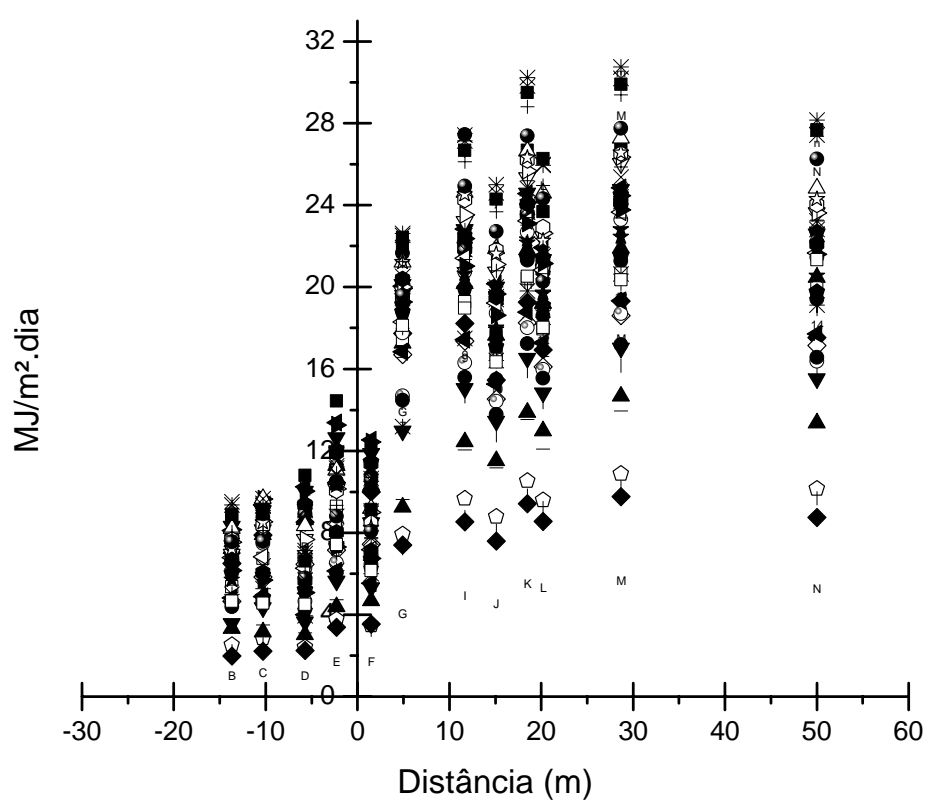

Figura 2 - Radiação (MJ.m ${ }^{-2} \cdot$ dia $^{-1}$ ) disponível aos cafeeiros medida com os tubos solarímetros (TS-UM-3, Eijkelkamp) em função da distância das árvores sombreadoras. Distâncias negativas referem-se a posições no interior do seringal. Cada ponto refere-se a integral da radiação disponível em um único dia

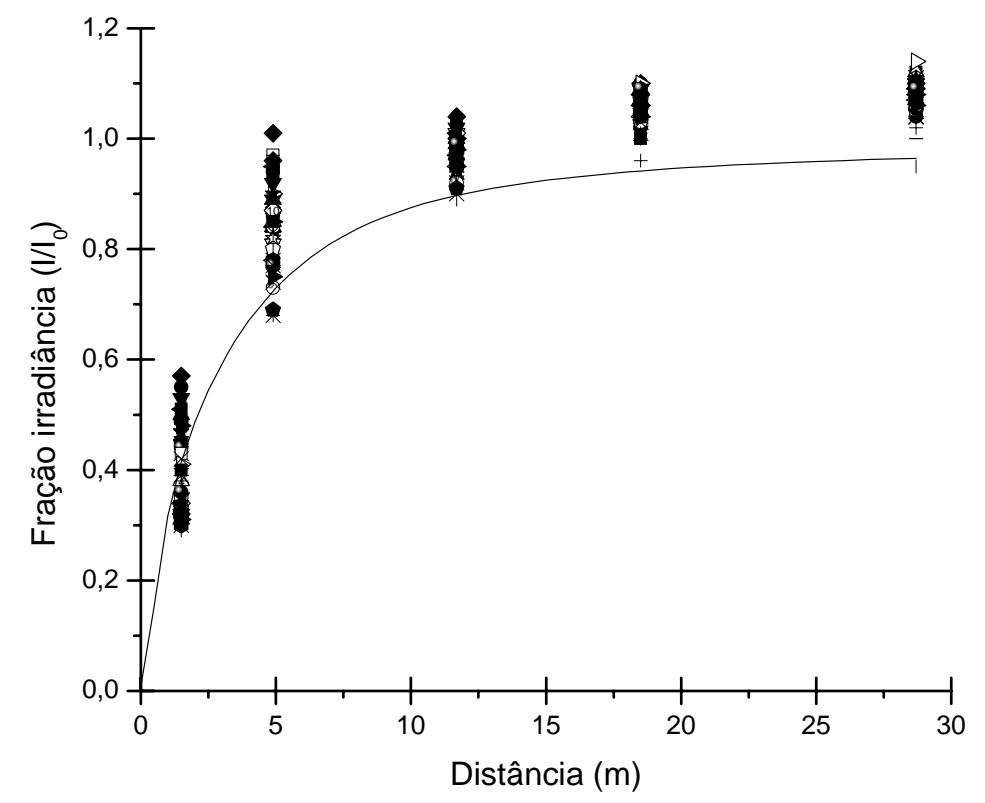

Figura 3 - Fração da irradiância disponível aos cafeeiros em função da distância das árvores sombreadoras. A linha refere-se à fração calculada pelo modelo matemático de Goudriaan (1977) 
Apesar dos cafeeiros apresentarem clara tendência em aumentar sua área foliar específica (AFE $-\mathrm{m}^{2} \cdot \mathrm{kg}^{-1}$ ) sob condições de sombreamento (Figura 4), isso não foi suficiente para igualar a área foliar total (AFT) àquelas dos cafeeiros nas condições mais iluminadas. O maior valor de AFE obtido $(16,69)$ foi cerca de $80 \%$ superior ao menor valor encontrado $(9,17)$, onde a planta recebia o total da radiação disponível monocultivo. Tal adaptação é freqüentemente observada e comentada por diversos autores (Righi, 2000; Ong et al., 1996; Evans et al., 1988; Esau, 1977; Pereira, 2002; Morais et al., 2003), como sendo uma das principais razões de sucesso das plantas ao adaptarem-se a ambientes com pouca disponibilidade de luz. De outra maneira, Pinto (2002) não encontrou diferença significativa do AFE em cana-de-açúcar em função do sombreamento, podendo ser algo característico de plantas de ciclo $\mathrm{C}_{4}$ que são mais adaptadas a altas irradiâncias.

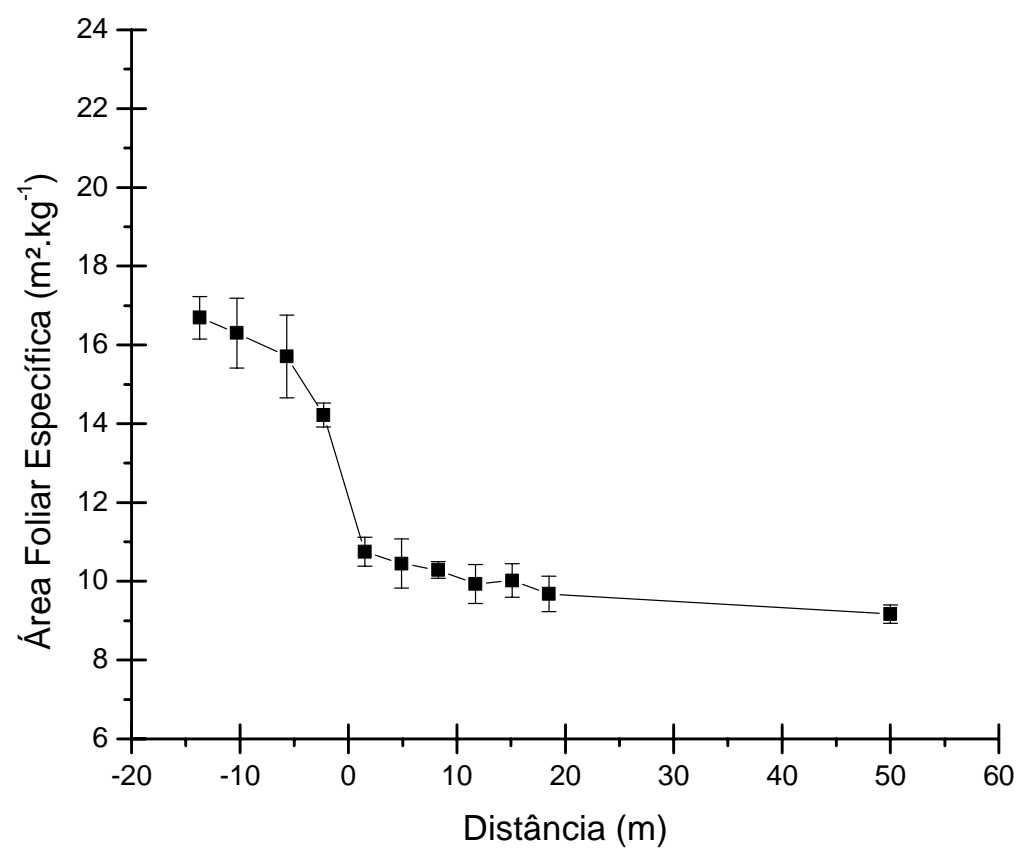

Figura 4 - Área foliar específica (AFE - $\mathrm{m}^{2} \cdot \mathrm{kg}^{-1}$ ) de cafeeiros em função da distância das árvores de seringueira

Interessante notar que apesar da grande diferença encontrada entre os valores extremos de área foliar total (variando de 5370 a $22617 \mathrm{~cm}^{2}$ - cerca de quatro vezes maior) (Figura 5a), o IAF foi semelhante em todas as posições no interior do seringal, 
como também a partir da distância de $4,9 \mathrm{~m}$ das seringueiras com cerca de $80 \%$ da luz disponível, na direção do monocultivo. Na distância de $1,5 \mathrm{~m}$, com cerca de $45 \%$ da irradiância, o valor do IAF encontrado foi intermediário (Tabela 1). Encontrou-se o mesmo padrão de variação para a área foliar total, porém com um súbito aumento nas primeiras posições ao lado das seringueiras (1,5 e 4,9 m). Ambas as variáveis apresentaram correlações lineares com a distância das seringueiras altamente significativas (ver anexo - tabela 1) para o teste F. 
Tabela 1 - Valores dos parâmetros avaliados no cafeeiro (Coffea arabica L.), cultivar cv. Obatã, IAC - 1669-20, distância das árvores, medida a partir da primeira fileira de seringueiras interfaceando o cafezal (distância zero) (as distâncias negativas referem-se ao interior do seringal e as positivas ao seu distanciamento em direção ao monocultivo de café); fração da irradiância $\left(\mathrm{I} / \mathrm{I}_{0}\right)$, a qual foi obtida dividindo o valor da irradiância medida nas respectivas distâncias (I) pelo valor da irradiância medida acima da cultura $\left(\mathrm{I}_{0}\right)$; diâmetro do tronco a $5 \mathrm{~cm}$ do solo $(\mathrm{mm})$; altura da planta $(\mathrm{cm})$; altura do tronco (cm); diâmetro da copa $(\mathrm{cm})$; altura da copa $(\mathrm{cm})$ - é a diferença entre as medidas de altura da árvore e altura do tronco; arredondamento da copa ou razão de preenchimento da copa - é o quociente entre o diâmetro médio e o comprimento da copa e indica o grau de arredondamento da copa; índice de área foliar ( $\mathrm{m}^{2}$. folha $\mathrm{m}^{-2}$ solo); porcentagem de copa (\%) - é a porcentagem da altura da copa sobre a altura da árvore; abertura da copa (\%) - é a porcentagem do diâmetro médio da copa sobre a altura da árvore; projeção da copa $(\%)$ - é a porcentagem do diâmetro médio da copa sobre o diâmetro do tronco; volume da copa ( $\left.\mathrm{cm}^{3}\right)$, calculado considerando um formato cônico; e densidade foliar $\left(\mathrm{cm}^{2} / \mathrm{cm}^{3}\right)$ - é o quociente entre a área foliar total pelo volume da copa

\begin{tabular}{|c|c|c|c|c|c|c|c|c|c|c|c|c|c|}
\hline $\begin{array}{l}\text { Distância } \\
\text { (m) }\end{array}$ & $\begin{array}{c}\text { Fração } \\
\text { Irradiância } \\
\left(\mathbf{I} / \mathbf{I}_{\mathbf{0}}\right)\end{array}$ & $\begin{array}{c}\text { Diam. } \\
\text { Tronco } \\
(\mathrm{mm})\end{array}$ & $\begin{array}{c}\text { Altura } \\
\text { Planta } \\
\text { (cm) }\end{array}$ & $\begin{array}{c}\text { Altura } \\
\text { Tronco } \\
\text { (cm) }\end{array}$ & $\begin{array}{l}\text { Diâmetro } \\
\text { Copa (cm) }\end{array}$ & $\begin{array}{c}\text { Altura } \\
\text { da Copa } \\
\text { (cm) }\end{array}$ & $\begin{array}{l}\text { Arredonda/o. } \\
\text { Copa }\end{array}$ & $\begin{array}{c}\text { IAF } \\
\left(\mathrm{m}^{2} / \mathrm{m}^{2}\right)\end{array}$ & $\begin{array}{c}\text { (\%) } \\
\text { de } \\
\text { copa }\end{array}$ & $\begin{array}{c}\text { Abertura } \\
\text { da copa } \\
(\%)\end{array}$ & $\begin{array}{c}\text { Projeção da } \\
\text { copa (\%) }\end{array}$ & $\begin{array}{l}\text { Volume de } \\
\text { copa }\left(\mathrm{cm}^{3}\right)\end{array}$ & $\begin{array}{c}\text { Densidade } \\
\text { foliar } \\
\left(\mathrm{cm}^{2} / \mathrm{cm}^{3}\right)\end{array}$ \\
\hline$-21,7$ & - & 11,72 & 54,50 & 24,70 & 60,35 & 29,80 & 2,03 & 1,97 & 54,41 & 110,17 & $5.131,03$ & $30.716,22$ & 0,21 \\
\hline$-18,3$ & - & 11,38 & 57,25 & 22,83 & 74,04 & 34,42 & 2,18 & 1,83 & 60,20 & 129,52 & $6.529,24$ & $50.111,49$ & 0,16 \\
\hline$-13,7$ & $25 \%$ & 12,48 & 56,95 & 23,89 & 72,39 & 33,07 & 2,31 & 2,00 & 57,74 & 127,86 & $5.812,54$ & $46.453,78$ & 0,20 \\
\hline$-10,3$ & $30 \%$ & 13,14 & 58,18 & 25,02 & 75,91 & 33,16 & 2,47 & 1,97 & 56,48 & 131,63 & $5.800,47$ & $50.858,10$ & 0,20 \\
\hline$-5,7$ & $35 \%$ & 14,11 & 59,04 & 25,60 & 76,83 & 33,44 & 2,47 & 1,96 & 56,28 & 131,19 & $5.448,60$ & $53.600,82$ & 0,19 \\
\hline$-2,3$ & $40 \%$ & 15,70 & 64,17 & 25,75 & 81,48 & 38,42 & 2,42 & 1,91 & 59,15 & 128,20 & $5.226,27$ & $68.418,93$ & 0,17 \\
\hline$\underline{1,5}$ & $\underline{45 \%}$ & $\underline{18,71}$ & $\underline{70,67}$ & $\underline{19,60}$ & $\underline{81,81}$ & $\underline{51,06}$ & $\underline{1,63}$ & $\underline{3,38}$ & $\underline{72,13}$ & $\underline{116,23}$ & $\underline{4.419,81}$ & $\underline{92.284,26}$ & $\underline{\mathbf{0 , 2 0}}$ \\
\hline 4,9 & $80 \%$ & 18,22 & 66,60 & 20,32 & 77,49 & 46,28 & 1,75 & 4,84 & 69,05 & 116,77 & $4.306,24$ & $77.219,10$ & 0,35 \\
\hline 8,3 & $90 \%$ & 18,18 & 63,33 & 21,49 & 73,28 & 41,84 & 1,83 & 3,65 & 65,50 & 115,84 & $4.041,10$ & $61.851,50$ & 0,28 \\
\hline 11,7 & $95 \%$ & 18,78 & 64,55 & 19,35 & 73,43 & 45,20 & 1,64 & 3,58 & 69,83 & 113,60 & $3.934,26$ & $66.679,70$ & 0,24 \\
\hline 15,1 & $100 \%$ & 17,68 & 60,00 & 21,92 & 69,05 & 38,08 & 1,85 & 4,18 & 63,04 & 115,10 & $3.908,75$ & $51.178,49$ & 0,35 \\
\hline 18,5 & $100 \%$ & 19,47 & 63,81 & 22,94 & 73,82 & 40,88 & 1,88 & 4,97 & 63,41 & 116,12 & $3.799,66$ & $62.501,86$ & 0,39 \\
\hline 21,9 & $100 \%$ & 16,64 & 53,75 & 21,58 & 60,71 & 32,17 & 2,10 & 4,45 & 59,12 & 113,69 & $3.659,29$ & $32.419,45$ & 0,49 \\
\hline Monocultivo & $100 \%$ & 18,59 & 61,16 & 19,38 & 71,73 & 41,78 & 1,74 & 4,27 & 68,23 & 117,76 & $3.897,39$ & $57.430,59$ & 0,31 \\
\hline
\end{tabular}


A densidade foliar ( $\mathrm{cm}^{2}$ folha. $\mathrm{cm}^{-3}$ copa) foi muito superior nos cafeeiros, que receberam cerca de $100 \%$ da radiação incidente, sendo no caso extremo duas vezes maior que nas plantas mais sombreadas. A maior densidade foliar (Tabela 1) e o maior número de folhas (Figura 5 b) nas plantas mais iluminadas comprovam a proximidade entre as folhas na copa e a barreira formada frente à alta radiação incidente. De outro modo, os cafeeiros em sua posição mais sombreada (interior do seringal, em que recebeu somente cerca de $25 \%$ da radiação) apresentaram folhas muito maiores e espaçadas umas das outras. Nas posições mais iluminadas $\left(100 \% \mathrm{I}_{0}\right)$, as folhas apresentaram uma área média ao redor de $45 \mathrm{~cm}^{2}$, enquanto que nas mais sombreadas $\left(25 \% \mathrm{I}_{0}\right)$, ao redor de $55 \mathrm{~cm}^{2}$. Nestas últimas, o aumento da AFE não foi suficiente para igualar a área foliar total, nem o IAF das plantas mais expostas à radiação, com conseqüente redução da cobertura do solo e interceptação da radiação. Tais reduções levaram inexoravelmente a um menor crescimento e acúmulo de matéria seca.

Os resultados obtidos concordam com Russell et al., (1989) que afirmam que onde a densidade foliar é menor existe uma alta probabilidade de um raio passar através de espaços na copa sem ser interceptado. De outro modo, sob maiores densidades, a luz não seria capaz de passar às camadas mais baixas, sendo absorvida ou espalhada pelas folhas. Robledo (1979) encontrou que os cafeeiros a pleno sol formam uma camada externa de folhas que absorve cerca de $90 \%$ da radiação incidente, ficando uma porcentagem mínima disponível às camadas mais internas (cerca de 5\%). O mesmo comportamento foi observado por Sakamoto \& Shaw (1967) nos dosséis de soja, e por Alvim (1977) com cacaueiro. Kumar (1978) também chega a conclusões similares com cafeeiros em alta densidade de plantio (mais que 15.000 plantas/ha).

Todos os demais parâmetros avaliados acompanharam similarmente a mesma tendência observada para o IAF, apresentando súbito aumento quando os cafeeiros passaram a receber cerca de $45 \%$ da radiação disponível que ocorreu já na primeira posição dos cafeeiros a $1,5 \mathrm{~m}$ de distância das árvores. Pode-se perceber assim a existência de dois patamares de valores, observando então uma aparente zona de transição que mostra ser o cafeeiro muito sensível à diminuição da luminosidade a partir de um determinado valor. 

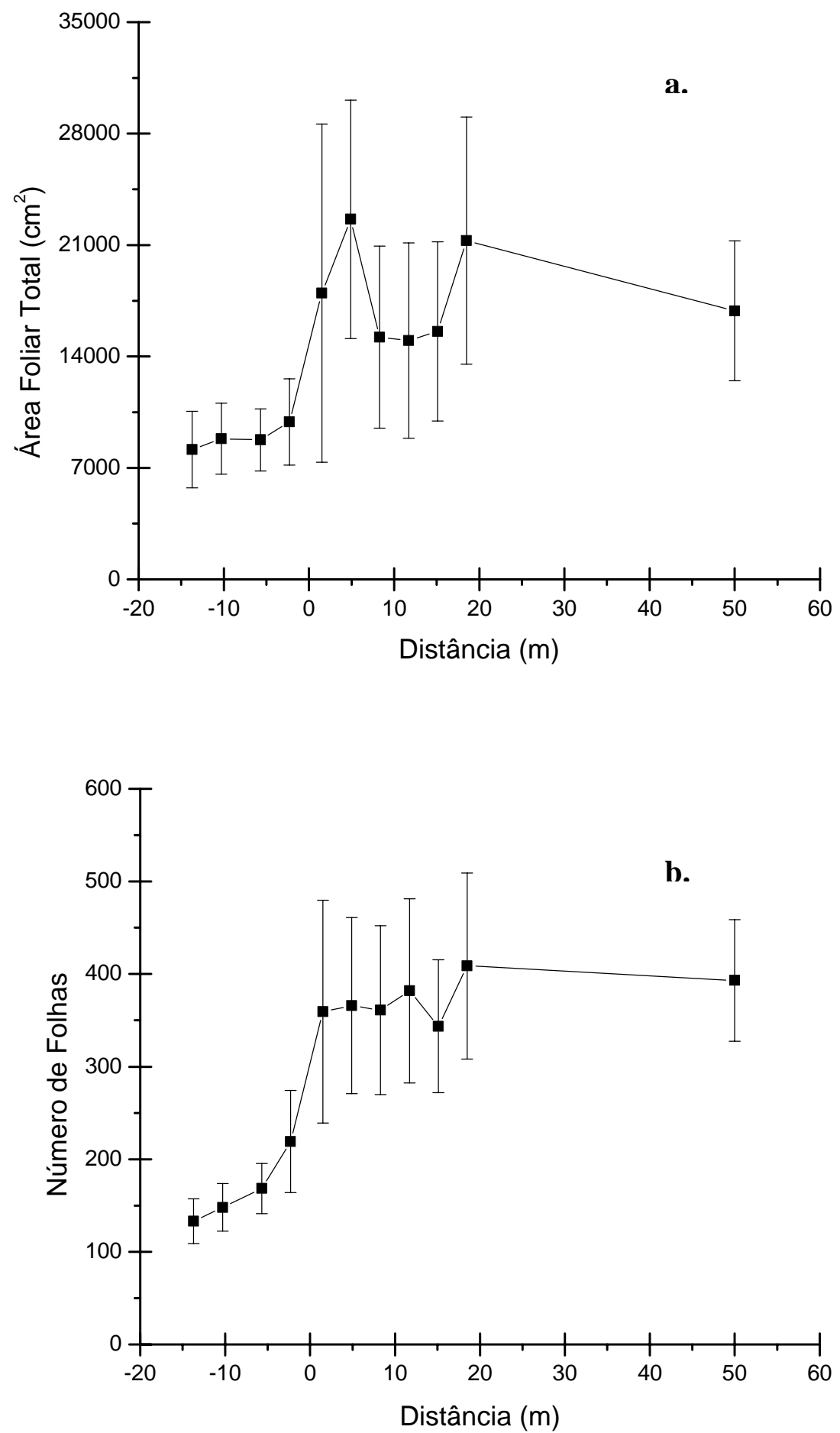

Figura $5 a$ - Área foliar total $\left(\mathrm{cm}^{2}\right)$ dos cafeeiros em relação a distância das seringueiras. $b$ - Número médio de folhas dos cafeeiros em relação a distância das seringueiras 
Os dados encontrados confirmam os resultados de Horn (1971), segundo o qual um maior número de camadas (IAF) numa copa resulta num maior potencial em fixação de carbono. Isto se deve a um incremento de tecido fotossintético que resulta, em um auto-sombreamento maior. Dessa forma a fotossíntese nas camadas mais inferiores é reduzida, aumentando a possibilidade de ocorrência de folhas expostas a irradiância abaixo do seu ponto de compensação lumínica. Portanto, o IAF depende da irradiância e da resposta fotossintética das folhas individuais. O tamanho da copa dependeria portanto da atenuação da radiação, estendendo-se até o ponto no qual a fotossíntese líquida seria igual a zero. Aumentos na irradiância propiciam maior quantidade de luz transmitida, o que favorece um incremento do IAF em plantas fortemente iluminadas. Assim, plantas expostas ao sol apresentam um arranjo difuso de suas folhas dispostas em várias camadas, enquanto que nas muito sombreadas suas folhas estariam dispostas em camadas mais uniformes (Horn, 1971). O baixo auto-sombreamento teria um grande impacto no balanço de carbono, principalmente em ambientes com irradiância próxima ao ponto de compensação (Givinish, 1984).

Devido ter-se calculado o IAF com base na área de projeção das copas, que foi ligeiramente menor nas posições mais sombreadas, pode-se observar claramente que não houve um aumento da área recoberta pela cultura, dada pelo diâmetro de copa, com o aumento da irradiância ou vice-versa. Os maiores diâmetros de copa $(81,48$ e $81,81 \mathrm{~cm})$ foram observados na interface do seringal nas distâncias $-2,3$ e $1,5 \mathrm{~m}$.

A abertura de copa dos cafeeiros (diâmetro de copa por altura total da planta) não diferiu muito nas posições avaliadas. Esse parâmetro pode ser conservativo, apesar de apresentar uma tendência de aumento quando sombreado (valores máximos ao redor de 130 na sombra contra valores ao redor de 115 nas plantas mais expostas ao sol) (Tabela 1). A abertura de copa aproximou-se do predito por King (1981) e observado por Givinish (1986). Apesar dos cafeeiros encontrarem-se em ambiente com redução na disponibilidade lumínica e ainda possuírem espaço suficiente entre linhas, o que favoreceria um maior aumento na abertura de copa, as plantas já se tocavam na linha de plantio, obrigando-as a um crescimento em altura.

A nítida redução da projeção de copa dos cafeeiros com o distanciamento das árvores deveu-se, muito mais, ao incremento acentuado do diâmetro de seu tronco no 
mesmo sentido - passando de valores ao redor de 11,38 nas posições mais sombreadas para 19,47 mm nas mais iluminadas, do que a diferenças no diâmetro de copa (Tabela 1).

Os cafeeiros apresentaram clara variação na arquitetura da copa, principalmente em sua componente vertical como observado nas diferenças em altura de copa, crescendo com a aproximação das árvores sombreadoras. A porcentagem de copa evidencia a maior capacidade de investimento das plantas mais iluminadas na captura e utilização da energia radiante. $\mathrm{O}$ mesmo padrão de aumento foi seguido no volume de copa, havendo, porém, uma grande inflexão nas distâncias intermediárias, onde o maior volume apresentado foi a $1,5 \mathrm{~m}\left(92.284 \mathrm{~cm}^{3}\right)$. Tais resultados evidenciam a plasticidade da arquitetura de copa do cafeeiro sob diferentes disponibilidades de luz, mostrando padrões diversos de interceptação e uso da luminosidade.

Devido ao crescimento vertical imposto pela presença de plantas vizinhas e a redução da luminosidade disponível aos cafeeiros sob a influência das seringueiras, a inserção do ramo mais baixo (dada pela altura do tronco) foi mais alta nas plantas sombreadas (ao redor de 24,5 cm), revelando uma diminuição gradativa em direção ao monocultivo, onde a inserção do ramo mais baixo deu-se à cerca de $19 \mathrm{~cm}$ do solo. Tal fato, pode ser atribuído aos custos energéticos envolvidos, que impossibilita a sua manutenção. Bierhuizen et al. (1971) encontraram que o ponto de compensação do cafeeiro é de $0,3 \mathrm{cal} \cdot \mathrm{cm}^{-2} \cdot \mathrm{min}^{-1}$. A altura do tronco, contribui assim, ainda mais com aumentos na abertura de copa e o distanciamento do formato mais arredondado da copa dos cafeeiros a pleno sol (valores próximos a 1,5) que tendeu a uma configuração oblonga nas posições mais sombreadas (valores ao redor de 2,5) (Tabela 1).

A perda dos ramos da saia do cafeeiro é muito freqüente em cafezais em espaçamentos adensados e super adensados ou quando excessivamente sombreados, quer seja devido ao auto-sombreamento ou em razão das árvores. As folhas destes ramos, por se encontrarem abaixo de seu ponto de compensação, são descartadas pela planta (Hopkins, 1995). Como não há reposição de ramos plagiotrópicos (ramos de produção, também denominados ramos da saia do cafeeiro), pelo cafeeiro, mesmo 
com aumentos substanciais da irradiância, tal perda configura uma anomalia na planta, havendo então perda significativa na produtividade.

Monsi e Saeki (1953) demonstraram que o coeficiente de extinção da radiação (k) tende a ser maior para espécies de folhas largas e dispostas horizontalmente $(\mathrm{k} \approx 0,6$ a 0,9$)$ do que para folhas pequenas e eretas $(\mathrm{k} \approx 0,3$ a 0,5$)$. É de se esperar que nas condições sombreadas o coeficiente de extinção da luz fosse superior ao encontrado nas plantas mais iluminadas, porém tal fato ainda carece de maiores estudos. Robledo (1979) observou valores de $\mathrm{k}$ ao redor de $0,41 \pm 0,15$ no interior da copa dos cafeeiros, e que a extinção da radiação somente deu-se de maneira exponencial redor do meio dia, quando o cafeeiro apresentou o menor albedo. Tais fatos indicam uma grande absorção de energia nestes horários.

O cafeeiro demonstra reunir várias características que lhe possibilita uma grande atenuação da radiação disponível. Cannel (1976) observou que o cafeeiro utiliza grande parte de sua matéria seca para incrementar a área foliar; as plantas possuem boa transmissão de luz no interior da copa, os galhos superiores com pequenos ângulos em relação à normal, as folhas são distribuídas em grandes distâncias verticais e; a estrutura é cônica, resultando em pouco sombreamento nas camadas inferiores.

Além do IAF, um importante aspecto da geometria de copa determinando o total de fixação de carbono é sua eficiência mecânica, a fração de energia alocada à folhagem em relação aos demais órgãos não produtivos. As copas desempenham tanto um papel na captura e conversão de energia como também servindo de instrumento de interferência competitiva (Givinish 1988). Para este autor, o custo de manutenção de uma folha deve considerar além de seu ponto de compensação, os custos de formação das folhas, ramos e raízes, aumentando em muito o ponto de compensação ecológico. Desta maneira tais custos de suporte, e portanto a altura da planta, são importantes na determinação de sua habilidade em persistir sob sombra. Givnish (1988) re-analisou os dados de Björkman et al. (1972) e sugeriu expressar a fotossíntese e a respiração em função da massa foliar ou do conteúdo de proteína, de modo, a incorporar os custos de construção e acessar sua adaptação aos níveis de irradiância, o que fica mais aparente do que se expresso por área foliar. Agindo dessa forma, as altas taxas de retorno sob baixas irradiâncias das folhas adaptadas a estas 
condições ficam evidentes. Por esta razão, não surpreende o fato de as copas das plantas sob radiação direta, com folhas adaptadas expostas aos diversos ambientes lumínicos, ter cada folha individual trabalhando em sua máxima eficiência. Assim, devido ao maior tecido fotossintético do que as plantas de sombra, as plantas de sol (como nesse caso com o dobro do IAF) apresentaram maior fotossíntese bruta e acúmulo de matéria seca.

Os resultados apresentados evidenciam a diferença de comportamento do cafeeiro quanto a padrões de interceptação e atenuação da energia radiante e a alocação dos compostos fotossintetizados nos diversos ambientes. O resumo da análise estatística apresentada na Tabela 1 do Anexo mostra que somente para as variáveis altura de copa e porcentagem de copa não apresentou correlação linear significativa com a distância das árvores para o teste F. O volume de copa e a altura total apresentaram correlação significativa ao nível de 10\%, enquanto que as demais variáveis apresentaram correlações altamente significativas (menor que 1\%).

A Figura 6 apresenta a correlação entre a matéria seca total produzida versus fração da radiação solar disponível. Observou-se que os cafeeiros apresentaram bom crescimento sob cerca de $45 \%$ da radiação total disponível, a 1,5 m de distância das árvores de seringueira. Os resultados obtidos diferem daqueles amplamente comentados quanto a sua proporcionalidade (Pereira, 2002; Righi, 2000; Confalone, et al., 1997; Russell et al., 1989). Tal fato, provavelmente, deve-se a que os estudos anteriores tratam de culturas com rápido fechamento de dossel vegetativo, enquanto que no presente caso o fechamento do dossel deu-se parcialmente. Assim, a interceptação da radiação disponível ocorreu de maneira muito diferente nas posições avaliadas, não se encontrando uma boa correlação.

Outra possibilidade para explicar a queda abrupta do total de matéria seca acumulada, e portanto a diminuição da sua relação com a radiação disponível nos cafeeiros a $-5,7 \mathrm{~m}$ de distância das árvores (cerca de 35\% da irradiância), pode ser atribuída à redução na disponibilidade da radiação fotossinteticamente ativa (RFA) pois os pés de café encontravam-se inteiramente sob o dossel das seringueiras que atuam como um filtro (Russell et al., 1989; Larcher, 1975). Porém, mais do que tal diminuição, é importante ressaltar o provável aumento na eficiência de captura da 
radiação e conversão pelas plantas a $1,5 \mathrm{~m}$ de distância das árvores (com cerca de $45 \%$ da irradiância).

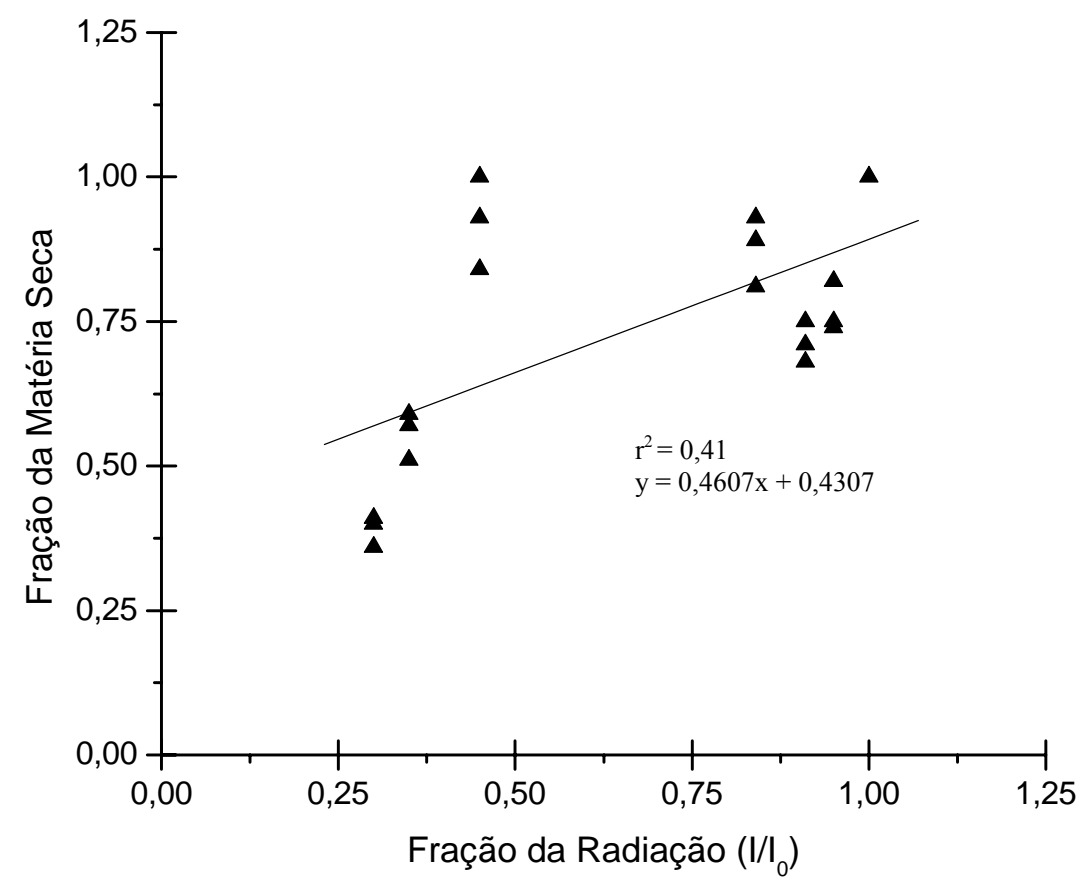

Figura 6 - Fração da matéria seca acima do solo em função da fração da radiação disponível (I// $\left.\mathrm{I}_{0}\right)$

Para Russell et al., (1989) a resposta linear do crescimento por RFA absorvido é esperada conquanto sua copa não está exposta a irradiâncias saturantes durante parte significativa de sua estação de crescimento. Porém, muitas copas nunca se aproximam da saturação. A questão é: teriam as plantas a 1,5 m de distância das árvores alcançado a saturação de suas copas com apenas $45 \%$ da irradiância disponível? Tais valores de irradiância seriam próximos ao da saturação para folhas isoladas (cerca de $2 / 3$ da irradiância em um dia claro de verão), longe de ser aquela normalmente necessária para a saturação de uma copa. Caso tal hipótese fosse comprovada, retirando-se os dados acima do ponto de saturação obter-se-ia uma correlação com muito melhor ajuste passando $\mathrm{r}^{2}$ de 0,41 para 0,96 .

Observou-se que o modelo de Gompertz apresentou um bom ajuste aos dados coletados, obtendo-se um $\mathrm{r}^{2}$ de 0,74 (Figura 7). Por este modelo pode-se notar claramente que o cafeeiro atinge sua saturação com 45\% da irradiância disponível, o que revelou ainda, uma correlação linear até atingir a saturação como apontado por 
Russell et al., (1989). A partir de 45\% da irradiância, os valores de matéria seca encontraram-se num mesmo patamar.

Este efeito de saturação pode ser também explicado pela limitação intrínseca do aparato fotossintético que não responde com aumentos da fotossíntese bruta, a partir da saturação, a incrementos na disponibilidade de radiação. Tal situação pode ser verificada pela estagnação dos valores de área foliar com o aumento da radiação (Figura 5a e b) e dos demais fatores fitométricos (Tabela 1).

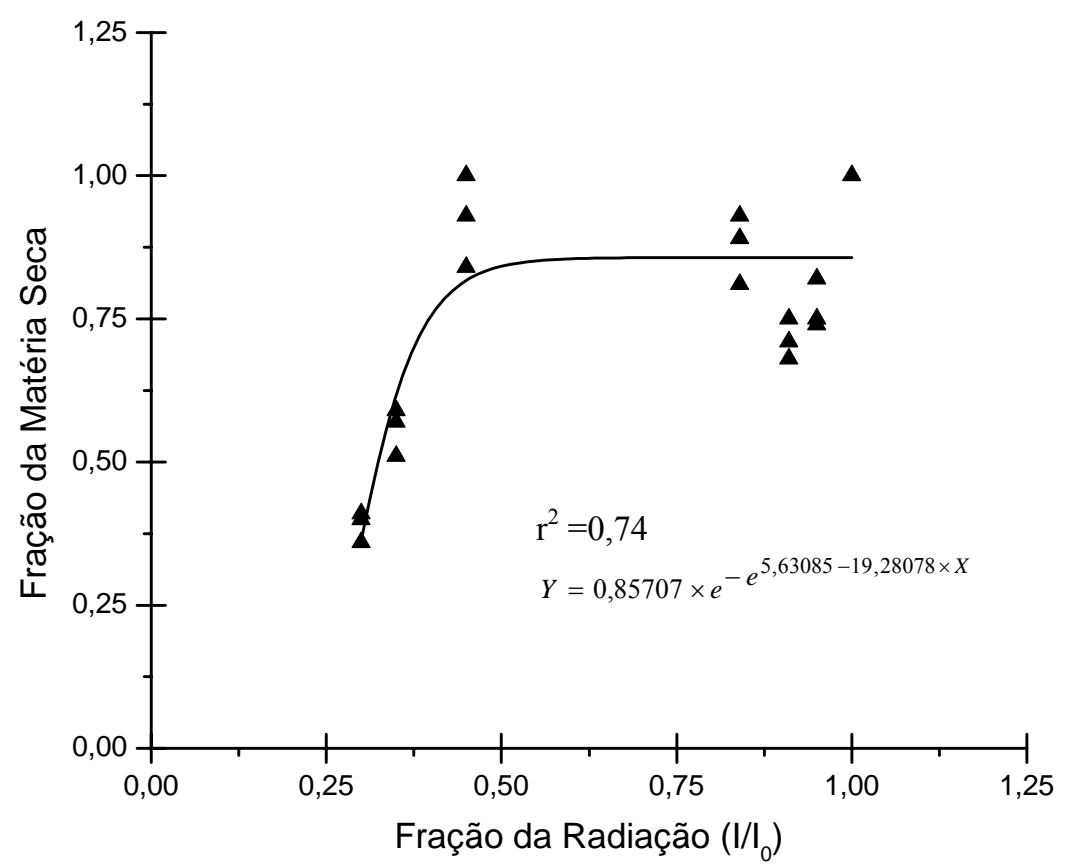

Figura 7 - Ajuste do modelo de Gompertz para a fração da matéria seca dos cafeeiros em função da fração da radiação disponível $\left(\mathrm{I} / \mathrm{I}_{0}\right)$

É plausível que a ausência de resposta em crescimento a partir da inflexão da curva $\left(45 \% \mathrm{I}_{0}\right)$ deva-se a um aumento da respiração. Tal elevação poderia ser em igual valor ao incremento da fotossíntese bruta e anularia qualquer possível aumento da fotossíntese líquida e portanto do crescimento dos cafeeiros sob maiores disponibilidades de irradiância.

O evidenciamento das razões da aparente ausência de resposta do cafeeiro a maiores disponibilidades de luz é digna de maiores investigações. 


\section{4 Conclusões}

O modelo matemático proposto por Goudriaan (1977) descreveu adequadamente a disponibilidade de luz à cultura intercalar, o que pode ser uma importante ferramenta no planejamento e análise de SAFs;

O cafeeiro mostrou boa plasticidade, apresentando recursos de adaptabilidade à redução na disponibilidade de luz com aumento da AFE, diminuição do IAF e da densidade foliar, modificações na geometria da planta e modo de interceptação e uso da radiação com menor arredondamento de copa, maior altura de tronco e menor volume de copa;

A cultura não apresentou uma boa correlação linear entre a fração de radiação disponível e a fração da matéria seca, devido provavelmente a saturação de sua copa com cerca de $45 \%$ da irradiância disponível. O modelo de Gompertz apresentou um melhor ajuste aos dados obtidos.

Não se observou queda no acúmulo de matéria seca com reduções de 100 a 45\% da irradiância disponível. Maior redução em sua disponibilidade ocasionou acentuada diminuição do acúmulo de matéria seca diretamente proporcional, bem como modificações em suas características morfológicas, dada a adaptação a estas condições.

$\mathrm{O}$ cultivo do cafeeiro em SAFs apresenta boa perspectiva devido à sua capacidade de adaptação a grandes reduções na disponibilidade de luz.

\section{4. 1 Considerações Finais}

É ainda grande a quantidade de publicações a respeito da influência da luz que não traz qualquer menção quanto à sua medição, limitando-se a estabelecer quanto à condição de sombreamento ou não. Salienta-se aqui a importância da quantificação da irradiância, pois esta é a principal fonte de energia que controla os processos fisiológicos e suas várias implicações sobre os sistemas de produção.

A adoção de SAFs pelos produtores de café pode significar um avanço desta cultura a regiões antes consideradas inaptas ou marginais, devido principalmente a redução do estresse por temperatura. Como os estudos sobre irradiância contêm um inevitável componente térmico (radiação infra-vermelha termal) é de senso comum 
entre os pesquisadores de que o cafeeiro não pode suportar altos níveis de irradiâncias. Tal fato não parece ser verdadeiro, uma vez que se pode encontrar muitas plantações de cafeeiros na zona equatorial, como no Quênia e na Etiópia, tanto quanto a temperatura do ar permita. Futuros trabalhos enfocando o papel da temperatura e suas relações nos processos fisiológicos parecem ser promissores tanto para o desenvolvimento dos SAFs como da cultura do cafeeiro. 


\section{USO DA ÁGUA POR CAFEEIROS EM UM SISTEMA AGROFLORESTAL COM SERINGUEIRAS}

\section{Resumo}

A captura e uso da água são essencialmente processos energéticos que podem ser largamente modificados pela porcentagem de cobertura do solo, tipo de planta, área foliar e sua distribuição, estádio fenológico e muitos fatores ambientais. Cafeeiros de um ano de idade (Coffea arabica L. cv. Obatã, IAC - 1669-20) foram submetidos a diferentes condições de sombreamento num experimento em Piracicaba-Brasil $\left(22^{\circ} 42^{\prime} 30^{\prime \prime} \mathrm{S}, 4^{\circ} 38^{\prime} 00^{\prime}\right.$ W - altitude $\left.546 \mathrm{~m}\right)$. Os cafeeiros em espaçamento $3,4 \times 0,9 \mathrm{~m}$ dentro e ao lado da cultura de seringueira (Hevea brasiliensis Müell. Arg.) foram avaliados em função das seguintes distâncias das árvores, a contar da borda: (dentro) -5,7 m, (ao lado) 1,5; 4,9; 11,7 m e em monocultivo. Em dezembro/2002 e fevereiro/2003 - época de verão - a luz refletida e transmitida aos cafeeiros foi mensurada utilizando-se tubos solarímetros (Delta-T) nas ruas de plantio. Nas mesmas posições o fluxo de seiva foi medido pela técnica do balanço de calor (Dynamax Inc.). A disponibilidade lumínica aos cafeeiros em relação às distâncias foi de: $35 \% ; 45 \% ; 80 \% ; 95 \%$ e $100 \%$. A transpiração por área foliar dos cafeeiros diminuiu com o sombreamento, o que é vantajoso na conservação da água no solo. Entretanto o sombreamento elevou a perda de água por unidade de área foliar e energia incidente, indicando assim uma possível menor eficiência do uso da água. Por outro lado, plantas em monocultivo (pleno sol) apresentaram a menor perda de água por unidade de área foliar e energia incidente.

Palavras-chave: uso da água; eficiência; café, seringueira; luz; transpiração 


\section{COFFEE WATER USE IN AN AGROFORESTRY SYSTEM WITH RUBBER TREES}

\section{Summary}

Water uptake and use by plants are essentially energetic processes that can be largely modified by percentage of land cover; kind of plants; leaf area and its distribution; phenological stage and many environmental factors. One-year-old coffee plants (Coffea arabica L. cv. Obatã, IAC - 1669-20) were submitted to different shade conditions in an experiment in Piracicaba-Brazil $\left(22^{\circ} 42^{\prime} 30^{\prime}\right.$ S, $47^{\circ} 38^{\prime} 00^{\prime}$ W $\mathrm{W}$-altitude $546 \mathrm{~m}$ ). Coffee plants in spacing of 3.4 x $0.9 \mathrm{~m}$ inside and aside of a 12-year-old rubber crop (Hevea brasiliensis Müell. Arg.) were evaluated in function of the following distance from the trees, counting from the border: (inside) $5.7 \mathrm{~m}$, (aside) $1.5 ; 4.9 ; 11.7 \mathrm{~m}$ and in the coffee monocrop. In December/2002 and February/2003 - Summer - the reflected and transmitted light available to the coffee was measured using solarimeter tubes (Delta-T) at the rows of the coffee plantation. At the same positions the sap flow was measured by the technique of heat balance (Dynamax Inc.). Relative light availability was, respectively to those distances, 35\%; $45 \% ; 80 \% ; 95 \%$ and about $100 \%$. Transpiration per leaf area diminished with the shade, that is advantageous for the soil water conservation. In the meantime shade increased the water loss per leaf area per incident energy, thus indicating probably lower water use efficiency. On the other hand, plants in monocrop (full sun) performed the lowest water loss per unit of leaf area per incident energy.

Key-words: water use; efficiency; coffee, rubber; light; transpiration

\section{1 Introdução}

O SAF é um sistema de uso da terra, no qual árvores crescem em associação com outras culturas perenes ou anuais e/ou gado, em várias disposições no espaço e no tempo, utilizando práticas de manejo compatíveis com a população local. Neste sistema, há interações ecológicas e econômicas entre as árvores e as outras culturas, que resultam em algumas vantagens comparativas aos outros sistemas de agricultura (Nair, 1989; Young, 1989). Os SAFs podem propiciar maior eficiência e 
complementaridade espacial e temporal no uso dos recursos disponíveis à produção, sejam água, nutrientes, etc. A redução da densidade de plantio das árvores sombreadoras ou o consórcio com plantas tolerantes ao sombreamento e mais competitivas por água e nutrientes, podem elevar a eficiência dos SAFs incrementando a sustentabilidade na produção.

A presença de árvores em um sistema de produção pode alterar o balanço de radiação e o comportamento de ventos na área sob influência destas (Monteith et al., 1991; Brenner, 1996). As árvores atuam de três formas sobre o ambiente: i) sombreando parcial e temporariamente a cultura protegida; ii) competindo por água e nutrientes do solo e; iii) diminuindo a velocidade do vento. Desta maneira ocorrem modificações no microclima, que por sua vez, induzem alterações nos processos fisiológicos e nas características da cultura protegida (Leal, 1986). O efeito múltiplo destas mudanças modifica o balanço de energia disponível para o meio, alterando o uso da água, a produtividade e o ciclo das plantas sob essa nova condição (Baldy \& Stigter 1993).

Fisiologistas e ecologistas há muito argumentam que o entendimento dos processos e mecanismos envolvidos na captura dos recursos e seu uso, e das suas interações com o ambiente é de fundamental importância para o desenvolvimento de sistemas produtivos sustentáveis (Willey \& Reddy, 1981; Ong et al., 1996).

As espécies em SAF compartilham de muitos processos em comum, incluindo competição, modificação ambiental, transferência de nitrogênio às não leguminosas associadas. Ong et al., (1996) relatam que as interações abaixo do solo têm-se mostrado importantes em SAFs, devendo-se despender especial atenção aos estudos de eficiência da utilização dos recursos naturais. Segundo Sá (1994), os SAFs proporcionam grande melhoria no uso da água em regiões semi-áridas e nos trópicos áridos, onde sua disponibilidade é sazonal. A maioria dos sistemas de culturas anuais usa somente 30 a $35 \%$ da água da chuva. O restante é perdido por evaporação do solo, escorrimento superficial ou em umidade residual no final da colheita. SAFs oferecem a oportunidade de complementaridade espacial e temporal no uso da água, o que pode resultar em melhor aproveitamento desta, comparativamente às culturas solteiras (Ong et al. 1996). 
Nuberg et al., (2002) não observaram qualquer benefício às culturas intercalares devido à melhoria das condições micrometeorológicas nas regiões tropicais úmidas. Da mesma forma, Crawford et al. (1998) apontam exemplos de rendimentos de culturas intercalares, não sendo reduzidos por competição com as árvores em regiões com alta pluviosidade. Por outro lado, vários autores (Kang, 1993; Sanchez, 1995; Govindarajan et al., 1996 e Stirzaker et al., 2002) apontam que em ambientes com limitações hídricas, SAFs em renques tendem a ter efeito negativo na produção de grãos das culturas associadas mais freqüentemente do que apresentam um efeito neutro ou positivo. Ong (1994) aponta que o foco na utilização de SAFs em renques deveria ser portanto em minimizar os efeitos negativos ao invés de procurar súbitos aumentos de produção.

Nos vários tipos de vegetação encontrados na natureza, a produtividade está intimamente relacionada com a água disponível para as plantas (Salisbury \& Ross, 1978). Dentre os vários fatores limitantes da produção vegetal, o déficit hídrico ocupa posição de destaque, pois além de afetar diretamente as relações hídricas nas plantas, alterando-lhes o metabolismo, é fenômeno que ocorre em grandes extensões de áreas cultivadas. Muitas plantas, segundo Boyer (1982), apresentam mecanismos capazes de diminuir os efeitos da falta de água no solo e que podem ser transmitidos geneticamente.

Mazzafera \& Carvalho (1987) apontam que é importante correlacionar a produtividade dos cafeeiros com as condições de deficiência hídrica, uma vez que, muitas progênies que apresentam tolerância à seca apresentam baixas produções. Os mesmos autores encontraram pequena redução na fotossíntese do cafeeiro sob potenciais hídricos de até $-2,0 \mathrm{MPa}$, sugerindo que o cafeeiro é uma espécie relativamente resistente à seca.

O cultivo de café sombreado no Brasil não se generalizou devido ao fato da baixa produtividade do cafeeiro ter sido atribuída ser à concorrência por água entre este e as árvores sombreadoras (Franco, 1963).

Para compreender a dinâmica na transferência da água em comunidades florestais, a medida da transpiração constitui-se em um elemento essencial (Granier, 1985). Além disso, essa desempenha importante papel no balanço energético da planta com o meio e a absorção de dióxido de carbono para a fotossíntese 
(Angelocci, 2002). A determinação do fluxo de água no xilema merece grande atenção, principalmente em árvores, pois sua medição em campo é sempre difícil. Dentre os métodos que podem ser utilizados, o método do Balanço de Calor balanceamento do calor dissipado em um certo volume de caule ou ramo através do fluxo contínuo e constante de calor - vem sendo utilizado com sucesso (Sakuratani, 1981; Valancogne \& Nasr, 1989; Weibel \& Vos, 1994).

As trocas energéticas e de gases entre a planta e seu ambiente são realizadas principalmente por suas folhas, que são suportadas e dispostas sob ramos e troncos, de modo que tais transferências ocorram de maneira eficiente (Campbell e Norman, 1989). Quando a abertura estomática é reduzida, a transpiração é modificada em maior grau do que o fluxo de $\mathrm{CO}_{2}$ e, conseqüentemente, a fotossíntese. Somente em casos extremos, onde a excessiva perda de água tende a comprometer as demais funções fisiológicas da planta, os estômatos cerram-se, cortando as trocas gasosas (Angelocci, 2002). A habilidade de uma planta em moderar a perda de água, enquanto mantém uma absorção suficiente de $\mathrm{CO}_{2}$ para fotossíntese, pode ser analisada por meio de um parâmetro denominado razão de transpiração (Taiz \& Zeiger, 1991), ou requerimento de água (Kramer \& Boyer, 1995), definido como a quantidade de água transpirada pela planta dividida pela quantidade de dióxido de carbono assimilado pela fotossíntese. O inverso da razão de transpiração é denominado 'eficiência do uso da água' (EUA) (Taiz \& Zeiger, 1991). O EUA é, assim, definido como unidade de matéria seca produzida por planta, por unidade de água utilizada (Kramer \& Boyer, 1995). Portanto, sendo o EUA uma relação entre a absorção de $\mathrm{CO}_{2}$ (A) e transpiração $(\mathrm{T})$, pode-se dizer, a princípio, que se a disponibilidade de água é reduzida, os estômatos fecham-se e a transpiração diminui, aumentando o EUA (Taiz \& Zeiger, 1991). Há grandes evidências de que o EUA varia entre espécies, no mesmo ambiente, e entre climas para uma mesma cultura (Kramer \& Boyer, 1995). Vários estudos demonstram que em uma dada espécie, a relação transpiração/fotossíntese permanece grosseiramente constante com a variação da condutância estomática em resposta às mudanças na irradiância, umidade relativa, estresse hídrico, fertilidade do solo e concentração de $\mathrm{CO}_{2}$ (Farquhar, 1979; Hall \& Schulze, 1980; Field et al., 1982; Mooney et al., 1983). 
Givinish (1988) sugere que os estudos direcionados à adaptação das plantas à sombra devem ser direcionados às raízes, ramos e folhas e devem incorporar os efeitos do suprimento de água e nutrientes na determinação da habilidade das plantas em persistirem em um determinado ambiente.

Para Givinish (1988), os benefícios fotossintéticos resultantes dos aumentos na difusão do $\mathrm{CO}_{2}$ ao interior das folhas deve ser considerado em função dos seus custos energéticos associados a aumentos na perda de água. Os custos da transpiração devem considerar a redução da capacidade fotossintética do mesófilo devido à redução no potencial hídrico da folha, aumento na alocação dos recursos a tecidos não produtivos, como as raízes ou xilema e, se for o caso, uma redução do período da atividade fotossintética (Givinish \& Vermeij, 1976; Givinish, 1984).

Os custos de construção das folhas (C) são difíceis de se mensurar, pois não abrangem somente seus custos na fixação de carbono $(\mathrm{P})$ na síntese de seus vários componentes, mas também abrange os de construção e manutenção das raízes e ramos, necessários à obtenção dos nutrientes e água na síntese dos componentes das folhas (Mooney \& Gulmon, 1979). A taxa de retorno líquido por unidade de investimento no tecido foliar é um determinante importante na taxa de crescimento da planta (Givinish, 1988). Dessa maneira, o mesmo autor sugere que de um ponto de vista econômico, pode ser mais ilustrativo expressar a fotossíntese por unidade de massa (ou talvez por conteúdo de nitrogênio foliar), ao invés de por unidade de área. Os custos de construção das folhas por unidade de área devem aproximar-se da biomassa das folhas por unidade de área $\left({ }^{1} / \mathrm{AFE}\right)$, uma vez que estas não variem muito em composição (Osmond et al., 1980). Dessa maneira, a relação fotossíntese/custos de construção seria diretamente proporcional à fotossíntese por unidade de massa foliar (Givinish, 1988).

Uma melhor compreensão do comportamento ecofisiológico do cafeeiro em SAF e a pleno sol é de grande importância, visando incrementar a produtividade do sistema, bem como verificar a possibilidade de uso do cafeeiro como cultura complementar, otimizando, o uso dos recursos disponíveis.

Este estudo teve por finalidade o melhor entendimento do uso da água pelos cafeeiros frente às modificações das condições microclimáticas, devido à presença das árvores (sombreados) e sem sua interferência (pleno sol). 


\section{2 Material e Métodos}

O experimento foi conduzido no campo experimental do Departamento de Produção Vegetal da Escola Superior de Agricultura "Luiz de Queiroz" da Universidade de São Paulo (ESALQ/USP) em Piracicaba-SP (2242’30" S, 47³8'00" W - altitude $554 \mathrm{~m}$ ) durante o ano de 2002 e 2003.

O seringal foi plantado em 1991 no espaçamento de $8 \times 2,5 \mathrm{~m}$, com mudas enxertadas em sacolas plásticas com dois lançamentos foliares maduros do enxerto, cujos blocos experimentais foram compostos por árvores do mesmo clone - PB - 235. A cultura do cafeeiro, Coffea arabica L. cv. Obatã, IAC - 1669-20, foi plantada no espaçamento de $3,4 \times 0,9 \mathrm{~m}$ em janeiro/2002 sob o bosque de seringueiras, interfaceando as árvores e em monocultivo. As mudas tinham 9 meses de idade e eram oriundas de semeadura direta em sacolas plásticas com permanência em viveiro com sombrite apropriado. Por ocasião do experimento o cafezal encontrava-se com 1 ano de plantio.

O terreno com declividade variando de 0 a 1,5\%, constitui-se de um Nitossolo vermelho eutroférrico (Embrapa, 1999) (Terra Roxa Estruturada), eutrófico, horizonte A moderado e textura argilosa, classificação americana Kandiudalfic Eutrodox. A fertilidade do solo e a existência de sistema de irrigação instalado na área do ensaio evitaram limitações no crescimento e no desenvolvimento das plantas, além daquelas provenientes do tratamento experimental. Na implantação do cafeeiro foi realizada análise de solo, que serviu para as correções necessárias.

Avaliaram-se cafeeiros plantados em espaçamento de 3,4 x 0,9 m dentro e ao lado do seringal, estes últimos (primeira linha) simulando aléias duplas de seringueiras em espaçamento $8 \times 2,5 \mathrm{~m}$ e também o monocultivo no mesmo espaçamento. $\mathrm{O}$ experimento foi conduzido com 5 tratamentos - distância das árvores - sendo: (dentro) -5,7; (ao lado) 1,5; 4,9; 11,7 m e em monocultivo. A parcela experimental era constituída de uma área de $12,5 \times 32,8 \mathrm{~m}$, como está disposto no esquema das parcelas de amostragem (Figuras 2,3 e 4 - item 2.8.3). Todos os cafeeiros foram plantados no mesmo espaçamento e mantidos livres da competição com plantas daninhas. 
A cultura do cafeeiro foi irrigada por gotejamento. A evapotranspiração da cultura foi estimada pelo uso do tanque Classe A, da estação Meteorológica Principal do Departamento de Ciências Exatas da ESALQ-USP, localizada ao lado do experimento. A lâmina de irrigação foi calculada de acordo com o método proposto por Villa Nova \& Sentelhas (1999).

A área foliar total (AFT) de cada planta de cafeeiro foi obtida pela contagem do número de folhas multiplicado pelo tamanho da folha média corrigida. Encontrouse que a área da folha média equivale a $68 \%$ da área do retângulo calculado com base em suas medidas. A área foliar específica $\left(\mathrm{AFE}-\mathrm{m}^{2} \cdot \mathrm{kg}^{-1}\right)$ foi obtida dividindo-se a área foliar de 10 folhas coletadas ao acaso, com três repetições por linha, por sua massa seca em estufa a $75^{\circ} \mathrm{C}$ até peso constante.

A condição de luz acima do dossel dos cafeeiros foi medida continuamente por tubos solarímetros (TS-UM-3, Eijkelkamp) instalados nas mesmas distâncias avaliadas e conectados a um sistema de aquisição de dados (Delta-T Devices) instalado no campo experimental. Essas medições permitiram a estimativa da transmissão e absorção de luz pelas árvores e sua disponibilidade ao cafeeiro.

O fluxo de seiva dos cafeeiros foi estimado pelo método de balanço de calor por meio de sensores construídos pela Dynamax Inc., instalados no tronco dos cafeeiros (sensores modelos SGA 10 e SGB 25) e ligados a um sistema de aquisição de dados, modelo CR10X - Campbell Scientific Inc. no período de 6 a 11-dez-2002 e de 16 a 25-fev-2003. Os sensores foram instalados nas distâncias -5,7; 1,5; 4,9; $11,7 \mathrm{~m}$ e em monocultivo $(50 \mathrm{~m})$. Foi avaliada uma planta por posição dada a limitação de equipamento, repetindo-se as medições nas diferentes épocas. Tal método baseia-se na aplicação de calor em um segmento de tronco medindo-se suas perdas por condução axial (para cima e para baixo) e radial (assume-se uma constante para o fluxo de energia que migra ao interior da planta em função de sua constituição) e a variação da energia térmica armazenada. $\mathrm{O}$ fluxo de seiva é portanto determinado pelo balanço dessas perdas e a potência aplicada, sendo técnica precisa e de boa resposta dinâmica (Marin, 2003; Angelocci, 2001). Este método é dos mais utilizados, por não necessitar de calibração (Angellocci e Valancogne, 1993). 


\section{3 Resultados e Discussão}

Como apresentado no trabalho anterior dessa série, (capítulo 8: Simulação e disponibilidade de luz e crescimento de cafeeiros em sistema agroflorestal com seringueiras), a fração da radiação disponível aumentou com o distanciamento das árvores podendo ser descrita pelo modelo matemático proposto por Goudriaan (1977). A adequação do uso deste modelo matemático na estimativa da radiação disponível às culturas intercalares foi confirmada por Pinto (2002), Righi (2000); Bernardes et al. (1998a $e$ b); Castro \& Bernardes (2000). Os últimos autores propuseram uma modificação em seu cálculo original chegando-se a uma melhor aproximação. Uma maior discussão a respeito das modificações nas estruturas de copa dos cafeeiros, e sua influência na captura de luz e crescimento, pode ser encontrada no capítulo anterior.

A disponibilidade relativa de luz nas distâncias das árvores avaliadas - a contar da borda (dentro) -5,7 m, (ao lado) 1,5; 4,9; 11,7 m e em monocultivo (50 m) foram respectivamente: $35 \%$; $45 \% ; 80 \%$; $95 \%$ e $100 \%$.

Apesar de haver uma defasagem temporal entre a transpiração e a reposição hídrica indicada pelo fluxo de seiva, como todos os cafeeiros foram irrigados e o solo mantido próximo à sua capacidade de campo, assumiu-se que o total de fluxo de seiva observado foi equivalente ao total transpirado no dia. O fluxo de seiva estimado apresentou um padrão de variação semelhante em todas as posições avaliadas durante um mesmo dia, porém o total escoado diferiu grandemente entre as posições e entre os dias para uma mesma posição (Figura 2a).

Ao contrário do esperado, os cafeeiros a pleno sol, mesmo possuindo maior área foliar total e encontrando-se sob condições micrometeorológicas mais adversas (excesso de radiação, ventos, etc.), apresentaram fluxo de seiva relativamente baixo durante o período avaliado, quando comparado aos cafeeiros mais protegidos pelas árvores (Figura 2a). Há ainda grandes variações inerentes de cada planta individual que praticamente impediriam sua comparação direta. Tal fato, certamente levaria a falsas conclusões pois é necessária sua redução a valores comparáveis, como sua divisão pela área foliar de cada planta, ocasionando mudanças significativas na interpretação dos dados (Figura $2 b$ ). Assim, quando a transpiração é dividida pela 
área foliar, pode-se observar mudanças na disposição relativa dos fluxos de seiva de cada posição.

Vale ressaltar que em nenhum momento do dia, mesmo durante o auge do verão no hemisfério sul (22/dezembro - solstício de verão), o fluxo de seiva dos cafeeiros cessou. Ao contrário, o auge do escoamento deu-se ao redor do meio-dia (Figuras $2 a$ e $b$ ). Tal fato está de acordo com os reportados por Carelli et al (2000) que observaram um aumento na densidade de fluxo de seiva dos cafeeiros com aumentos na irradiância. 

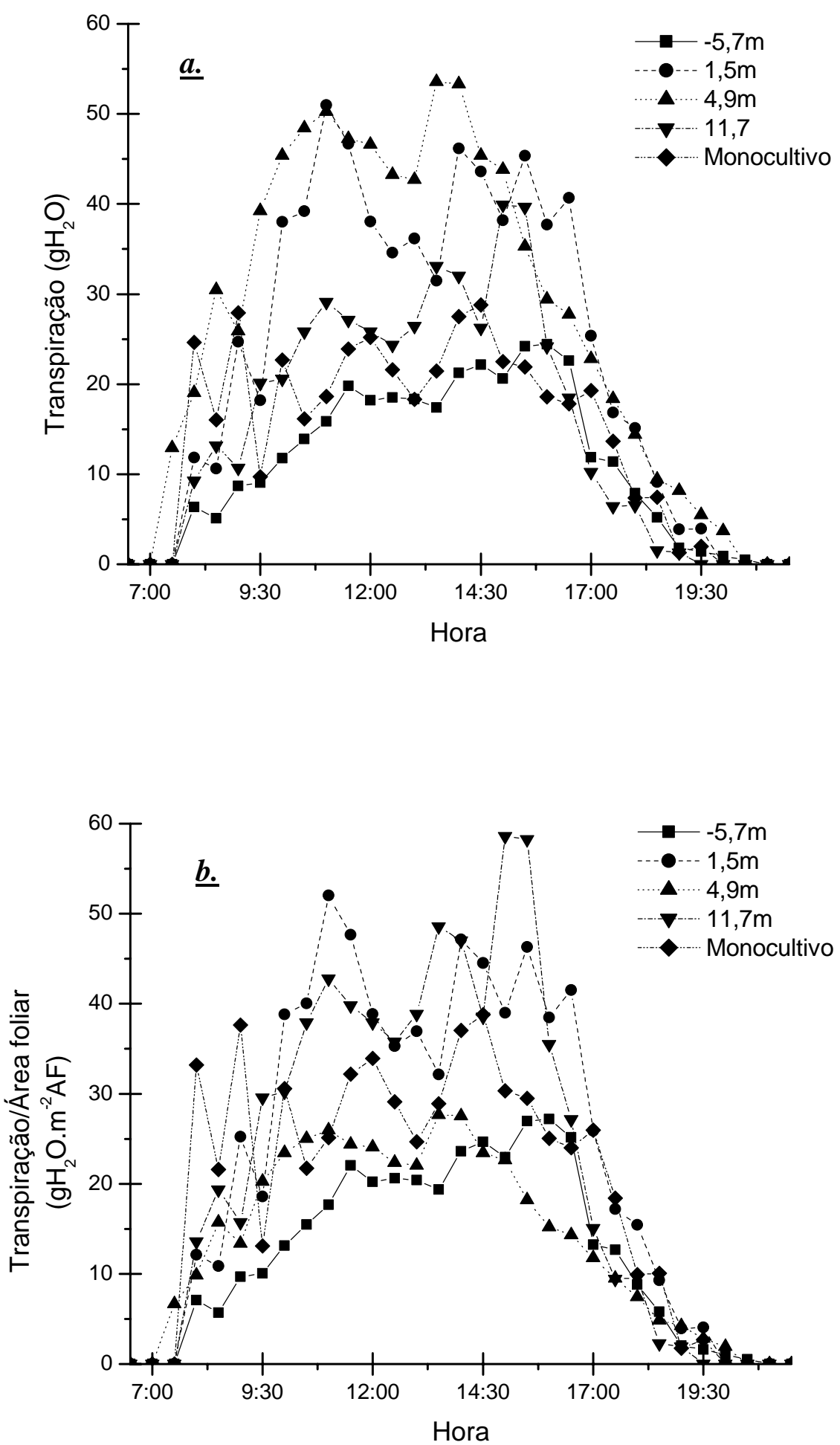

Figura $2 a$ - Fluxo de seiva dos cafeeiros $\left(\mathrm{gH}_{2} \mathrm{O}\right)$ nas distâncias avaliadas e; $\boldsymbol{b}$ - Fluxo de seiva dos cafeeiros por unidade de área foliar $\left(\mathrm{gH}_{2} \mathrm{O} \cdot \mathrm{m}^{-2}\right.$ Área foliar), em 06/dezembro/2002. Cada linha representa uma única planta em sua respectiva distância das árvores $(-5,7 ; 1,5 ; 4,9$; $11,7 \mathrm{~m}$ e em monocultivo) - ver legenda 
Como bem explanado por Givinish (1988) a respeito da adequação em expressar fotossíntese por unidade de massa foliar e dada sua estreita ligação com a perda de água, julgou-se conveniente e elucidativo também expressar a transpiração por unidade de massa foliar, abrangendo dessa forma seus custos energéticos por inferência.

A Figura 3 apresenta a transpiração dos cafeeiros nas diversas posições nos meses de dezembro/2002 e fevereiro/2003. Os valores de perda de água (fluxo de seiva $\left.-\mathrm{gH}_{2} \mathrm{O} \cdot \mathrm{dia}^{-1}\right)$ foram divididos pela área foliar total $\left(\mathrm{AFT}-\mathrm{m}^{2}\right)$ de cada planta (Figura $3 a$ e $b$ ), pela massa de folhas obtida por sua relação com a área foliar específica (AFE $\mathrm{m}^{2} \cdot \mathrm{kg}^{-1}$ ) (Figura $3 c$ e $d$ ) e, pela radiação incidente (MJ) mensurada pelo tubo solarímetro na referida posição (Figura $3 e$ e $f$ ).

Os valores de fluxo de seiva quando divididos por AFT $\left(\mathrm{m}^{2}\right)$ apresentaram um aumento gradativo com o distanciamento das árvores em direção ao monocultivo nos dois períodos avaliados (Figura $3 a$ e $b$ ), com uma leve inflexão ao redor de $10 \mathrm{~m}$ de distância. Em dezembro/2002, os menores valores foram obtidos a $-5,7 \mathrm{~m}$ de distância das árvores (interior do seringal), porém com grande acréscimo em fevereiro/2003, quando praticamente equiparou-se aos valores do monocultivo. Os valores observados $\left(\mathrm{gH}_{2} \mathrm{O} . \mathrm{m}^{-2}\right.$ Área foliar) foram em média: 288,99; 467,28; 319,69; 490,78; 421,93 em dez/2002 e 495,54; 590,71; 579,25; 559,99; 472,12 em fev/2003 para as distâncias $-5.7 ; 1.5 ; 4.9 ; 11.7$ m e em monocultivo, respectivamente. Assim, a transpiração total por planta foi maior nas condições mais iluminadas dada a sua maior AFT (ver Figura $5 a$ - seção 8.3). De outra maneira, a transpiração, quando dividida pela massa foliar ( $\mathrm{g}$ ) (Figura $3 c$ e $d$ ), apresentou tendência exatamente oposta, que foi melhor evidenciada no mês de fevereiro/2003 (Figura 3d).Os valores médios observados $\left(\mathrm{gH}_{2} \mathrm{O} . \mathrm{g}^{-1}\right.$ Massa foliar) foram: 4,53; 5,02;3,34;4,87; 3,87 em dez/2002 e 7,78; 6,34; 6,05; 5,56; 4,33 em fev/2003, para as mesmas distâncias. Pode-se observar o mesmo padrão de variação nos dois meses analisados, quando a transpiração por área foliar $\left(\mathrm{gH}_{2} \mathrm{O} \cdot \mathrm{m}^{-2}\right.$ Área foliar) foi reduzida pela radiação disponível (MJ) em cada uma das posições avaliadas. A nítida queda da transpiração $\left(\mathrm{gH}_{2} \mathrm{O} \cdot \mathrm{m}^{-2}\right.$ Área foliar.MJ $\left.{ }^{-1}\right)$ seguiu a forma de uma exponencial invertida em direção ao monocultivo (Figura $3 e$ e $f$ ), representado aqui pela distância de $50 \mathrm{~m}$. Os cafeeiros sob efeito da sombra apresentaram a maior perda de água por unidade de 
irradiação incidente. De outra maneira, as plantas em monocultivo (pleno sol) apresentaram a menor perda de água quando expressada pela mesma unidade. Para as posições avaliadas, o uso médio foi de: 64,$71 ; 67,75 ; 25,89 ; 33,54 ; 27,11 \mathrm{gH}_{2} \mathrm{O}^{-}$ ${ }^{2}$ Área foliar. $\mathrm{MJ}^{-1}$ em dezembro/2002 e de 97,14; 72,50; 40,70; 32,78; 26,13 $\mathrm{gH}_{2} \mathrm{O} . \mathrm{m}^{-}$ ${ }^{2}$ Área foliar. $\mathrm{MJ}^{-1}$ em fevereiro/2003. A repetição dos padrões de variação durante os dias avaliados e nos dois diferentes meses leva a crer na constância destas tendências. A transpiração por energia disponível $\left(\mathrm{gH}_{2} \mathrm{O} \cdot \mathrm{MJ}^{-1}\right)$ e a transpiração por energia por área de projeção da copa $\left(\mathrm{gH}_{2} \mathrm{O} \cdot \mathrm{m}^{-2}\right.$ Área projeção copa. $\left.\mathrm{MJ}^{-1}\right)$, como proposto por Villa Nova ${ }^{6}$, apresentaram a mesma tendência de diminuição da transpiração em direção ao monocultivo.

As variáveis $\mathrm{gH}_{2} \mathrm{O} . \mathrm{m}^{-2}$ Área foliar. $\mathrm{MJ}^{-1}$ e $\mathrm{gH}_{2} \mathrm{O} . \mathrm{g}^{-1}$ Massa foliar apresentaram correlações altamente significativas para o teste $\mathrm{F}$ com a distância das árvores. De outro modo a variável $\mathrm{gH}_{2} \mathrm{O} \cdot \mathrm{m}^{-2}$ Área foliar ${ }^{-1}$ não apresentou significância para o mesmo teste (Tabela 1 - Anexo). Ainda na mesma tabela, todas as variáveis apresentaram alta significância para o teste $\mathrm{F}$ quando analisadas independentemente.

Apesar da menor transpiração total dos cafeeiros sob intenso sombreamento $(-5,7 \mathrm{~m})$, as plantas apresentaram os maiores valores de transpiração por massa foliar $\left(\mathrm{gH}_{2} \mathrm{O} \cdot \mathrm{g}^{-1}\right.$ Mass foliar). Tais fatos são explicados por apresentarem a menor AFT e a maior área foliar específica $\left(\mathrm{AFE}-\mathrm{m}^{2} \cdot \mathrm{kg}^{-1} 15,71 ; 10,75 ; 10,45 ; 9,93 ; 9,17\right.$ para as distâncias $-5,7 ; 1,5 ; 4,9 ; 11,7 \mathrm{~m}$ e em monocultivo, respectivamente), o que significa folhas mais finas e de maior tamanho. Mudança nos valores da AFE é uma importante característica das plantas, comumente encontrada em espécies que apresentam adaptação às diferentes condições de luminosidade, que foi reportada por diversos autores (Pereira, 2002; Righi, 2000; Fahl, 1989; Esau, 1977).

As modificações morfológicas nas plantas, decorrentes de sua exposição aos diferentes regimes de radiação, implicam em mudanças drásticas de suas relações com o ambiente. Além das modificações na estrutura foliar (expressa pelo AFE), os cafeeiros avaliados apresentaram grandes alterações em sua arquitetura de copa arredondamento, abertura, projeção e volume - bem como no número de folhas, na densidade foliar e no índice de área foliar. Tais variações são apresentadas e

\footnotetext{
${ }^{6}$ Villa Nova, N.A. - Comunicação pessoal, 2005
} 
discutidas no capítulo anterior dessa tese, (capítulo 8 - Simulação e disponibilidade de luz e crescimento de cafeeiros em sistema agroflorestal com seringueiras).

$\mathrm{O}$ entendimento das complexas interações existentes entre plantas e ambiente, como um todo, necessita apoiar-se em resultados obtidos por diversos autores nas mais diferentes escalas de abordagem do problema. Assim parece que, ao juntar-se as várias evidências já encontradas, pode-se melhor compreender a realidade dos fatos observados.

A filotaxia, arranjo das folhas, de espécies adaptadas a condições de sombra é geralmente organizada em uma série planar com ramos próximos à horizontal ("distichous phylotaxis" dos ramos plagiotrópicos) (Hallé et al., 1978; Leigh, 1975). Este é o padrão da disposição foliar do cafeeiro. Segundo Givinish (1984), tal arquitetura de copa por apresentar folhas com pouca sobreposição, o aumento dos custos transpiracionais devido à exposição direta à radiação em ambientes de baixa luminosidade seriam praticamente nulos. Assim, o baixo auto-sombreamento teria um grande impacto no balanço de carbono, principalmente em ambientes com irradiância próxima ao ponto de compensação.

Jarvis \& Slatyer (1966) sugeriram que as resistências nos espaços inter celulares $\left(\mathrm{r}_{\mathrm{i}}\right)$ podem ser um componente significativo da resistência estomática $\left(\mathrm{r}_{\mathrm{s}}\right)$ quando os estômatos estão abertos. Pode-se esperar que $r_{i}$ seja maior em folhas mais grossas do que em finas e maior em folhas com pequenos espaços intercelulares do que em folhas com maiores espaços. Um aumento na taxa fotossintética por unidade de área foliar tenderia a aumentar a eficiência do uso da água (EUA). Um aumento na razão superfície de células do mesófilo/superfície foliar certamente levaria a aumentos na EUA por aumentar a fotossíntese mais do que a transpiração (Nobel, 1980).

Nutman (1937b) foi o primeiro a documentar o fechamento estomático do cafeeiro a pleno sol ao meio dia como sendo consistentemente dependente da intensidade de radiação sob variáveis condições climáticas. Vários autores encontraram maiores valores de abertura estomática em cafeeiros sob proteção ou auto-sombreamento e em dias nublados ou chuvosos. (Fanjul et al., 1985; Kumar \& Tieszen, 1980b; Maestri \& Vieira, 1958; Franco, 1938; Nutman, 1937b). 
Givinish (1984) aponta que o auto-sombreamento, devido à sobreposição de folhas, diminuiria a carga calorífica e os custos de transpiração em ambientes altamente iluminados. Dessa forma, o aumento da densidade foliar nos cafeeiros a pleno sol, em relação aos mais sombreados, parece atuar como um mecanismo de defesa a altas temperaturas, pois os cafeeiros adaptam-se melhor a ambientes com temperaturas do ar variando entre 18 e $22{ }^{\circ} \mathrm{C}$. Nunes (1988) encontrou que a temperatura e o déficit de pressão de vapor, e não a irradiância, são os fatores mais importantes na regulação estomática, uma vez que a irradiância esteja acima de um valor crítico. Foi provado por Ludlow \& Powles (1988) que o sombreamento pode elevar o status hídrico e diminuir a temperatura das folhas em plantas sob estresse hídrico.

Sampaio (2003), em experimento similar ao aqui apresentado com plantas de açaí (Eutherpe oleracea) em SAF com seringueira, encontrou que a diferença de temperatura do ar em relação ao monocultivo não foi maior que $1{ }^{\circ} \mathrm{C}$ mesmo nas horas mais quentes do dia. Por conseguinte, mudanças no déficit de pressão de vapor pouco diferiram nos dois ambientes.

Meinzer et al. (1990) observaram que a maior EUA foi resultado da redução da abertura estomática ao invés de aumentos na fotossíntese, uma vez que esta estaria linearmente correlacionada com a primeira.

Frente aos resultados obtidos, corroborados pelas evidências encontradas pelos diversos autores acima discutidos, pode-se inferir que os cafeeiros próximos às árvores (sob o efeito da sombra), de forma geral possuíam folhas maiores e delgadas, estômatos mais abertos devido aos maiores potenciais hídricos. No entanto, as plantas apresentaram menor acúmulo de matéria seca devido à acentuada redução na disponibilidade de luz. De outro modo, os cafeeiros em monocultivo (pleno sol) comportaram-se de maneira exatamente oposta, apresentando folhas menores e mais grossas, estômatos com redução em sua abertura devido aos menores potenciais hídricos, e maior acúmulo de matéria seca. Assim, os resultados obtidos pela divisão da transpiração pela massa foliar (Figuras $3 c$ e $d$ ), claramente mostram tais fatores atuando no sistema, de modo que a transpiração decaísse com o distanciamento das árvores. 
Parece não haver mais dúvidas da correlação direta entre a fração da irradiância disponível e a fração de matéria seca acumulada (fotossíntese líquida) até o ponto de saturação como observado e comentado por vários autores para diversas culturas (Pinto, 2002; Righi, 2000; Bernardes et al., 1998b; Ong et al. 1996; Russell et al., 1989). Como a transpiração por massa foliar e a transpiração por área e energia deram-se de modo oposto ao acúmulo de matéria seca, tais evidências parecem confirmar a maior EUA nas plantas a pleno sol. Nas plantas mais sombreadas, os estômatos aparentemente pouco atuaram de modo a restringir a perda de água, dado o ambiente mais ameno em que se encontravam, apresentando portanto a menor EUA. As Figuras $3 e$ e $3 f$, ao incluírem dados da radiação disponível, são elucidativas na confirmação desta tendência. 

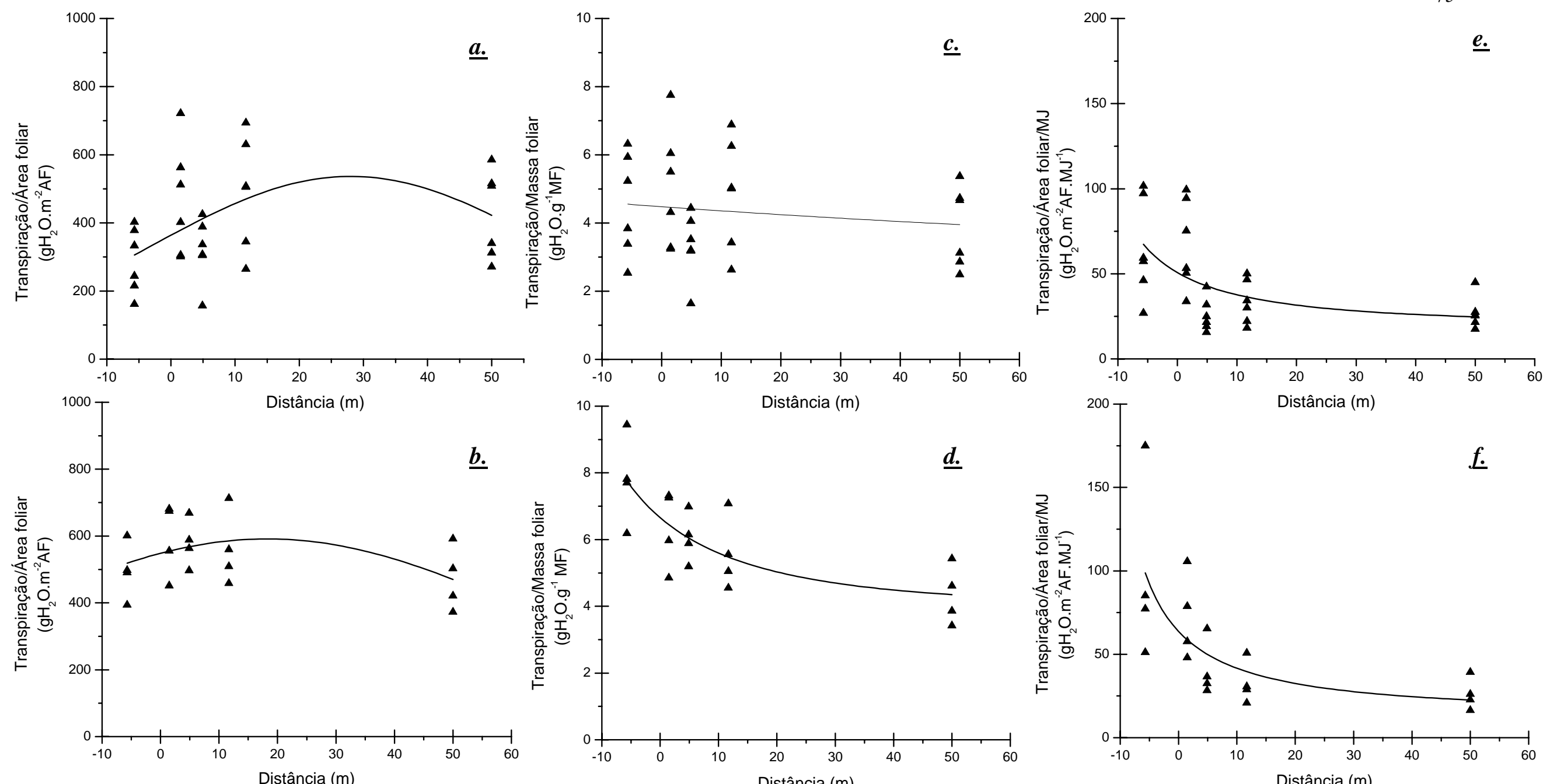

- Transpiracão dos cafeeiros por área foliar ( $\mathrm{gH}_{2} \mathrm{O} \cdot \mathrm{m}^{-2}$ Area foliar) nos períodos de 6-11/dez/2002 e 16-25/fev/2003 respectivamente para as distâncias de: $-5,7 ; 1,5 ; 4,9 ; 11,7 \mathrm{~m}$ a contar da borda do seringal e em monocultivo $(50 \mathrm{~m})$. $\underline{c \text { e d }}$ - Transpiração dos cafeeiros por massa foliar

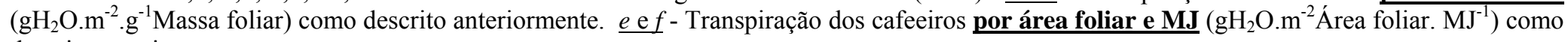
descrito anteriormente 


\section{4 Conclusões}

A transpiração por área foliar dos cafeeiros diminuiu com o sombreamento, o que é vantajoso na conservação da água no solo. Entretanto, o sombreamento elevou a perda de água por unidade de área foliar e energia incidente, o que indica uma possível menor EUA. De outro modo, plantas em monocultivo (pleno sol) apresentaram a menor perda de água por unidade de área foliar e energia incidente.

\section{4. 1 Considerações Finais}

A evolução das plantas e sua colonização das terras firmes somente foram possíveis pelo desenvolvimento dos estômatos, um eficiente sistema controlador da perda de água.

Este estudo permitiu averiguar sobre a propriedade de mensurar a transpiração das plantas com base em sua massa foliar (utilizando-se o AFE) podendo ser uma maneira de acessar sua adaptação aos diversos ambientes, o que fica inacessível quando expressa por base de área foliar.

Como apontado por Kramer (1983), os objetivos do manejo de culturas devem ser o de minimizar a perda de água por evaporação do solo e a máxima utilização pela cultura. A cobertura do solo pela copa das plantas em muito reduziria a perda de água por evaporação. Novos estudos são necessários no sentido de entender-se até que ponto as condições micrometeorológicas menos favoráveis a evaporação teriam importância na preservação da água no solo. Neste sentido, seria importante a quantificação das perdas de água por transpiração e por evaporação separadamente, ao invés dos costumeiros estudos de evapotranspiração. 


\section{PROBLEMAS NA UTILIZAÇÃO DO MÉTODO DE BALANÇO DE CALOR NAS DETERMINAÇÕES DE FLUXO DE SEIVA EM SERINGUEIRAS (Hevea brasiliensis Müell. Arg.) E CAFEEIROS (Coffea arabica L.)}

\section{Resumo}

As medições da transpiração de plantas são importantes na compreensão dos mecanismos e interações existentes no sistema solo-planta-atmosfera. Poucos são os estudos de fluxo de seiva em plantas tropicas utilizando métodos, como os térmicos, que permitam sua avaliação em campo e sob condições diversas. $\mathrm{O}$ emprego do método de balanço de calor em seringueiras e cafeeiros vem apresentando problemas como injúrias e a morte generalizada das plantas avaliadas. Outros métodos podem ser empregados e necessitam ser testados, como o de Granier, de baixo custo de fabricação e de fácil utilização.

Palavras-chave: seringueira, cafeeiro, transpiração, fluxo de seiva, balanço de calor

PROBLEMS WITH THE USE OF HEAT BALANCE METHOD IN DETERMINING THE SAP FLOW OF RUBBER TREES (Hevea brasiliensis Müell. Arg.) AND COFFEE PLANTS (Coffea arabica L.)

\section{Summary}

Plant transpiration measurements are very important in understanding the soil-plantatmosphere interactions. Only a few studies involving sap flow measurements have been done in tropical plants using methodologies that allow its field evaluation under diverse 
conditions such as the thermic methods. The use of the heat balance method in rubber trees and coffee plants has shown problems resulting to injury and even death of evaluated plants. Other low cost and easily operated methods, such as the Granier, could be used and should be tested.

Key-words: rubber trees, coffee, transpiration, sap flow, heat balance

\section{1 Introdução}

A medida da transpiração constitui-se em um elemento essencial na compreensão da fisiologia das árvores e de sua dinâmica na transferência de água em comunidades florestais (Granier, 1985). Além disso, desempenha importante papel no balanço energético da planta com o meio e na absorção de dióxido de carbono para a fotossíntese (Angelocci, 2002).

A determinação do fluxo de seiva no xilema tem merecido grande atenção, principalmente em árvores, pois sua medição em campo é sempre difícil. Alguns métodos utilizam marcadores radioativos ou corantes, outros são baseados no fornecimento de calor e sua dissipação. Dentre estes últimos, podemos utilizar uma das três técnicas já empregadas com sucesso na determinação dos fluxos de seiva: (1) Método do Pulso de Calor - medição da velocidade de dissipação de um pulso de calor fornecido ao caule ou ramo transportador de seiva (Huber, 1932; Huber \& Schmidt, 1937); (2) Método do Balanço de Calor - balanceamento do calor dissipado em um certo volume de caule ou ramo através do fluxo contínuo e constante de calor (Sakuratani, 1981; Valancogne \& Nasr, 1989; Weibel \& Vos, 1994) e; (3) Método da Sonda de Calor ou Método de Granier - medição da dissipação do calor aplicado internamente ao tronco por meio de sondas (Granier, 1985; 1987).

\section{2 Material e Métodos}

Com a finalidade de verificar e comparar os fluxos de seiva de árvores adultas de seringueiras (Hevea spp. - cultivar PB 235) com 12 anos de idade, e de cafeeiros (Coffea arabica L. cv. Obatã, IAC - 1669-20) de um ano e meio de idade, sob diferentes 
condições de cultivo, foi realizado um experimento em Piracicaba - SP $\left(22^{\circ} 42^{\prime} 30^{\prime \prime}\right.$ S, 47 $38^{\prime} 00^{\prime \prime}$ O) na Escola Superior de Agricultura "Luiz de Queiroz" - ESALQ/USP. As seringueiras nunca haviam sido sangradas. Neste experimento foi empregado o método de balanço de calor na estimativa dos fluxos de seiva. O método baseia-se na aplicação de calor em um segmento de tronco, medindo-se suas perdas por condução axial (para cima e para baixo) e radial (assume-se uma constante para o fluxo de energia que migra ao interior da planta em função de sua constituição) e a variação da energia térmica armazenada. O fluxo de seiva é portanto determinado pelo balanceamento dessas perdas e a potência aplicada (Marin, 2002). Esse talvez seja o método mais utilizado, possivelmente por não necessitar de calibração (Angellocci \& Valancogne, 1993). No Brasil, tal método foi utilizado com sucesso por Trejo-Chadia, (1997); Marin et al. (2002) e Coelho Filho (2002) em tomateiro, limoeiro e plantas de milho. Não há registros na literatura de sua utilização em seringueiras.

Os sensores de fluxo de seiva modelo SGA 150 - WS (Dynamax Inc., Houston, TX) foram construídos sob encomenda do Departamento de Produção Vegetal da Escola Superior de Agricultura "Luiz de Queiroz", de modo que ocorresse um ajuste destes com os troncos das seringueiras o mais próximo do ideal. Para os cafeeiros utilizou-se os sensores modelos SGA 10 e SGB 25. Os dados obtidos foram registrados em um sistema de aquisição de dados modelo CR10X (Campbell Scientific Ltd.). Em ambas as culturas, após a determinação da seção de tronco a ser utilizada, procedeu-se à raspagem leve e superficial destes com o emprego de uma lixa de textura fina para uniformizar a área. De acordo com as instruções contidas no Manual de Instalação e Operação do fabricante, aplicou-se uma fina camada de pasta condutora de calor (eletrical insulating compound - G4 Dow Corning Corporation, Midland, MI) a base de silicone tanto no tronco como no interior do sensor com a finalidade de aumentar a superfície de contato. Procedeu-se a instalação do sensor, que teve suas extremidades vedadas para evitar a entrada de água e sua cobertura com estrutura refletiva própria. Os sensores permaneceram ligados às plantas, no máximo por 10 dias, sendo imediatamente retirados. $\mathrm{O}$ intervalo entre as sucessivas medições foi no mínimo de um mês. 


\section{3 Discussão}

Logo após a primeira medição, as árvores de seringueira apresentaram intensa exudação de látex com escorrimento pelo tronco na área onde os sensores foram instalados. Também ocorreu destacamento de sua casca em vários pontos formando protuberâncias de tamanhos variáveis (Figura $1 a$ e $b$ ). Ao retirar-se essa camada superficial observou-se o lenho já sendo atacado por fungos oportunistas. Ocorreram desprendimento da casca e de fungos oportunistas (Figura 2) e brotações generalizadas abaixo da linha de instalação dos sensores, indicando claramente um efeito de anelamento do tronco (Figuras $3 a$ e $b$ ). Mesmo diminuindo-se o tempo de amostragem para 3 a 5 dias, com os sensores ligados na mínima voltagem permitida pelo fabricante, as novas árvores avaliadas também apresentaram os mesmos sintomas.

Durante uma chuva mediana, após cerca de 10 meses da realização das primeiras medidas, uma das seringueiras avaliadas teve seu tronco partido horizontalmente na exata posição de instalação dos referidos sensores. Pôde-se observar uma pequena área, com cerca de $1 / 4$ do perímetro do tronco ainda ativa no transporte de seiva. Note-se que todas as árvores ainda estavam vivas e enfolhadas.

Todos os cafeeiros avaliados morreram, excetuando-se os que permaneceram com os instrumentos ligados por apenas 3 dias consecutivos. Após poucos dias das medições, as plantas apresentaram amarelecimento generalizado de suas folhas e terminaram secando por completo em menos de 15 dias.

Wiltshire et al. (1995) também observou o anelamento, brotações generalizadas e a morte de plantas (Fraxinus excelsior) atribuindo tal efeito à pasta condutora de calor que aparentemente limitou a respiração do cambio. Há ainda dúvidas, se os danos às plantas devem-se ao calor gerado pelos sensores, ao uso da pasta ou a ambos.

O fluxo de seiva em árvores de grande porte é ainda muito pouco estudado e mensurado através do uso de sensores desse tipo, dado ao seu elevado custo e mão de obra, e por apresentar inconvenientes quanto ao limitado tempo que pode permanecer no campo, dificuldades de ajuste aos troncos e problemas em seu isolamento térmico. Há portanto carência de maiores informações e resultados práticos. 
Outros métodos de determinação podem ser utilizados e precisam ser testados sob diversas condições. O Método de Granier (Granier, 1985; 1987) foi testado pelos autores neste mesmo experimento em substituição ao método anteriormente citado. Dentre as principais vantagens desse método podemos salientar: (1) pode permanecer nas plantas avaliadas por tempo prolongado, (2) demanda pouca mão-de-obra, (3) pode ser construído facilmente com o uso de agulhas de injeção e termopares, (4) baixíssimos custo de fabricação e, (5) necessita de apenas um canal no sistema de aquisição de dados. 


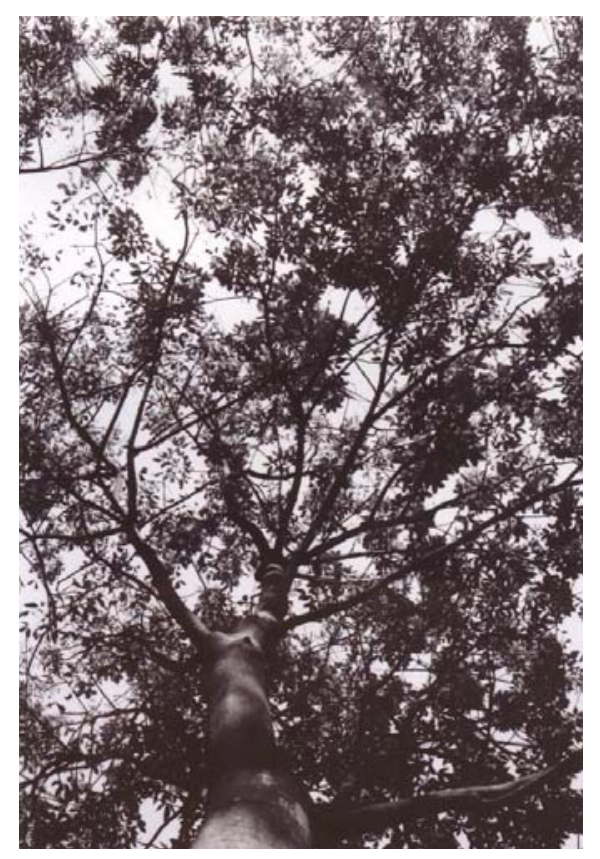

$a$

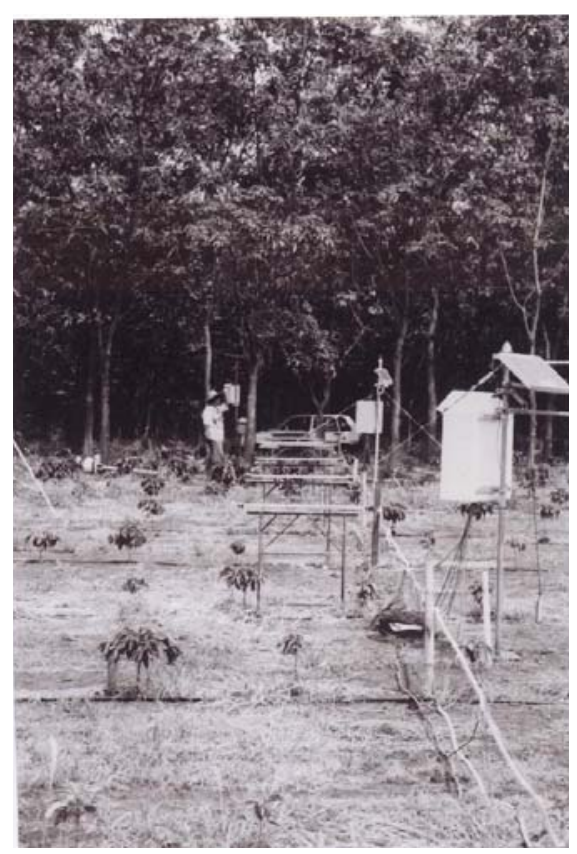

$a$

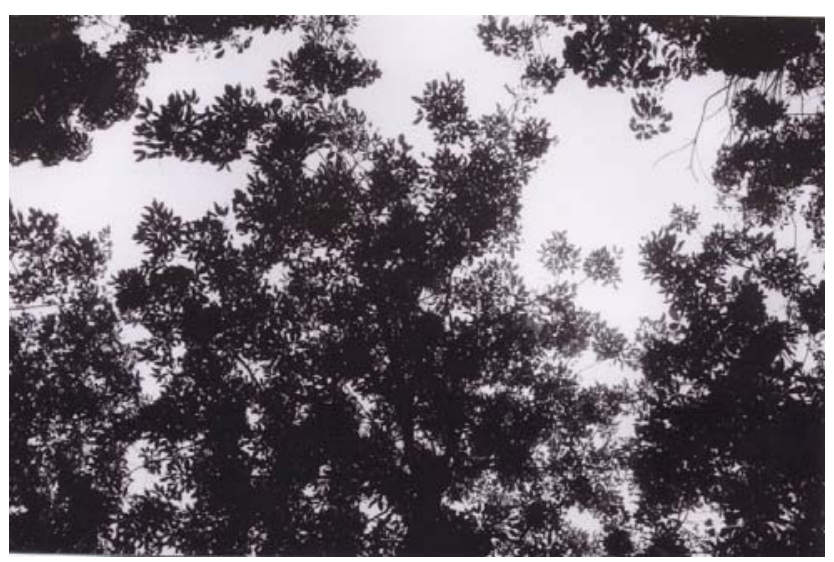

Figura $7 \boldsymbol{a}$ e $b$ - Visualização do dossel formado pelas seringueiras e do tipo de cobertura do solo proporcionado aos cafeeiros. Pode-se observar o agrupamento de folhas em pequenos tufos espalhados nas pontas dos ramos característicos de seu desenvolvimento.

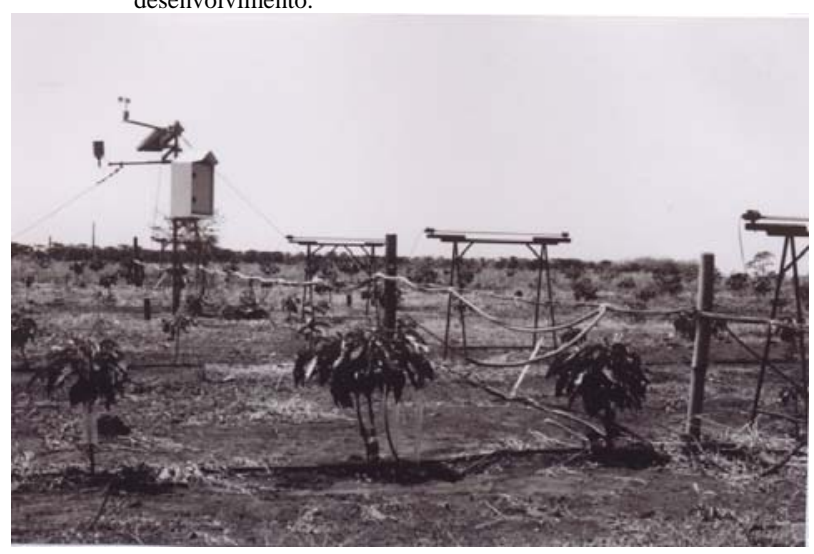

Figura $8 \boldsymbol{Q}$ e $b$ - Vista da disposição dos tubos solarímetros (TS-UM-3, Eijkelkamp) e da estação micrometeorológica (Delta-T Devices Inc.) no campo experimental - Piracicaba-SP.

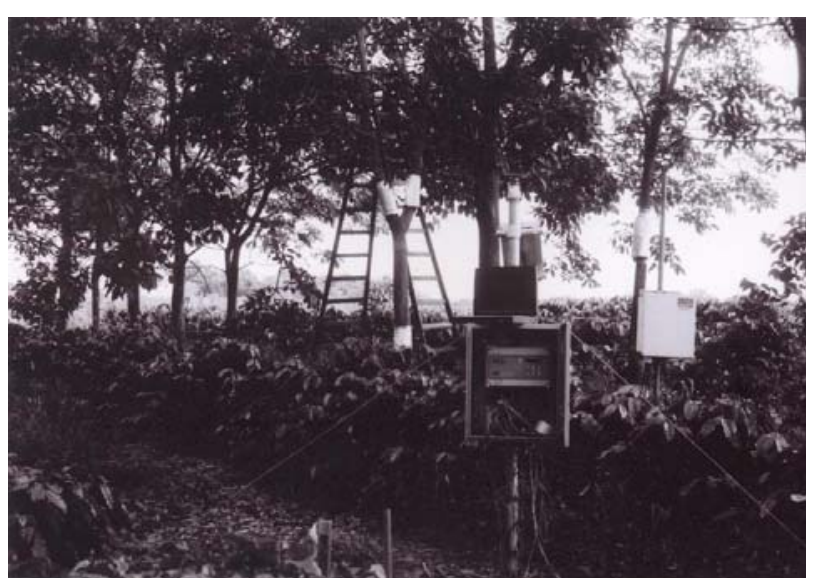

Figura 9 - Vista parcial do interior do seringal onde podemos observar as árvores com os sensores de fluxos de seiva do Método de Granier e o data-logger (Delta-T Devices Inc.) utilizado na coleta de seus dados. Observar árvore ao fundo com sensores tanto em seu tronco como nos dois ramos em que se subdivide para verificação de seu funcionamento. 


\section{CONCLUSÕES}

De acordo com os dados experimentais obtidos pôde-se concluir que:

(1) No intervalo entre 100 a $45 \%$ da irradiância disponível não houve redução no acúmulo de matéria seca dos cafeeiros. Maiores reduções da irradiância disponível levaram à diminuição do acúmulo de matéria seca diretamente proporcional, bem como modificações em suas características morfológicas e fisiológicas dada à adaptação a estas condições;

(2) O sombreamento teve um efeito positivo na redução da transpiração por unidade de área foliar e por planta. Por outro lado, teve um efeito negativo aumentando a transpiração por unidade de irradiância disponível;

(3) O modelo matemático proposto por Goudriaan (1977) e adaptado por Bernardes et al. (1998) simulou bem a disponibilidade de irradiância à cultura intercalar, com boa aproximação entre os valores medidos e estimados. Assim, sua disponibilidade está relacionada com a distância e tamanho das árvores sombreadoras. 


\section{1 Considerações finais e sugestões para futuros trabalhos}

O cafeeiro é tido como uma planta adaptada ao sombreamento e conseqüentemente ao cultivo consorciado por excelência. A origem da espécie dos subbosques dos altiplanos da região sul da Etiópia é bem conhecida (Krug, 1959; Kumar, 1979 e Evanoff, 1994), e tal situação é a referência para seu cultivo na maioria das regiões produtoras do mundo, exceção feita ao Brasil e ao Quênia, onde é cultivado comercialmente a pleno sol (da Matta et al. 1999).

As informações disponíveis sobre sombreamento mostram que há controvérsias quanto ao seu efeito e manejo. Tal polêmica, resulta que nas áreas de produção o sombreamento seja inadequadamente controlado. Sua utilidade recai na (i) redução da necessidade de adubação dada a diminuição da produtividade do cafeeiro, fator esse talvez necessário aos produtores mais carentes e, (ii) como uma ferramenta de marketing de confiabilidade duvidosa. Perde-se dessa forma, a oportunidade de otimização dos maiores benefícios potenciais da adoção dos SAFs, como por exemplo a conservação do solo, o aumento da infiltração de água e a opção de produção de outros produtos na mesma área.

Nesse experimento, constatou-se a capacidade do cafeeiro em adaptar-se a grandes reduções na disponibilidade de luz, dada principalmente por sua distância das árvores e conseqüente sombreamento, onde seu cultivo em SAF apresenta boa perspectiva. Tais adaptações são discutidas com detalhes no capítulo 8 e sumarizadas na tabela 1 (seção 8.3). Ao que tudo indica, existe um ponto de inflexão no desempenho do cafeeiro ao redor de $45 \%$ da disponibilidade lumínica, onde este apresenta abrupta mudança em vários aspectos fisiológicos e morfológicos. Dada a altura das árvores do presente experimento, ocorreu uma mudança abrupta das condições lumínicas aos cafeeiros, que a poucos metros de distância das árvores já se encontravam sob plena insolação. Sugere-se assim, que em futuros trabalhos utilize-se de árvores maiores, a fim de proporcionar uma maior gama de sombreamento ao redor de $45 \% \mathrm{I}_{0}$ e possibilitar um detalhamento de seu estudo. 
Ainda existem dúvidas quanto aos efeitos do sombreamento na cultura do cafeeiro e seus potenciais benefícios. Recomenda-se que futuras pesquisas nesta área, além de continuar os estudos com luz, por ser este o fator interveniente em todos os demais, devam principalmente:

1. verificar os efeitos da temperatura do ar e da folha no crescimento e produção do cafeeiro;

2. avaliar a qualidade da bebida do café em diversas condições ecológicas;

3. verificar quais tipos de árvores sombreadoras e seus manejos são mais adequados para atender as necessidades do produtor e da propriedade, além daquelas do cafeeiro;

4. verificar quais as razões fisiológicas que levam o cafeeiro a aparentemente saturar-se a $45 \%$ da radiação disponível;

5. separar transpiração da evaporação em estudos de SAF para verificar em que medida a evaporação do solo e a transpiração respondem de forma inversa e não proporcional às mudanças provocadas pelo sombreamento, com vistas a explicar a conservação da água e do ciclo hidrológico;

6. estudar o modo como as árvores podem interferir nas propriedades do solo;

7. ampliar o presente estudo com SAF sem o uso da irrigação;

8. fazer avaliação econômica dos sistemas de cultivo do cafeeiro sob tais variações. 
ANEXO 
Tabela 1 - Valores da probabilidade de F (Snedecor) em que foram analisadas as variáveis mensuradas no cafeeiro, sendo bloco a repetição de 1 a 4; tratamento as distâncias das árvores $(-13,7 ;-10,3 ;-5,7 ;-2,3$; 1,$5 ; 4,9 ; 8,3 ; 11,7 ; 15,1 ; 18,5 \mathrm{~m}$ e em monocultivo) ; C.V. ao coeficiente de variação; a probabilidade de $\mathrm{F}$ para as equações linear ou quadrática, bem como os parâmetros da primeira em que: $y=a+b x$

\begin{tabular}{lccccccc}
\hline \multicolumn{1}{c}{ Variável } & Bloco & $\begin{array}{c}\text { Tratamento } \\
\text { (Distância) }\end{array}$ & C.V. & Linear & Quadrátic & Parâmetros Equação \\
& & & & A & B \\
\hline Diâmetro Tronco & 0,0787 & 0,0275 & 4,4298 & 0,0001 & 0,0001 & 23,87 & 0,3175 \\
Diâmetro Copa a & 0,1559 & 0,9501 & 7,8489 & 0,0049 & 0,7161 & 93,21 & 0,3443 \\
Diâmetro Copa b & 0,1858 & 0,7763 & 7,8952 & 0,0086 & 0,9359 & 89,94 & 0,3015 \\
Altura Total & 0,5694 & 0,0480 & 7,1633 & 0,0835 & 0,8367 & 85,15 & $-0,1475$ \\
Altura Tronco & 0,3923 & 0,4441 & 5,5876 & 0,0005 & 0,5357 & 21,59 & $-0,07628$ \\
Número Folhas & 0,0190 & 0,7044 & 10,4402 & 0,0001 & 0,6357 & 289,36 & 9,3776 \\
Comprimento Folha & 0,0274 & 0,2201 & 4,4762 & 0,0001 & 0,0011 & 12,91 & $-0,1186$ \\
Largura Folha & 0,1559 & 0,1514 & 6,2023 & 0,0001 & 0,0025 & 6,44 & $-0,0649$ \\
Diâmetro Copa Médio & 0,1608 & 0,8912 & 7,6845 & 0,0056 & 0,8180 & 91,58 & 0,3229 \\
Altura Copa & 0,7004 & 0,0537 & 9,9824 & 0,3951 & 0,9357 & 63,56 & $-0,0712$ \\
Arredondamento Copa & 0,0615 & 0,0500 & 7,7452 & 0,0011 & 0,7275 & 1,47 & 0,0067 \\
Área Foliar & 0,7475 & 0,4077 & 15,3196 & 0,0001 & 0,3812 & 16132,00 & 269,79 \\
IAF & 0,3423 & 0,7385 & 15,7519 & 0,0070 & 0,7091 & 2,48 & 0,0176 \\
Porcentagem Copa & 0,8736 & 0,1001 & 3,2547 & 0,1327 & 0,9541 & 74,28 & 0,0506 \\
Abertura Copa & 0,0241 & 0,1397 & 6,3340 & 0,0001 & 0,8626 & 108,38 & 0,5924 \\
Projeção Copa & 0,8252 & 0,6641 & 6,8525 & 0,009 & 0,0003 & 3902,40 & $-43,6235$ \\
Volume Copa & 0,5881 & 0,4057 & 22,5290 & 0,0773 & 0,8981 & 770,28 & 2,5626 \\
Densidade Foliar & 0,5339 & 0,8645 & 20,8015 & 0,0208 & 0,6623 & 0,12 & 0,0009 \\
\hline
\end{tabular}

Tabela 2 - Valores da probabilidade de F (Snedecor) em que foi analisada a transpiração mensurada no cafeeiro, sendo área foliar - $\mathrm{AF}$; mega joule (MJ); massa foliar (MF); dia a repetição no tempo; tratamento as distâncias das árvores $(-5,7 ; 1,5 ; 4,9 ; 11,7 \mathrm{~m} \mathrm{e} \mathrm{em} \mathrm{monocultivo)} \mathrm{;} \mathrm{C.V.} \mathrm{ao}$ coeficiente de variação; a probabilidade de $\mathrm{F}$ para as equações linear ou quadrática, bem como os parâmetros da primeira em que: $y=a+b x$

\begin{tabular}{lccccccc}
\hline \multicolumn{1}{c}{ Variável } & Dia & $\begin{array}{c}\text { Tratamento } \\
\text { (Distância) }\end{array}$ & C.V. & Linear & Quadrática & Parâmetros Equação \\
& & & & & & B \\
\hline $\mathrm{gH}_{2} \mathrm{O} \cdot \mathrm{AF}^{-1} \cdot \mathrm{MJ}^{-1}$ & 0,0001 & 0,0001 & 32,2835 & 0,0001 & 0,0001 & 0,0062 & $-0,00008$ \\
$\mathrm{gH}_{2} \mathrm{O} \cdot \mathrm{MF}^{-1}$ & 0,0001 & 0,0094 & 19,3466 & 0,0015 & 0,1992 & 5250,13 & $-25,2048$ \\
$\mathrm{gH}_{2} \mathrm{O} \cdot \mathrm{AF}^{-1}$ & 0,0001 & 0,0010 & 16,6423 & 0,4092 & 0,0010 & 0,0448 & 0,00005 \\
\hline
\end{tabular}




\section{REFERÊNCIAS BIBLIOGRÁFICAS}

ALVIM, P.T. Physiology of growth and flowering in coffee. Turrialba, v. 2, p. 57-62, 1960.

ALVIM, P.T. Cacau. In: ALVIM, P.T.; KOZLOWSKI, T.T. (Ed.). Ecophysiology of tropical crops. New York: Academic Press, 1977. p. 279-313.

ANDERSON, L.S.; SINCLAIR, F.L. Ecological interactions in agroforestry systems. Agroforestry Abstracts, v.6, n.2, p.57-91, 1993.

ANDRADE, F.H.; UHART, S.A.; CIRILO, A. Temperature affect radiation use efficiency in maize. Field Crops Research, v.32, p. 17-25, 1993.

ANGELOCCI, L.R. Métodos e técnicas de estudo das relações água-plantaatmosfera. Piracicaba: ESALQ, 2001. $1 \mathrm{v}$.

ANGELOCCI, L.R. Água na planta e trocas gasosas/energéticas com a atmosfera: introdução ao tratamento biofísico. Piracicaba: O autor, 2002. 272 p.

ANGELOCCI, L.R.; VALANCOGNE, C. Leaf area and water flux in apple trees. Journal of Horticultural Science, v. 68, n. 2, p. 299-307, 1993.

BAGGIO, A.J.; CARAMORI, P.H.; ANDROCIOLI FILHO, A.; MONTOYA, L. Productivity of southern Brazilian coffee plantations shaded by different stocking of Grevillea robusta. Agroforestry Systems, v. 37. n. 2, p. 111-120, 1997.

BAKER, D.N.; MEYER, R.E. Influence of stand geometry on light interception and net photosynthesis in cotton. Crop Science, v.6, p. 15-19, 1966.

BALDY, C.; STIGTER, C.J. Agrométéorologie des cultures multiples en regions chaudes. Paris: INRA, 1993. 246 p.

BAUMER, M. Agroforestry and desertification: the potential role of agroforestry in combating desertification and environmental degradation with special reference to Africa. Wageningen: Technical Centre for Agricultural and Rural Cooperation, 1990. $250 \mathrm{p}$.

BEER, J.; MUSCHLER, R.; KASS, D.; SOMARRIBA, E. Shade management in coffee and cacao plantations. Agroforestry Systems, v.38, p.139-164, 1998. 
BERNARDES, M.S. Fotossíntese no dossel das plantas cultivadas. In: CASTRO, P.R.C.: FERREIRA, S.O.; YAMADA, T. (Ed.). Ecofisiologia da produção agrícola. Piracicaba: PATAFOS, 1987. cap. 2, p.13-48.

BERNARDES, M.S. Efeito de métodos químicos de indução de copa no desenvolvimento da seringueira (Hevea brasiliensis Müell. Arg. cv. RRIM 600). Piracicaba. 1989. 192p. Dissertação (Mestrado) - Escola Superior de Agricultura "Luiz de Queiroz", Universidade de São Paulo.

BERNARDES, M.S. Simulation of agroforestry systems: the case of rubber tree associated with other crops. Wageningen, 1993. 63p. Thesis (Doctor) - Wageningen Agricultural University.

BERNARDES, M.S.; FANCELLI, A.L. Seringueira como uma possível cultura intercalar para os pomares de Citrus. In: SIMPÓSIO DA CULTURA DA SERINGUEIRA, 2., Piracicaba, 1987. Anais. Piracicaba: ESALQ, Depto de Agricultura, 1990. p.223-252.

BERNARDES, M.S.; CASTRO, P.R.C.; MARTINS, A.N. Formação da copa e resistência de árvores ao vento: modelo de seringueira. Piracicaba: FEALQ, 1996. $88 \mathrm{p}$.

BERNARDES, M.S.; FURIA, L.R.R.; TERAMOTO, E.R.; BERNARDO, K.T. Interações abaixo da superfície do solo em sistema agroflorestal de seringueira (Hevea brasiliensis) e milho (Zea mays). In: CONGRESSO BRASILEIRO EM SISTEMAS AGROFLORESTAIS, 2., Belém, 1998. Resumos expandidos. Belém: Embrapa CPATU, 1998a. p.14-16.

BERNARDES, M.S.; GOUDRIAAN, J.; CÂMARA, G.M.S.; DOURADO-NETO, D. Tree-crop interactions in agroforestry system of rubber with soybean and maize. In: CONGRESS OF THE EUROPEAN SOCIETY FOR AGRONOMY, 5., Nitra, 1998. Short communications. Nitra: ESA, 1998b. v.2, p.125-126.

BERNARDES, M.S.; LIMA, S.F.F; TERAMOTO, E R.; RIGHI, C.A.; BERNARDES, A.S. Recuperação de solo degradado com sistema agroflorestal no extremo sul da Bahia. In: REUNIÃO BRASILEIRA CIÊNCIA DO SOLO E DA ÁGUA, 13., Ilhéus, 2000. Anais. Ilhéus: SBCS, 2000. 1v.

BIERHUIZEN, J.F.; NUNES, M.A.; PLOEGMAN, C. Estudos sobre a produtividade do cafeeiro. I Efeito da luz, temperatura e concentração de $\mathrm{CO}_{2}$ na fotossíntese de Coffea arabica L. Estudos Agronômicos, v. 11/12, p. 15-25, 1971.

BJÖRKMAN, O.; BOARDMAN, N.K. ANDERSON, J.M.; THORNE, S.W.; GOODCHILD, D.J.; PYLIOTIS, N.A. Effect of light intensity during growth of Atriplex patula on the capacity of photosynthetic reactions, chloroplast components and structure. Carnigie Institute Yearbook, v.71, p. 115-135, 1972.

BLACK, C.; ONG, C. Utilization of light and water in tropical agriculture. Agricultural and Forest Meteorology, v.104, p.25-47, 2000 
BOARDMAN, N.K. Comparative photosynthesis of sun and shade plants. Annual Review of Plant Physiology, v.28, p. 355-377, 1977.

BOARDMAN, N.K.; BJÖRKMAN, O.; ANDERSON, J.M.; GOODCHILD, D.J.; THORNE, S.W. Photosynthetic adaptation of higher plants to light intensity: relationship between chloroplast structure, composition of the photosystems and photosynthetic rates. In: INTERNATIONAL CONGRESS ON PHOTOSYNTHESIS, 3., Amsterdam, 1975. Proceedings. p. 1809-1827.

BOS, J. van den; RABBINGE, R. Simulation of the fluctuations of the gray larch bud moth. Wageningen: Centre for Agricultural Publishing and Documentation, 1976. 83p.

BOYER, J.S. Plant productivity and environment. Science, v.218, p. 443-448, 1982.

BRENNER, A.J. Microclimatic modifications in agroforestry. In: ONG, C.K.; HUXLEY, P. (Ed.). Tree-crop interactions: a physiological approach. Wallingford: CAB International, 1996. cap. 5, p.159-188.

CAIXETA, G.Z.T. Gerenciamento da cafeicultura em época de crise. In: ZAMBOLIM, L. Tecnologias de produção de café com qualidade. Viçosa: UFV, Departamento de Fitopatologia, 2001. p.1-24.

CAMARGO, A.P. de. O clima do Estado de São Paulo e a Agricultura. O Agronômico, v.18, n.7/8, p. 1-19, 1966.

CAMARGO, A.P. de. O clima e a cafeicultura no Brasil. Informe Agropecuário, v.11, n.126, p.13-26, jun. 1985 .

CAMPBELL, G.S.; NORMAN, J.M. The description and measurement of plant canopy structure. In: RUSSEL, G.; MARSHALL, B.; JARVIS, P.G. (Ed.). Plant canopies: their growth, form and function. Cambridge: Cambridge University Press, 1989. p. 1-20.

CAMPOE, O.C.; RIGHI, C.A.; CHRISTOFFOLETI, P.J.; COSTA, J.D.; ENGEL, V.L.; BERNARDES, M.S. Avaliação da densidade populacional de plantas daninhas em um sistema agroflorestal de seringueira e cafeeiro. In: SIMPÓSIO DE INICIAÇÃO CIENTÍFICA DA UNIVERSIDADE DE SÃO PAULO, 11., Piracicaba, 2003. Agropecuária: resumos. São Paulo: USP, 2003a. p. 10, res. 1.16.

CAMPOE, O.C.; RIGHI, C.A.; FAVARIN, J.L.; COSTA, J.D.; ENGEL, V.L.; BERNARDES, M.S. Quantificação da infestação de bicho-mineiro em cafeeiros sob diferentes condições de cultivo. In: SIMPÓSIO DE INICIAÇÃO CIENTÍFICA DA UNIVERSIDADE DE SÃO PAULO, 11., Piracicaba, 2003. Agropecuária: resumos. São Paulo: USP, 2003b. p. 82, res. 1.160.

CANNEL, M.G.R. Crop physiological aspects of coffee bean yield. Kenya Coffee, v. 41, n.484, p. 245-253, 1976. 
CARELLI, M.L.C.; FAHL, J.I.; TRIVELIN, P.C.O.; QUEIROZ-VOLTAN, R.B. Carbon isotope discrimination and gas exchange in Coffea species grown under different irradiance regimes. Revista Brasileira de Fisiologia Vegetal, v. 11. n. 2, p. 63-68, 1999.

CARELLI, M.L.C.; FAHL, J.I.; PEZZOPANE, J.R.M.; ALFONSI, E.L.; MAGOSSI, R. Densidade de fluxo de seiva em plantas de café (Coffea arabica L.) em diferentes regimes de água e de irradiância. In: SIMPÓSIO DE PESQUISA DOS CAFÉS DO BRASIL, 1., Poços de Caldas, 2000. Resumos. Poços de Caldas: Embrapa, 2000. p. $42-45$.

CASTRO, D.S.; BERNARDES, M.S. Estudo das relações de luz em sistemas agroflorestais de seringueira. Piracicaba: ESALQ, 2000. 45 p. (Relatório de estudos).

CASWELL R.; KOENING, H.E.; RESH, J.A.; ROSS, Q.E. An introduction to systems science for ecologists. In: LEFFELAAR, P.A. Systems analysis simulation in ecology. Academic Press, 1972. v. 2, p. 3-80.

CHANG, J. Climate and agriculture: an ecological survey. Chicago: Aldine, 1968. $304 p$.

COELHO FILHO, M.A. Determinação da transpiração máxima em um pomar jovem de lima ácida 'Thaiti'(Citrus latifolia Tan.) e sua relação com a evapotranspiração de referência. Piracicaba, 2002. 91 p. Tese (Doutorado) - Escola Superior de Agricultura "Luiz de Queiroz", Universidade de São Paulo.

CONFALONE, A.E.; COSTA, L.C.; PEREIRA, C.R. Eficiencia de uso de la radiación en distintas fases fenológicas bajo estrés hídrico. Revista de la Facultad de Agronomía, v. 17, n. 1, p. 63-66, 1997.p.

CORLETT, J.E.; ONG, C.K.; BLACK, C.R. Microclimatic modifications in intercropping and alley cropping systems. In: REIFSNYDER, W.S.; DARNHOFER, T.O. (Ed.). Meteorology and agroforestry. Nairobi: ICRAF, 1987. p. 419-430.

COSTA, L.C.; CONFALONE, A.E.; PEREIRA, C.R. Effect of water stress on the efficiency of capture of water and radiation by soybean. Tropical Science, v. 39, p. 1-7, 1999.

CRAWFORD, M.C.; NOBLE, P.A.; HAINES, P.J. Shelterbelts and wheat production in north east Victoria. In: AUSTRALIAN AGRONOMY CONFERENCE, 9., Waga Waga, 1998. Proceedings. p. 685-686.

CRESTANA, S. Técnicas recentes de determinação de características do solo. In: REUNIÃO BRASILEIRA DE MANEJO E CONSERVAÇÃO DO SOLO E DA ÁGUA, 10., Florianópolis, 1994. Resumos. Florianópolis: SBCS, 1994. p. 86-97.

DA MATTA, F.M.; AMARAL, J.A.T.; RENA, A.B. Growth periodicity in trees of Coffea arabica L. in relation to nitrogen supply and nitrate reductase activity. Field Crops Research, v. 60, n. 3, p. 223-229, 1999. 
DE WIT, C.T. Philosophy and terminology. In: LEFFELLAR, P.A. (Ed.). On systems analysis and simulation of ecological processes. Wageningen: Kluwer Academic, 1993. p. 3-9 (Current Issues in Production Ecology).

DURIGAN, G. Quebra-vento de Grevillea robusta A. Cunn. Efeitos sobre a velocidade do vento, umidade do solo e produção de café. IPEF, v.36, p. 27-34, 1987.

EHLERINGER, J.; BJÖRKMAN, O. Quantum yields for $\mathrm{CO}_{2}$ uptake in $\mathrm{C}_{3}$ and $\mathrm{C}_{4}$ plants. Plant Physiology, v.59, p. 86-90, 1977.

EMPRESA BRASILEIRA DE PESQUISAS AGROPECUÁRIAS - EMBRAPA. Centro Nacional de Pesquisa de Solos (Rio de Janeiro - RJ) Sistema Brasileiro de Classificação de Solos - Brasília: Embrapa, Produção de Informação; Rio de Janeiro: Embrapa Solos, 1999. (xxvi) 412p.: il.

ESAU, K. Anatomy of seed plants. 2.ed. New York: John Wiley, 1977. 550 p.

EVANOFF, C.E.A. Biologia del cafe. Caracas: Ed. Universidade Central de Venezuela, 1994. $308 \mathrm{p}$.

EVANS, J.R.; CAEMMERER, S. VON; ADAMS III, W.W. Ecology of photosynthesis in sun and shade. Melbourne: CSIRO, 1988. 358p.

FAHL, J.J. Influência da irradiância e do nitrogênio na fotossíntese e crescimento de plantas jovens de café (Coffea arabica L.). Campinas, 1989. 84 p. Tese (Doutorado) - Instituto de Biologia, Universidade Estadual de Campinas.

FAHL, J.I.; CARELLI, M.L.C.; VEGA, J.; MAGALHÃES, A.C. Nitrogen and irradiance levels affecting net photosynthesis and growth of young coffee plants (Coffea arabica L.). Journal of Horticultural Science, v. 69, p. 161-169, 1994.

FANJUL, L.; ARREOLA-R., R.; MENDEZ-C., M.P. Stomatal responses to environmental variables in shade and sun grown coffee plants in Mexico. Experimental Agriculture, v. 21, p. 249, 1985.

FARQUHAR, G.D. Carbon assimilation in relation to transpiration and fluxes of ammonia. In: MARCELlE, R.; CLIJSTERS, H.; POUCKE, M. van (Ed.). Photosynthesis and plant development. The Hague: Dr. Junk, 1979. p. 321-328.

FIELD, C.; BERRY, J.A.; MOONEY, H.A. A portable system for measuring carbon dioxide and water vapor exchange of leaves. Plant Cell Environment, v.5, p. 179186, 1982.

FNP CONSULTORIA \& COMÉRCIO. Agrianual 2004: anuário da agricultura brasileira. São Paulo, 2004. 496 p.

FRANCO, C.M. Sobre a fisiologia dos estomas do cafeeiro Coffea arabica L. In: REUNIÃO SUL-AMERICANA DE BOTÂNICA, Campinas, 1., 1938. Anais. Campinas, 1938. v.3, p. 293.

FRANCO, C.M. Fotoperíodismo em cafeeiro (Coffea arabica L.) Revista do Instituto do Café, v.27, n. 164, p. 1556-1592, 1963. 
FUJISAKA, S. Sense and nonsense: contour hedgerows for soil erosion control. Agroforestry Forum, v.8, n.4, p.8-11, 1997.

GALLAGHER, J.N.; BISCOE, P.V. Radiation absorption, growth and yield of cereals. Journal of Agricultural Sciences, v.91, p. 47-60, 1978.

GATES, D. M. Heat transfer in plants. Scientific American, v.213, p. 76-84, 1965.

GILLESPIE, A.R.; JOSE, S.; MENGEL, D.B.; HOOVER, W.L.; POPE, P.E.; SEIFERT, J.R.; BIEHLE, D.J.; STALL, T.; BENJAMIN, T.J. Defining competition vectors in a temperate alley cropping system in the Midwestern USA. I. Production physiology. Agroforestry Systems, v.48, p.25-40, 2000.

GIVINISH, T.J. Leaf and canopy adaptations in tropical forests. In: MEDINA, E.; MOONEY, H.A.; VÁSQUEZ-YÁNES, C. (Ed.). Physiological ecology of plants of the wet tropics. The Hague: Dr. Junk,1984. p. 51-84.

GIVINISH, T.J. On the economy of plant form and function. Cambridge: Cambridge University Press, 1986. 680p.

GIVINISH, T.J. Adaptation to sun and shade: a whole-plant perspective. In: EVANS, J.R.; CAEMMERER, S. von; ADAMS III, W.W. (Ed.). Ecology of photosynthesis in sun and shade. Melbourne: CSIRO, 1988. p. 63-92.

GIVINISH, T.J.; VERMEIJ, G.J. Sizes and shapes of liane leaves. American Naturalist, v.100, p. 743-778, 1976.

GOLDTHORPE, C.C. A review of environmental issues in natural rubber production. Planter, v.72, n.840, p. 123-128, 131-139, 1996.

GOUDRIAAN, J. Crop micrometeorology: a simulation study. Wageningen: PUDOC, 1977. 249p. (Simulation Monographs)

GOVINDARAJAN, M.; RAO, M.R.; MATHUVA, M.; NAIR, P. Soil-water and roots dynamics under hedgerow intercropping in semiarid Kenya. Agronomy Journal, v. 88, p. 513-520, 1996.

GRANIER, A. Une nouvelle méthode pour la mesure du flux de sève brute dans le tronc des arbres. Annales des Sciences Forestières, v. 42, n. 2, p. 193-200, 1985.

GRANIER, A. Mesure du flux de séve brute dans le tronc du douglas par une nouvelle méthode thermique. Annales des Sciences Forestières, v. 44, n. 1, p. 1-14, 1987.

HALL, A.E.; SCHULZE, E.D. Stomatal response to environment and a possible interrelation between stomatal effects on transpiration and $\mathrm{CO}_{2}$ assimilation. Plant Cell Environment, v.3, p. 467-474, 1980.

HALlÉ, F.; OLDEMAN, R.A.A.; TOMLINSON, P.B. Tropical trees and forests. New York: Cambridge University Press, 1978. 1v.

HAZRA, C.R. Soil and climatological studies in relation to agroforestry research. In: NARP TRAINING PROGRAMME, 1., Jhanshi, 1990. Jhanshi: IGFRI, 1990. 1v. 
HOLMGREN, P. Leaf factors affecting light-saturated photosynthesis in ecotypes of Solidago virgaurea from exposed and shaded habitats. Physiologia Plantarum, v.21, p.676-698, 1968.

HOPKINS, W.G. Introduction to plant physiology. Nova York: John Willey, 1995. $464 \mathrm{p}$.

HORN, H.S. The adaptive geometry of trees. Princeton: Princeton University Press, 1971. 1v.

HOWARD, A. The origin of alkali land. Agricultural Journal, v. 20, p. 461-629, 1925.

HUBER, B. Beobachtung und messung pflanzlicher saftströme. Berlin. Deutsch Botanisch. Ges., v. 50, p. 89-109, 1932.

HUBER, B.; SCHMIDT, E. Eine kompensationsmethode sur thermoelecktrischen messung langsamer stafstrome. Berlin. Deutsch Botanisch Ges., v. 55, p. 514-529, 1937.

HUNTER, J.R.; ERICKSON, A.E. Relation of seed germination to soil moisture tension. Agronomy Journal, v. 44, n.3, p. 107-109, 1952.

HUXLEY, P. Tropical agroforestry. Oxford: Blackwell Science, 1999. 371p.

INTERNATIONAL CENTRE OF RESEARCH ON AGROFORESTRY. Annual report. Nairobi, $1989.30 \mathrm{p}$.

INTERNATIONAL COFFEE ORGANIZATION. www.ico.org (01 out. 2004).

JARVIS, P.G.; SLATYER, R.O. A controlled environment chamber for studies of gas exchange by such surface of a leaf. Melbourne: CSIRO, Div. Land Res., 1966. (Technical Paper, 29)

JHA, L.K. Advances in agroforestry. New Dehli: APH Pub., 1995. 669 p.

JONES, H.G. Plants and microclimate: a quantitative approach to environmental plant physiology. Cambridge: Cambridge University Press, 1994. 428p.

KANG, B.T. Alley cropping: past achievements and future directions. Agroforestry Systems, v. 23, p. 141-155, 1993.

KING, D. Tree dimensions: maximizing the rate of height growth in dense stands. Oecologia, v. 51, p. 351-356, 1981.

KRAMER, P.J. Water relations of plants. New York: Academic Press, 1983. 489p.

KRAMER, P.J.; BOYER, J.S. Water relations of plants and soils. London: Academic Press, 1995. 495p.

KRUG, C.A. World coffee survey. Roma: FAO, 1959. 292 p.

KUMAR, D. Investigation into some physiological aspects of high density plantings of coffee (Coffea arabica L.). Kenya Coffee, v. 43, n. 510, p. 263-272, 1978. 
KUMAR, D. Some aspects of the physiology of Coffea arabica L. A review. Kenya Coffee, v. 44, p. 9-47, 1979.

KUMAR, D.; TIESZEN, L.L. Photosynthesis in Coffee arabica L.: I. effects of light and temperature. Experimental Agriculture, v.16. n. 1, p. 13-19, 1980a.

KUMAR, D.; TIESZEN, L.L. Photosynthesis in Coffea arabica L.: II. effect of water stress. Experimental Agriculture, v.16, p. 21-27, 1980 b.

LARCHER, W. Physiological plant ecology. Berlin: Springer - Verlag, 1975. 252 p.

LEAL, A.C. Quebra-ventos arbóreos: aspectos fundamentais de uma técnica altamente promissora. Informe da Pesquisa, IAPAR, v.10, n.67, p. 27, jul. 1986.

LEFFELAAR, P.A. On systems analysis and simulation of ecological processes: with examples in CSMP and FORTRAN. The Hague: Kluwer Academic, 1993. 293 p. (Current Issues in Ecology, 6).

LEIGH, E.G. Structure and climate in tropical rain forests. Annual Review of Ecology and Systematics, v.6, p. 67-86, $1975 .$.

LEONG, W. Canopy modification and its effects on growth and yield of Hevea brasiliensis. Ghent, 1980. 283 p. Thesis (Ph. D.) - Faculty of Agricultural Sciences of Ghent.

LINACRE, E.T. A note on feature of leaf and air temperatures. Agricultural Meteorology, v.1, p.66-72, 1964.

LOOMIS, R.S.; CONNOR, D.J. Crop ecology: productivity and management in agricultural systems. Cambridge: Cambridge University Press, 1992. 538p.

LUDLOW, M.M.; POWLES, S.B. Effects of photoinhibition induced by water stress on growth and yield of grain sorghum. In: EVANS, J.R.; CAEMMERER, S. VON; ADAMS III, W.W. (Ed.). Ecology of photosynthesis in sun and shade. Melbourne: CSIRO, 1988. p. 179-194.

LUNZ, A.M.P.; RIGHI, C.A.; BERNARDES, M.S.; COSTA, J.D.; FAVARIN' J.L. Produção do cafeeiro (Coffea arabica L.) em sistema agroflorestal em aléia de seringueira (Hevea brasiliensis Müell. Arg.) e em monocultivo. In: CONGRESSO BRASILEIRO DE SISTEMAS AGROFLORESTAIS, 5., Curitiba, 2004. Colombo: EMBRAPA Floresta, 2004. p.476-478. (EMBRAPA Floresta. Documentos, 98).

MAESTRI, M.; VIEIRA, C. Movimento dos estômatos em café sob condições naturais. Revista Ceres, v.10, p. 324, 1958.

MALKIN, S.; FORK, D.C. Photosynthetic units of sun and shade plants. Plant Physiology, v.67, p. 580-583, 1981.

MANN, H.S.; MUTHANA, K.D. Arid zone forestry. Jodhpur: ICAR CAZRI, 1984. 1v. (Monograph, 23). 
MARIN, F.R. Evapotranspiração e transpiração máxima em cafezal adensado Piracicaba, 2003. 118 p. Tese (Doutorado) - Escola Superior de Agricultura "Luiz de Queiroz", Universidade de São Paulo.

MARIN, F.R.; ANGELOCCI, L.R.; PEREIRA, A.R.; SENTELHAS, P.C.; VILLA NOVA, N.A. Balanço de energia e consumo hídrico em pomar de lima ácida 'Thaiti'. Revista Brasileira de Agrometeorologia, v. 17, n. 2, p. 219-228, 2002.

MAZZAFERA, P.; CARVALHO, A. Produção e tolerância à seca de cafeeiros. Bragantia, v.46, n.2, p. 403-415, 1987.

MCDONALD, M.A.; STEVENS, P.A.; HEALEY, J.R.; DEVI PRASAD, P.V.. Maintenance of soil fertility on steep lands in the Blue Mountains of Jamaica: the role of contour hedgerows. Agroforestry Forum, v.8, n.4, p.21-25, 1997.

MEINZER, F.C.; GOLDSTEIN, G.; GRANTZ, D.A. Carbon isotope discrimination in coffee genotypes grown under limited water supply. Plant Physiology, v.92, p. 130, 1990.

MONSI, M.; SAEKI, T. Über den lichtfaktor in den planzen-gesell-schaften und seine bedeutung für die Stoffproduktion. Japanese Journal of Botany, v.14, p.22-52, 1953.

MONTEITH, J.L. Light distribution and photosynthesis in field crops. Annals of Botany, v. 29, n. 113, p. 17-37, 1965.

MONTEITH, J.L. Solar radiation and productivity in tropical ecosystems. Journal of Applied Ecology, v.9, p. 747-766, 1972.

MONTEITH, J.L.; ONG, C.K.; CORLETT, J.E. Microclimatic interactions by in agroforestry systems. Forest Ecology and Management, v.45, p. 31-44, 1991.

MOONEY, H.A.; GULMON, S.L. Environmental and evolutionary constraints on the photosynthetic characteristics of higher plants. In: SOLBRIG, O.T.; JAIN, S.; JOHNSON, G.B.; RAVEN, P.H. (Ed.). Topics in plant population biology. New York: Columbia University Press, 1979. p. 316-337.

MOONEY, H.A.; FIELD, C.; WILLIAMS, W.E.; BERRY, J.A.; BJÖRKMAN, O. Photosynthetic characteristics of plants of a Californian cool coastal environment. Oecologia, v.57, p. 38-42, 1983.

MORAIS, H.; MARUR, C.J.; CARAMORI, P.H.; RIBEIRO, A.M.A.; GOMES, J.C. Características fisiológicas e de crescimento de cafeeiro sombreado com guandu e cultivado a pleno sol. Pesquisa Agropecuária Brasileira, v. 38, n. 10, p. 11311137, 2003.

MUCHOW, R.C.; ROBERTSON, M.J.; PENGELLY, B.C. Radiation-use efficiency of soybean, mungbean and cowpea under different environmental conditions. Field Crops Research, v.32, p. 1-6, 1993.

MUETZELFELDT, R.I.; SINCLAIR, F.L. Ecological modeling of agroforestry systems. Forestry Abstracts. v.54, n.12, p.1103-1143, 1993. 
NAIR, P.K.R. Agroforestry systems in the tropics. Dordrecht: Kluwer Academic, 1989. $664 \mathrm{p}$.

NOBEL, P.S. Leaf anatomy and water use efficience. In: TURNER, N.C.; KRAMER, P.J. (Ed.). Adaptation of plants to water and high temperature stress. New York: Willey, 1980. p. 43-55.

NOBEL, P.S.; ZARAGOZA, L.J.; SMITH, W.K. Relation between mesophyll surface area, photosynthetic rate and illumination during development of leaves of Plectranthus parviflorus Henckel. Plant Physiology, v.55, p.1067-1070, 1975.

NUNES, M.A. Environmental effects on the stomatal and mesophyll regulation of photosynthesis in coffee leaves. Photosynthetica, v.22, p. 547, 1988.

NURBERG, I.; MYLIUS, S.; EDWARDS, J. DAVEY, C. Windbreak research in a South Australian cropping system. Australian Journal of Experimental Agriculture, v. 42, p. 781-795, 2002.

NUTMAN, F.J. Photosynthesis of coffee leaves under natural conditions. Annals of Botany, v. 1. n. 3, p. 353-367, 1937a.

NUTMAN, F.J. Studies of the physiology of Coffea arabica II. Stomatal movements in relation to photosynthesis under natural conditions. Annals of Botany, v. 1. n. 3, p. $681,1937 \mathrm{~b}$.

ONG, C.K. Alley cropping - ecological pie in the sky? Agroforestry Today, p. 8-11, July/ Sept. 1994.

ONG, C.K.; CORLETT J.E.; MARSHALL F.M.; BLACK, C.R. Principles of resource capture and utilization of light and water. In: ONG, C.K.; HUXLEY, P. (Ed.). Tree-crop interactions: a physiological approach. Wallingford: CAB International, 1996. cap. 4, p.73-158.

ONG, C.K.; CORLETT, J.E.; SINGH, R.P.; BLACK, C.R. Above and below-ground interactions in agroforestry systems. Forest Ecology and Management. 1991. v.45, p. $45-57$.

OSMOND, C.B.; BJÖRKMAN, O.; ANDERSON, D.J. Physiological processes in plant ecology. New York: Springer-Verlag, 1980 1v.

PACHEPSKY, L.B.; HASKETT, J.D.; ACOCK, B. An adequate model of photosynthesis. I. Parameterization, validation and comparison of models. Agricultural Systems, v.50, p. 209-225, 1996.

PATHAK, P.S.; GUPTA, S.K. Soil melioration role of Leucaena in the agroforestry system. In: INTERNATIONAL WORKSHOP ON AGROFORESTRY FOR RURAL NEEDS, New Delhi, 1987. Proceedings.

PENNING DE VRIES, F.W.T. System analysis and models of crop growth. In: PENNING DE VRIES, F.W.T.; VAN LAAR, H.H. (Ed.). Simulation of plant growth and crop production. Wageningen: PUDOC. 1982. p.9-19. (Simulation Monographs) 
PEREIRA, A.R. Mathematical modeling. Agricultural and Forest Meteorology. v.31, p.217-218, 1984.

PEREIRA, C.R. Análise do crescimento e desenvolvimento da cultura da soja sob diferentes condições ambientais. Viçosa, 2002. 282 p. Tese (Doutorado) Universidade Federal de Viçosa.

PINTO, L.F.G. Avaliação do cultivo da cana-de-açúcar em sistemas agroflorestais em Piracicaba, SP. Piracicaba, 2002. 116p. Tese (Doutorado) - Escola Superior de Agricultura "Luiz de Queiroz", Universidade de São Paulo.

RAMKRISHNA, Y.S. Forest microclimate and its importance in agroforestry. In: SHANKARNARAYAN, K.A. (ed.). Jodhpur: ICAR CAZRI, 1984. p. 9-12. (Monograph, 23).

RAO, M.R.; NAIR, P.K.R.; ONG, C.K. Biophysical interactions in tropical agroforestry systems. Agroforestry Systems, v.38, n.1/3, p.3-50, 1997.

RAO, Y.S.; MACDIKEN, K.G. Forewords. In: MELLICK, W.; RAO, Y.S.; MACDIKEN, K.G. (Ed.). Agroforestry in Asia and the Pacific. New Delhi: Rapa Publ., 1991. p. 1-2.

REIS, A.S. Zoneamento agroclimático para a cafeicultura em Pernambuco. Recife: IPA, 1972. 24 p. (Boletim Técnico, 52).

REYNOLDS, L.; ATTA-KRAH, A.N.; FRANCIS, P.A. Alley farming with livestock guidelines: humidity zone research site. Nigeria: International Live Stock Centre for Africa, $1988.30 \mathrm{p}$.

RIGHI, C.A. Interações ecofisiológicas acima e abaixo do solo em um sistema agroflorestal de seringueira (Hevea brasiliensis) e feijoeiro (Phaseolus vulgaris). Piracicaba, 2000. 130p. Dissertação (Mestrado) - Escola Superior de Agricultura "Luiz de Queiroz", Universidade de São Paulo.

RIZZINI, C.T.; HERINGER, E.P. Preliminares acêrca das formações vegetais e do reflorestamento no Brasil Central. Rio de Janeiro. Ed. Serviço de Informação Agrícola, Ministério da Agricultura, 1962.79 p.

ROBLEDO, A.J. Balanço de radiação solar em Coffea arabica L. variedade Catuaí e Bourbon Amarelo. Piracicaba, 1979. 68 p. Dissertação (Mestrado) - Escola Superior de Agricultura "Luiz de Queiroz", Universidade de São Paulo.

RUSSELL, G.; JARVIS, P.G.; MONTEITH, J.L. Absorption of radiation by canopies and stand growth. In: RUSSELL, G.; MARSHALL, B.; JARVIS, P.G. (Ed..). Plant canopies: their growth, form and function. Cambridge: Cambridge University Press, 1989. p. 21-40.

SÁ, T.D.A. Aspectos climáticos associados a sistemas agroflorestais: implicações no planejamento e manejo em regiões tropicais. In: CONGRESSO BRASILEIRO SOBRE SISTEMAS AGROFLORESTAIS, 1., Porto Velho, 1994. Anais. Colombo: EMBRAPA, 1994. v.1, p. 391-429. 
SAKAMOTO, C.M.; SHAW, R.S. Light distribution in field soybeans canopies. Agronomy Journal, v. 59, n.1, p. 7-9, 1967.

SAKURATANI, T. A heat balance method for measuring water flux in the stem of intact plants. Journal of Agricultural Meteorology, v. 37, p. 9-17, 1981.

SALISBURY, F.B.; ROSS, C.W. Plant physiology. 2.ed. Belmont: Wadsworth Publ., 1978. $422 \mathrm{p}$.

SAMPAIO, L.S. Radiação e crescimento de plantas jovens de açaí em sistemas agroflorestais. Piracicaba, 2003. 59 p. Tese (Doutorado) - Escola Superior de Agricultura "Luiz de Queiroz", Universidade de São Paulo.

SANCHEZ, P.A. Science in agroforestry systems. Agroforestry Systems, v.30, p. 5$55,1995$.

SCOTT, R.K.; WILCOCKSON, S.J. Application of physiological and agronomic principles to the development of the potato industry. In: HARRIS, P.M. (Ed.). The potato crop. New York: Chapman and Hall, 1978. p. 678-704.

SENTELHAS, P.C.; MARIN, F.R.; PEREIRA, A.R.; ANGELOCCI, L.R.; VILLA NOVA, N.A.; BARBIERI, V. Análise dos dados climáticos e do balanço hídrico climatológico de Piracicaba (1917-1997). Piracicaba: ESALQ, DFM 1998. 81p.

ŠESTÁK, Z. Leaf ontogeny and photosynthesis. In: JOHNSON, C.B. (Ed.). Physiological processes limiting plant productivity. London: Butterworths, 1981. p. 147-158.

SHEPPERD, W.D. An instrument for measuring tree crown width. Fort Collins: USDA Forest Service, 1973. 3 p. (USDA. Forest Service Research Note, RM 229).

SHIBLES, R.M.; WEBER, C.R. Leaf area, solar radiation interception, and dry mater production by various soybean planting patterns. Crop Science, v.6, p. 55-59, 1965.

SHOUBO, H.; GENSHEN, P.; RENJUN, G. Physiological and biochemical characteristics of tea plants interplanted with trees. In: ZHAOHUA, Z.; MANTANG, C. SHIJI, W.; YOUXU, J. (eds.) Agroforestry systems in China. Pequim: Chinese Academy of Forestry; IDRCC, 1991. p. 162-166.

SINCLAIR, F.; LAWSON, G. Special issue on agroforestry modeling. Agroforestry Forum. v.8, n.2, p.55, 1997.

SINGH, A.; SINGH, M. Effect of various stages of shifting cultivation on soil erosion from steep hill slopes. Indian Forester, v.16, n.2, p. 116-121, 1980.

SIONIT, N.; KRAMER, P.J. Effect of water stress during different stages of growth of soybean. Agronomy Journal, v.69, p. 274-278, 1977.

SOKAL, R.R.; ROHLF, F.J. Biometry: the principles and practices of statistics in biological research. New York: Freeman, 1995. 887p.

SQUIRE, G.R. The physiology of tropical crop production. London: CAB International, 1990. 236p. 
STIRZAKER, R.; LEFROY, E.; ELLIS, T. An index for quantifying the trade-off between drainage and productivity in tree-crop mixtures. Agricultural and Water Management, v. 53, p. 187-199, 2002.

STOCKLE, C.O.; KINIRY, J.R. Variability in crop radiation-use efficiency associated with vapour-pressure-deficit. Field Crops Research, v.25, p. 171-181, 1990.

SUTCLIFF, J.F. As plantas e a água. São Paulo: EDUSP, 1980. 67p.

TAIZ, L.; ZEIGER, E. Plant physiology. Redwood: The Benjamin/Cummings Publ., 1991. $565 \mathrm{p}$.

TREJO-CHADIA, J.E. Avaliação do método de balanço de calor na estimativa da transpiração em tomateiros, plantas de milho e mudas de limoeiro. Piracicaba, 1997. 75 p. Tese (Doutorado) - Escola Superior de Agricultura "Luiz de Queiroz", Universidade de São Paulo.

VALANCOGNE, C.; NASR, Z. Une methode de mesure du débit de séve brute dans des petits arbres par bilan de chaleur. Agronomie, n. 9, p. 609-617, 1989.

VIANELLO, R.L.; ALVES, A.R. Meteorologia básica e aplicações. Viçosa: UFV, Imprensa Universitária, 2000. 449 p.

VILLA NOVA, N.A.; SENTELHAS, P.C. Evapotranspiração máxima do feijoeiro, cv. Goiano precoce, em função do índice de área foliar e da evapotranspiração do tanque Classe A. In: REUNIÃO LATINO-AMERICANA DE AGROMETEOROLOGIA, 2., Florianópolis, 1999. Anais. Florianópolis: SBA, 1999. v.1, p.212-218.

VILLA NOVA, N.A.; ANGELOCCI, L.R.; COELHO, M.A.; MARIN, F.R.; RIGHI, C.A. Determinação da área foliar de árvores adultas de lima ácida 'Tahiti' e do índice de área foliar de um seringal com luxímetro de baixo custo. In: CONGRESSO NACIONAL DE IRRIGAÇÃO DE DRENAGEM, 13., Juazeiro, 2003. Anais. Juazeiro: Embrapa, 2003. (cd-rom).

VOLTAN, R.B.Q.; FAHL, J.J E CARELLI, M.L.C. Variação na anatomia foliar de cafeeiros submetidos a diferentes intensidades luminosas. Revista Brasileira de Fisiologia Vegetal, v.4, n.2, p. 99-105, dez. 1992.

WATSON, D.J. The dependence of net assimilation rate on leaf area index. Annals of Botany, v.22, p.37-54, 1958.

WEIBEL F.P.; VOS, J.A. de Transpiration measurements in apple trees: an improved stem balance heat method. Plant and Soil, v. 166, p. 203-217, 1994.

WILLEY, R.W.; REDDY, M. S. A field technic for separating above-and bellow interactions in intercropping and experiment with pearl millet groundnut. Experimental Agriculture, v.17, p. 257 - 264, 1981.

WILLIAMS, W.A.; LOOMIS, R.S.; LEPLEY, C.R. Vegetative growth of corn as affected by population density. 1. Productivity in relation to interception of solar radiation. Crop Science, v.5, p. 211-215, 1965. 
WILTSHIRE, J.J.J.; WRIGHT, C.J.; COLLS, J.J.; UNSWORTH, M.H. Effects of heat balance stem-flow gauges and associated silicone compound on ash trees, Agricultural and Forest Meteorology, v.73, p. 135-142, 1995.

YOUNG, A. Hypothesis for soil agroforestry research. Agroforestry Today, v. 1, n.1, p. 13-16, 1989.

YOUNG, A. Agroforestry for soil management. 2.ed. Wallingford: CAB International, 1997a. 320p.

YOUNG, A. The effectiveness of contour hedgerows for soil and water conservation. Agroforestry Forum, v.8, n.4, p.2-4, 1997b. 